\title{
THE DARK SIDE OF EFFICIENCY: JOHNSON V. M'TNTOSH AND THE EXPROPRIATION OF AMERICAN INDIAN LANDS
}

\author{
ERIC KADES ${ }^{\dagger}$
}

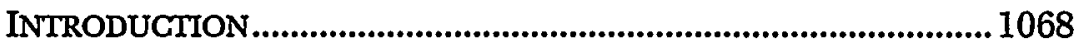

I. THE HISTORY OF JOHNSON V. M'INTOSH.................................1073

A. Land Title and Alienability in Early America.......................... 1073

B. The Purchases of the Illinois and the Wabash Land Companies...................................................1081

C. The Litigation of Johnson v. M'Intosh ................................. 1090

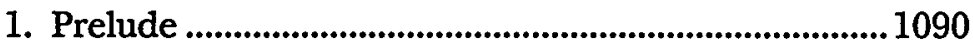

2. Supreme Court Arguments and Holdings.................. 1093

3. Marshall's Version of Indian Title.................................. 1096

4. Legal Basis for the M'Intosh Rule: Custom.................. 1098

II. EFFICIENT EXPROPRIATION ...............................................1103

A. Custom and the Efficiency Interpretation of M'Intosh ..............1106

1. Evolution of Efficient Customary Rules ..........................1106

2. Contrasting Efficiency with

Other Explanations of M'Intosh...................................1108

B. Governing European-Indian Relations:

Presenting a United Front ......................................................... 1110

1. United Front in Land Purchases ................................1110

2. The Bargaining Game...............................................1118

a. Bargaining "Tricks" Colorably

Consistent with Contract Law ...................................... 1119

b. Fraud, Overawing, and Threats.................................. 1124

c. Why the Indians Could Not Use Tricks and Threats ..... 1127

d. The Americans' Use of Both Acceptable Tricks and Unacceptable Threats.

† Associate Professor, Wayne State University Law School. Thanks to Douglas Allen, Kingsley Browne, Frank Buckley, Steve Calkins, Bob Ellickson, Peter Henning, Jim Krier, Mike McIntyre, Jack Mogk, Carol Rose, Sandra Van Burkleo, Vince Wellman, and $E d$ Wise, for both encouragement and very helpful comments. 
C. Explaining the Rarity of Fighting:

The Deadweight Loss of Fighting.

D. Altering the Terms of Trade: Natural Allies............................. 1141

1. Depopulation by Disease ..............................................1141

2. Game-Thinning.................................................... 1146

3. Understanding the Economic Impact of Game-Thinning.

E. Altering the Terms of Trade:

Legal Rules to Attract Settlers and Deal with Extermalities........ 1153

1. Attracting and Rewarding Settlers.............................. 1153

a. The Economics of Attracting and Rewarding Settlers.....1153

b. Legal Rules to Attract and Reward Settlers.....................1156

i. Compactness and the

Rectangular Survey System ...............................1156

ii. Special Programs for Special Abilities:

Military Bounties

iii. Requiring Improvements................................ 1163

iv. Disfavoring Large-Scale Speculation ................1164

v. Discounts to Attract the Masses........................1168

2. Negative Externalities of Lawless Settlers,

Speculators, and Traders.............................................. 1175

3. Positive Externalities of Trade....................................1183

F. Putting the Pieces Together: The Algorithm of

Efficient Expropriation.

G. Analogizing Efficient Conquest to Eminent Domain................. 1185

CONCLUSION. 


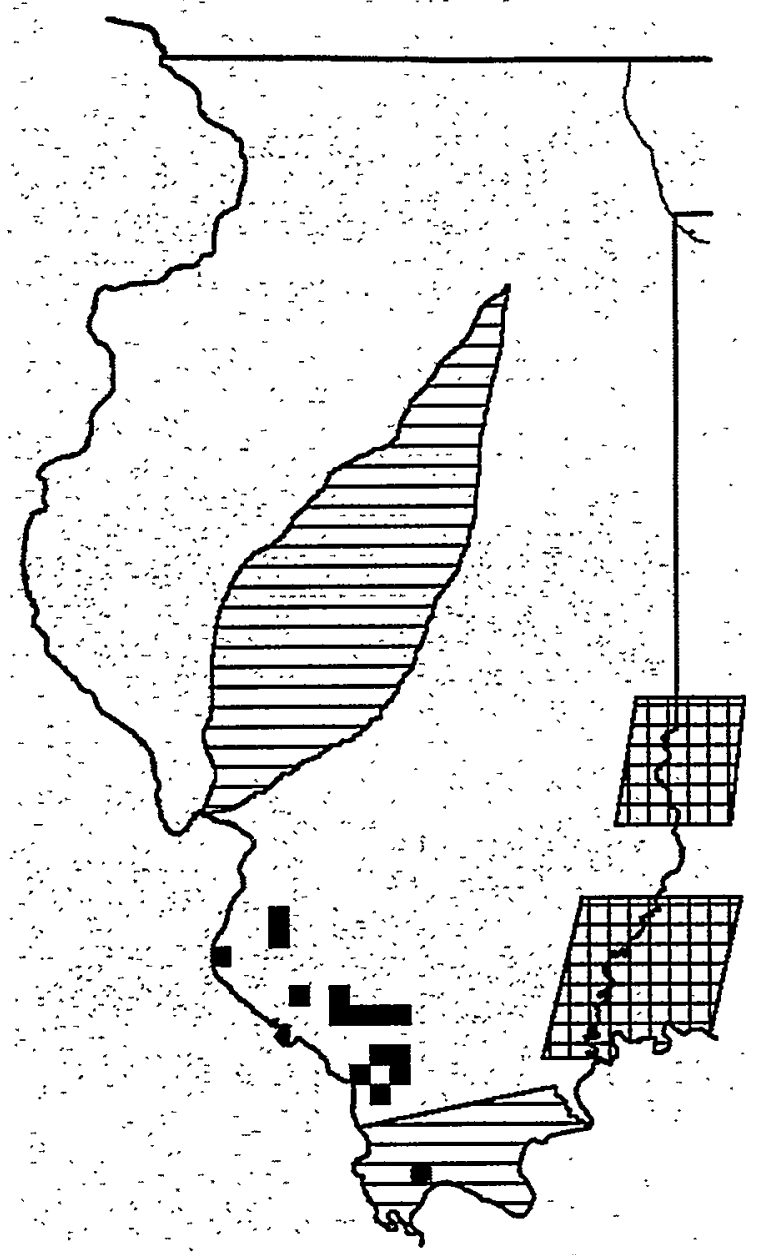

Claims in Johnson v. M'Intosh

\section{LEGEND}

Tracts Purchased by Illinois Company (1773)

Tracts Purchased by Wabash Company (1775)

Townships Containing McIntosh Purchases of 1815 (at issue in case)

Townships Containing McIntosh Purchases of 1819 (not at issue in case) 
The Spaniards were unable to exterminate the Indian race by those unparalleled atrocities which brand them with indelible shame, nor did they succeed even in wholly depriving it of its rights; but the Americans of the United States have accomplished this twofold purpose with singular felicity, tranquilly, legally, philanthropically, without shedding blood, and without violating a single great principle of morality in the eyes of the world. It is impossible to destroy men with more respect for the laws of humanity. ${ }^{1}$

\section{INTRODUCTION}

One of the most critical deprivations that the American Indians suffered at the hands of the United States was the loss of their lands. Within two centuries of the first European settlements in North America, the newcomers held title to almost every acre of the continent. At the root of most land titles in America today sits a federal patent. Government title, in turn, flows from "[t]he great case of Johnson $v$. M["]Intosh," which held that the United States has the exclusive right to extinguish Indians' interests in their lands, either by purchase or just war. M'Intosh was consistent with a long and uninterrupted line of statutes, regulations, and proclamations that barred private purchases of land from the Indians.

Most discussion of M'Intosh, and, more generally, of the larger process of expropriating North America from the Indians, has focused on normative questions about the relative evil or benevolence of the invading Europeans. De Tocqueville, contrasting Spanish "atrocities" with American legality and philanthropy, expressed the benevolent view that, unsurprisingly, was quite common in early America. E. de Vattel, a prominent eighteenth-century scholar of international law, noted with favor the American practice of buying lands even where, strictly speaking, the law did not require it:

[W] can not but admire the moderation of the English Puritans who were the first to settle in New England. Although they bore with them a charter from their sovereign, they bought from the savages the lands they wished to occupy. Their praiseworthy example was followed by

11 ALEXIS DE TOCQUEVILLE, DEMOCRACY IN AMERICA 355 (Phillips Bradley ed. \& Henry Reeve trans., Alfred A. Knopf, Inc. 1945) (1835).

2 Tee-Hit-Ton Indians v. United States, 348 U.S. 272, 279 (1954) (citing Johnson v. M'Intosh, 21 U.S. (8 Wheat.) 543 (1823)). In the M'Intosh opinion itself, Chief Justice Marshall adverted to the "magnitude of the interest in [this] litigation." M'Intosh, 21 U.S. (8 Wheat) at 604 . William McIntosh spelled and signed his last name with a " $\mathrm{c}$ " instead of an apostrophe, yet the Supreme Court used an apostrophe. 
William Penn and the colony of Quakers that he conducted into Pennsylvania.

Other commentators, while also maintaining that Europeans expropriated with the best of intentions, at least tried to come to terms with the undeniably detrimental effect on Indians. "No government ever entertained more enlightened and benevolent intentions toward a weaker people than did that of the United States toward the Indian, but never in history, probably, has a more striking divergence between intention and performance been witnessed."

Despite this failure to translate intent into effective action, leading scholars of this century have concurred with this sympathetic view. Felix Cohen, the founder of American Indian law as a distinct and scholarly field of study, noted that America paid for almost every square foot of the nation. He thus argued that "[w]e are probably the one great nation in the world that has consistently sought to deal with an aboriginal population on fair and equitable terms. We have not always succeeded in this effort but our deviations have not been typical." Francis Paul Prucha, a leading historian of relations between the United States and the Indians, has argued that treaties and statutes evidence a sincere desire to protect Indian rights. ${ }^{6}$ Another historian, Don Russell, after debunking the myth that Indian massacres played a significant role in expropriating the continent by exterminating its aboriginal inhabitants, argued that the United States behaved with at least relative humanity. "Much of world history tells of the movements of peoples that infringe on other peoples. Rarely have the infringed upon been treated with more consideration and humaneness than was the American Indian."

The opposite view, that European laws and practices amounted to a patently immoral land-grab, dates back at least to the years immedi-

${ }^{3} 3$ E. DE VATTEL, LE DROIT DES GeNS, OU PRINCIPES DE LA LOI NATURELIE, APPLIQUÉS À LA CONDUITE ET AUX AFFAIRES DES NATIONS EI DES SOUVERAINS [LAW OF NATIONS OR THE PRINCIPLES OF NATURAL LAW APPIIED TO TFE CONDUCT AND TO THE AFFAIRS OF NATIONS AND OF SOVEREIGNS) 85-86 (Charles G. Fenwick trans., Oceana Publications, Inc. 1964) (1758).

${ }^{4}$ MILO MILTON QuAIFE, GHICAGO AND THE OLD NORTHWEST, 1673-1835, at 179 (1913).

${ }^{5}$ Felix S. Cohen, Original Indian Title, 32 MINN. L. REV. 28, 34 (1947).

6 See Francis Paul Prucha, american indian Policy in the formative Years: THE INDIAN TRADE \& INTERCOURSE ACTS, 1790-1834, at 248 (1962) ("For [the Indian policy of the United States] we must turn to the treaties made with the Indians, which uniformly guaranteed Indian rights ....").

${ }^{7}$ Don Russell, How Many Indians Were Killed?, AM. W.,July 1973, at 42, 63. 
ately following the decision in M'Intosh. Although Justice Joseph Story signed on to Chief Justice Marshall's unanimous opinion in the case, in a speech given five years later he argued that the case violated both "natural law and moral right." A later monograph labeled the opinion as "imperialism" and cast the result as facially immoral:

[A]bove all, [M'Intosh] involved a flat question of right and wrong. It was a decision which seems to have altogether ignored property rights which had solemnly vested.... We are then to inquire whether or not the conscience of the world will today respond affirmatively to the proposition that discovery and conquest alone give a title as against owners and occupants of property ... whether, in a word, that which is morally wrong can be legally and politically right.

A growing number of scholars, reexamining the historical record from the Indian perspective, have cast M'Intosh and the larger process of expropriating Indian lands in even darker terms. A particularly bleak account of European treatment of the Indians observes that those "reaching for illicit power customarily assume attitudes of great moral rectitude to divert attention from the abandonment of their own moral standards of behavior.... All conquest aristocracies have followed such paths. It would be incredible if ours had not." ${ }^{\text {10 }}$ Another scholar, Vine Deloria, avers that "Indians have not accepted the mythology of the American past which interprets American history as a sanitized merging of diverse peoples to form a homogeneous union. The ... abuses of the past and present [are] too vivid, and the memory of freedom [is] too lasting." ${ }^{\text {"1 }}$

After a thorough study of the intellectual antecedents to the opinion, a recent work classifies M'Intosh as part of a

discourse of conquest, which denies fundamental human rights and selfdetermination to indigenous tribal peoples... . [This discourse asserts] the West's lawful power to impose its vision of truth on non-Western peoples through a racist, colonizing rule of law.

... [T] he United States acquired a continent "in perfect good faith" that its wars and acts of genocide directed against Indian people accorded with the rule of law.

${ }^{8}$ R. KENT NEWMYER, SUPREME COURT JUSTICE JOSEPH STORY: STATESMAN OF THE OLD REPUBLIC 213 (1985).

${ }^{9}$ GEORGE BRYAN, THE IMPERIALISM OF JOHN MARSHALL: A STUDY IN EXPEDIENCY iii (1924).

${ }^{10}$ Francis Jennings, The Invasion of America: Indians, Colonialism, AND the CANT OF CONQUEST iX (1975).

${ }^{11}$ VINE DELORIA, BEHIND THE TRAIl OF BROKEN TREATIES: AN INDIAN DECLARATION OF INDEPENDENCE 2 (1974). 
... [T] $]$ he West's archaic, medievally derived legal discourse respecting the American Indian is ultimately genocidal in both its practice and its intent.

For both sides of this debate, law plays a central role. Those with a dark view of the process of expropriation argue that European settlers used (or perhaps more accurately, abused) laws either with specific intent to take land and exterminate the aboriginal population, or with deliberate indifference to these inevitable results of their policies. Observers who view European actions as relatively benevolent insist that legal rules softened the process of expropriation.

This Article makes no attempt to resolve this long-running and well-known normative debate. Moreover, neither view is consistent with even the most basic facts in the legal and historical record. Massacres, and even battles, were quite rare in the process of expropriating Indian lands-a fact difficult to harmonize with a theory of intentional genocide. On the other hand, it is hard to reconcile a benevolent view of the expropriation process with the end result-the knowing and intentional expropriation of a continent accompanied by the destruction of tribe after tribe.

This Article presents a view more consistent with the somewhat schizophrenic legal and historical record. Drawing on law and economics, it explains the process of expropriating Indian lands in terms of minimizing the costs, broadly defined (for example, value of lives, risks borne, and time spent on unproductive warfare), to the European colonizers. Simply put, customs and legal rules promulgated by colonial and later American courts and legislatures promoted not simply expropriation (right or wrong), but efficient expropriation. The thesis of this Article is that colonists established rules to minimize the costs associated with dispossessing the natives. If it had been cheaper to be more brutal, then Europeans would have been more brutal. Such brutality, however, was not cheap at all.

Likewise, if it had been cheaper to show more humanity, the Europeans would have exhibited more, such as extending Indians full rights to sell (or keep) their land. Such a legal rule, however, would have been far from cheap. Johnson $v$. M'Intosh was an essential part of the regime of efficient expropriation because it ensured that Europeans did not bid against each other to acquire Indian lands, thus keep-

${ }^{12}$ ROBERT A. WILLIAMS JR., THE AMERICAN INDIAN IN WESTERN LEGAL. THOUGHT: THE DISCOURSES OF CONQUEST 325-26 (1990) (citation omitted). 
ing prices low. ${ }^{13}$ The M'Intosh rule was neither the beginning nor the end of the means by which Europeans obtained American soil at minimal cost. Part II of this Article places the rule of M'Intosh in broader context. It explains why wars of conquest were unappealing and rare, and how disease and the destruction of the Indians' stocks of wild game played a much larger role in efficient expropriation. ${ }^{14}$ It then explains how legal rules channeled settlement to maximize the effect of these "natural allies" and shows how the Europeans' greater ability to maintain a united front yielded a set of tools for efficient expropriation, from M'Intosh to powerful advantages in negotiation. ${ }^{15}$

Despite some disagreements, this Article's law and economics interpretation of American-Indian relations owes a significant intellectual debt to recent articles by Terry Anderson and Fred McChesney, ${ }^{16}$ and by Douglas Allen. ${ }^{17}$ Anderson and McChesney convincingly demonstrate that the United States took few acres by direct force, arguing that the price paid for Indian lands depended on what each side expected to happen in the event of conflict. This Article questions Anderson and McChesney's dichotomy between taking lands by raid (force) and by trade, suggesting instead that there was a continuum of techniques between these two poles. The United States mixed and matched techniques from both extremes in order to minimize the cost of Indian lands. Allen argues that giving away land, or at least subsidizing settlement, under the Homestead Acts and their precursors, was a least-cost way of dealing with hostile Indians-settlers formed a rough, ready, and cheap border militia. ${ }^{18}$ This Article builds on Allen's work by demonstrating the key role settlers played in weakening Indian resistance by spreading disease and thinning game.

In addition to supplementing these earlier works, this Article examines other legal rules that enabled the cheap expropriation of Indian lands. These factors include government coordination of set-

${ }^{13}$ See discussion infra Part II.A (contrasting the efficiency interpretation of $M^{\prime}$ Intosh with other explanations).

${ }^{14}$ See discussion infra Part II.D (examining the role played by the Europeans' "natural allies" in permitting them to efficiently expropriate Indian land).

${ }_{15}$ See discussion infra Part II.E (discussing how the Europeans' legal rules encour. aged private actions that helped expropriate Indian land).

${ }^{16}$ Terry L. Anderson \& Fred S. McChesney, Raid or Trade? An Economic Model of Indian-White Relations, 37 J.L. \& ECON. 39 (1994).

${ }^{17}$ Douglas W. Allen, Homesteading E' Property Rights; or, "How the West Was Really Won,"34J.L. \& ECON. 1 (1991).

${ }^{18}$ See id. at 2 (describing the benefits of the Homestead Act and rejecting arguments that the Act was a mistake). 
tlers' movements, legal rules that overcame a natural inertia in the westward expansion (characterized by the desire to let others go first and bear the costs of first settlement), the federal government's general reluctance to distribute land through large land companies, and perhaps most importantly, the competition-stifling rule of Johnson $v$. M'Intosh.

Before tracing out this theory of efficient expropriation, however, Part I presents a brief history of "[t]he great case of Johnson $v$. M'Intosh." ${ }^{\prime 9}$ There are two reasons for this digression. First, as a leading Supreme Court case, the background to M'Intosh is of interest in and of itself. Part I presents material from a variety of sources that neither historians nor legal scholars have examined. The record is full of surprises, from the fact that the (victorious) defendants' purchases may well have been illegal, to the likelihood that the case was feigned. ${ }^{20}$

The second reason for presenting the history of M'Intosh is that it provides a nucleus of historical facts (for example, that disease had decimated the Indian sellers of the lands in question), background legal rules (including the long history of legislative strictures on purchasing land from Indians), and archetypal characters (such as speculating land companies of the early republic) that helps explain the process of efficient expropriation. The legal rule of M'Intosh is but one piece in the large puzzle of efficient expropriation of Indian land; characters from every stage of the case's history provide insights into the other pieces and how they all fit together.

\section{THE HISTORY OF JOHNSON V. M'INTOSH}

\section{A. Land Title and Alienability in Early America}

Generally, European colonists employed European real property law to define their rights in American lands. Two complications, however, created the need for additional rules. First, competing European sovereigns had to establish rules to deal with conflicting claims amongst themselves to American lands. Second, the European colonizers had to decide what rights, if any, Indians had to their own lands.

${ }^{19}$ For a more detailed history of the case, see Eric Kades, The Great Feigned Case of Johnson v. M'Intosh, 19 L. \& HIST. REV. (forthcoming 2001).

${ }^{20}$ See discussion infra Part I.C (providing historical background for the M'Intosh litigation). 
The simultaneous British, French, Dutch, Spanish, and even Swedish explorations and colonization of North America inevitably led to land disputes.

[A]s they were all in pursuit of nearly the same object, it was necessary, in order to avoid conflicting settlements, and consequent war with each other, to establish a principle, which all should acknowledge as the law by which the right of acquisition, which they all asserted, should be regulated as between themselves. This principle was, that discovery gave title to the government by whose subjects, or by whose authority, it was made, against all other European governments, which title might be consummated by possession.

As with many rules of international law, competing nations often disregarded this discovery rule when it did not suit their purposes, yet the rule did serve to avoid at least some conflicts.

It is important to note that, strictly speaking, this discovery rule applied only among European nations ("regulated as between themselves"). Some commentators have used the term "discovery rule" or "discovery doctrine" to describe the rules that the various European sovereigns established for defining Indian land rights, ${ }^{22}$ such as the M'Intosh rule that the sovereign alone could purchase land from the natives. Milner Ball cogently explains why this is inconsistent with Marshall's approach:

The theory [of $M^{\prime}$ 'Intosh] sets out two different relationships: one among European claimants to the New World, the other between each of the European claimants and the Indian inhabitants. As among the Europeans, the doctrine of discovery obtained. As between European and Indian nations, each relationship was to be separately regulated. ${ }^{23}$

${ }^{21}$ Johnson v. M'Intosh, 21 U.S. (8 Wheat.) 543, 573 (1823).

22 See Nell Jessup Newton, At the Whim of the Sovereign: Aboriginal Title Reconsidered, 31 HASTINGS L.J. 1215, 1222-24 (1980) ("[T]he doctrine of discovery permitted the sovereign alone to extinguish Indian title ...."). The statement can be corrected by adding the italicized language: "the doctrine of discovery permitted the sovereign alone to establish the rules that would govern how to extinguish Indian title."

${ }_{23}^{3}$ Milner S. Ball, Constitution, Court, Indian Tribes, 1987 AM. B. FOUND. RES. J. 3, 24; see also M.F. LINDLEY, THE ACQUISITION AND GOVERNMENT OF BACKWARD TERRITORY IN INTERNATIONAL LAW 29 (Negro Universities Press 1969) (1926) (noting that European nations claimed that discovery rights provided dominion over Indian territory and priority of discovery determined which nation had ownership); Howard R. Berman, The Concept of Aboriginal Rights in the Early Legal History of the United States, 27 BUFF. L. REV. $637,644-45$ (1978) (defining the doctrine of discovery as the "organizing principle through which the European nations articulated claims against each other"); J.Youngblood Henderson, Unraveling the Riddle of Aboriginal Tille, 5 AM. INDIAN L. REV. 75, 90 (1977) ("Discovery ... was a distributional preference by which the Europeans agreed to divide up entitlements to acquire tribal lands."); John Hurley, Aboriginal Rights, the 
Thus, the discovery doctrine did not apply, at least directly, to European-Indian relations.

Confusion about this two-level doctrine-(1) the discovery rule regulating inter-European disputes, and (2) rules regulating European-Indian disputes-may be due in part to the following dense passage in Chief Justice Marshall's opinion:

The exclusion of all other Europeans, necessarily gave to the nation making the discovery the sole right of acquiring the soil from the natives, and establishing settlements upon it. It was a right with which no Europeans could interfere. It was a right which all asserted for themselves, and to the assertion of which, by others, all assented.

Describing the "sole right of acquiring the soil" as a necessary result of the discovery rule is misleading. Marshall meant that a discovering nation could exclude other nations under the first level, the inter-European discovery rule. The discovery rule did not dictate which rule each sovereign chose at the second level when defining rights visa-vis the Indians. Thus, the quoted passage did not mean that each sovereign had to bar its own citizens from making private purchases of land from the Indians. This was merely the particular second-level rule Marshall found that America and its predecessors adopted. Indeed, contrary to the American rule explicated in M'Intosh, it appears that France at times permitted its colonists to purchase lands directly from the Indians. ${ }^{25}$

Marshall's very next sentence makes clear the distinction between the discovery rule as level one, and whatever rules each nation decided to establish as level two: "Those relations which were to exist

Constitution and the Marshall Court, 17 REvUE JURIDIQUE THEMIS 403, 418 (1982-1983) (discussing the significance of M'Inlosh and the principle of discovery). Berman perceptively notes the one linkage between the discovery doctrine and relations with the tribes: "With the single exception of the right of alienability of land, the original, indeed aboriginal, sovereignty of the Indian nations is unimpaired by, and not included in, the concept of discovery." Berman, supra, at 650 .

${ }^{24}$ M'Intosh, 21 U.S. (8 Wheat.) at 573.

25 "[A]t Cahokia [in French-governed Illinois, prior to 1763] there were several cases of direct purchase by individuals from the Indians, [although] the practice was not [common], for the representatives of the government granted land freely, without formality, and without reservations .... CLARENCE WALWORTH ALVORD, THE ILINNOIS COUNTRY, 1673-1818, at 206 (Univ. of Ill. Press 1987) (1920). William Murray, the principal field agent of the land companies that bought the tracts at issue in M'Inlosh, consulted French records, older Indian leaders, and French inhabitants before negotiating with the tribes. His research showed that "the lands held for the use of garrisons, or held by the inhabitants, originated from cessions on grants obtained for a valuable consideration from the native Indians." Introduction to AN ACCOUNT OF THE PROCEEDINGS OF THE IIIINOIS AND OUABACHE LAND COMPANIES 5 (Philadelphia, William Duane 1803) [hereinafter ACCOUNT OF PROCEEDINGS] (emphasis added). 
between the discoverer and the natives, were to be regulated by themselves [(level two)]. The rights thus acquired being exclusive, no other power could interpose between them [(level one, the discovery rule) ]. ${ }^{26}$

From the beginning, English government in the New World refused to recognize the Indians as true title holders. Even during the first years of colonization, when they were no military match for the local tribes and indeed depended on their charity to survive, Virginia's earliest settlers began to articulate a theoretical basis to deny Indian title and thus expropriate tribal lands.

"Some affirm, and it is likely to be true, that these savages have no particular propriety in any part of parcel of that country, but only a general residency there, as wild beasts in the forest; for they range and wander up and down the country without any law or government, being led only by their own lusts and sensuality. There is not meum and tuum [mine and thine] amongst them. So that if the whole land should be taken from them, there is not a man that can complain of any particular wrong done unto him."

In the eyes of the Puritans, hunter-gatherers were not really occupants of their lands. "God had intended his land to be cultivated and not to be left in the condition of "that unmanned wild Countrey, which they [the savages] range rather than inhabite."'28 James Monroe, as President, more than once voiced the same theme. "[T]he hunter or savage state requires a greater extent of territory to sustain it, than is compatible with the progress and just claims of civilized life, and must yield to it." "[T] he earth was given to mankind to support the greatest number of which it is capable, and no tribe or people have a right to withhold from the wants of others more than is necessary for their own support and comfort. ${ }^{30}$

Common settlers, unsurprisingly, agreed with these sentiments, and invoked egalitarian, leveling arguments to explain why the landrich Indians should be compelled to share the wealth. For example, squatters on Chickasaw land successfully protested eviction that would

${ }^{26}$ M'Intosh, 21 U.S. (8 Wheat.) at 573.

${ }^{27}$ WIILIAMS, supra note 12, at 211 (quoting Robert Gray, a popular Puritan preacher).

${ }^{28}$ JENNINGS, supra note 10 , at 80 (quoting 4 SAMUEL PURCHAS, HAKIUYTUS POSTHUMUS OR PURCHAS HIS PILGRIMES 1814 (London, 1625)).

${ }^{29}$ PRUCHA, supra note 6, at 227 (quoting Letter from President James Monroe to Andrew Jackson (Oct. 5, 1817)).

30 A COMPIIATION OF THE MESSAGES AND PAPERS OF THE PRESTDENTS, 1789-1897, at 16 (James D. Richardson ed., 1896). 
"bring many women and children to a state of starvation mearly to gratify a heathan nation Who have no better right to this land than we have ourselves and they have by estemation nearly 100000 acres of land to each man of their nation.".31

A funny thing happened on the way to acquiring Indian lands. In spite of these oft-repeated justifications for simply taking Indian lands, colonists very early on began purchasing tracts instead of simply grabbing them (or trying to). This soon became official policy. The New England Company instructed its colonists in 1629 that "[i]f any of the Savages pretend Right of Inheritance to all or any Part of the land in our Patent . . . purchase their claim in order to avoid the least Scruple of Intrusion. ${ }^{32}$ When the Crown began to exercise more direct oversight of the colonies in the $1660 \mathrm{~s}$, it reiterated this principle. There was one instance in which outright expropriation was permissible: "just" wars, that is, defensive wars. ${ }^{33}$ Conquest in New England, however, remained very much the exception. The bottom line is that

contrary to the common belief that the Indians were ruthlessly deprived of their land, almost every part of [Massachusetts] that came to be inhabited by the whites was purchased from the Indians, except the areas that were either acquired by conquest or, like Salem and Boston, never claimed by the Indians, because of depopulation by epidemics. ${ }^{34}$

The pattern of European land acquisition in New England-purchases punctuated by rare conquests-repeated itself across the rest of the continent. The United States paid over $\$ 800$ million for Indian lands. ${ }^{35}$ According to Congress, the United States exercised the right of conquest only once, and then half-heartedly. ${ }^{36}$

${ }^{31}$ Petition to the President and Congress by Intruders on Clickasaw Lands (Sept. 5, 1810), reprinted in 6 THE TERRTIORIAI PAPERS OF THE UNITED STATES 106, 107 (Clarence Edwin Carter ed., 1938) [hereinafter TERRITORIAL PAPERS].

${ }^{32}$ JOEL N. ENO, THE PURITANS AND THE INDIAN LANDS 1 (1906).

93 YASUHIDE KAWASHIMA, PURTTAN JUSTICE AND THE INDIAN: WHITE MAN's LAW IN MASSACHUSETTS, 1630-1763, at 50 (1986).

${ }^{34}$ Id. at 51. See infra Part II.D.1 for a discussion of the important role epidemics played in breaking down Indian resistance to European colonization.

${ }_{35}$ See Cohen, supra note 5, at 45-46 (implying that Indian land purchases were fair to the extent that substantial federal funds were appropriated for purchases).

${ }^{36}$ The Commissioner of Indian Affairs in 1872 stated that:

Except only in the case of the Indians in Minnesota, after the outbreak of 1862, the United States Government has never extinguished an Indian title as by right of conquest; and in this latter case the Government provided the Indians another reservation, besides giving them the proceeds of the sales of the lands vacated by them in Minnesota.

Id. at 37 n.20 (quoting Report of the Commissioner of Indian Affairs for 1872). 
While Europeans recognized some Indian interest in land, they never "granted" the tribes all the sticks in the common-law bundle of property rights; in particular, colonists consistently narrowed or entirely denied the Indians' power to sell land. First, while Indians formally had the power to refuse to sell, ${ }^{37}$ in reality this was not an option. ${ }^{38}$ Second, European sovereigns asserted the right to sell Indian land to their citizers before purchasing from the Indians. Such a purchaser took title "subject only to the Indian right of occupancy," but otherwise had a full fee interest. Combined with the exclusive right to purchase Indian lands (or conquer the tribe), discussed in the following subsection, this created a novel and peculiar "bifurcated title." UItimate title resided with the European sovereign or its grantee, while the Indian occupants retained "Indian title" until they sold, or were otherwise relieved of their lands.

The facts of M'Intosh, discussed in Part I.C.1, present a conundrum that can arise under this bifurcated title regime: if the Indians sold to $Y$ while the Crown or the United States sold to $X$, who owned the land, $X$ or $Y$ ? Given the superiority that colonizers assigned to their title, it comes as no surprise that $X$ had title as against $Y$. The colonies, the British government, and the United States achieved this result by the same rule. They barred anyone but themselves from purchasing lands from the Indians. ${ }^{40}$ While most of the property rules discussed thus far involve European-Indian relations, this stricture was a regulation made by colonists, directed at only colonists. That said, this Article argues, in Part II.B, that the rule profoundly harmed the Indians.

Cohen cites the Report as observing, however, that " $[\mathrm{i}] \mathrm{t}$ is not to be denied that wrong was often done in fact to tribes in the negotiation of treaties of cession. The Indians were not infrequently overborne or deceived." Id. Part II infra discusses how the United States was able to coerce and deceive the Indians, and why such an approach was more attractive than conquest.

${ }^{37}$ See President Thomas Jefferson, Speech to Tribes (Apr. 22, 1808), quoted in Dwight L. Smith, Indian Land Cessions in the Old Northwest, 1795-1809, at 213-14 (1949) (unpublished Ph.D. dissertation, Indiana University (Bloomington)) (on file with author and the Universily of Pennsylvania Law Review) ("II]n all these things... you have been free to do as you please, your lands are your own ... to keep or sell as you please ... you are always free to say 'no,' and it will never disturb our friendship for you.").

${ }^{38}$ See infra Part II.B (describing how U.S. policy made the Indians' option to sell practically useless).

${ }^{39}$ Johnson v. M'Intosh, 21 U.S. (8 Wheat.) 573, 574 (1823).

40 The French apparently did not adopt such a rule and recognized private purchases of Indian lands. See supra note 25 and accompanying text (discussing France's policy toward its settlers regarding land purchases). 
The universal and repeated enactment of laws barring purchases of land by private citizens from the Indians attests to the importance that Britain, its colonies, and later the United States attached to this rule. In colonial New England, "[i]t is a reasonable generalization to say that land purchases from Indians were a governmental monopoly." Massachusetts apparently adopted the first such official law in $1634^{42}$ and repeatedly enacted similar measures. ${ }^{43}$ As late as 1760 , Massachusetts publicized the law and empowered local officials to enforce it at colonial expense. ${ }^{44}$ No later than 1672, Connecticut's General Court enacted a similar measure. ${ }^{45}$ Almost every colony adopted such measures as soon as they began purchasing significant amounts of Indian land. ${ }^{46}$ Successive British and American governments

${ }^{41}$ James Warren Springer, American Indians and the Law of Real Property in Colonial New England, 30 AM. J. LEGAL HisT. 25, 35-36 (1986) (collecting cites to colonial statutes barring private purchases of Indian lands).

${ }^{42}$ See I RECORDS OF THE GOVERNOR \& COMPANY OF THE MASSACHUSETTS BAY IN NEW ENGLAND 112 (photo. reprint 1968) (Nathaniel B. Shurtleff ed., Boston, William White 1853) (reprinting a law that prohibited purchasing land from the Indians without the permission of the court).

${ }^{13}$ See KAWASHIMA, supra note 33, at 53 (explaining that later versions included harsh penalties for mere attempts to buy land directly from Indians, including fines equal to double the value of the land or imprisonment for six months).

44 See 4 The Acts and Resolves, PUblic and Private, of the Province of the MASSACHUSETTS BAY: TO WHICH ARE PREFIXED THE CFIARTERS OF THE PROVINCE 369 (Boston, Wright \& Potter Printing Co. 1890) [hereinafter ACTS AND RESOLVES] (reprinting a 1760 law that authorized and empowered named state agents to prosecute any persons who purchased land from the Indians).

${ }^{15}$ See THE EARLIEST LAWS OF THE NEW HAVEN AND CONNECTICUT COLONIES, 1639 1673, at 112 (John D. Cushing ed., 1977) (reprinting a 1672 Colony of Connecticut law prohibiting the purchase of land from the Indians).

${ }^{46}$ See id.; 1 THE EARLIEST PRINIEd LAWS OF THE PROVINCE OF GeORGIA, 1755-1770, at 17-18 (John D. Cushing ed., 1978) (reprinting a 1758 Act prohibiting Georgia citizens from purchasing lands from and trading with the Indians without license); 4ACTS AND RESOLVES, supra note 44, at 369 (reprinting a 1760 Act giving certain Massachusetts officials the right to prosecute all persons who have purchased, or purchase in the future, lands from the Indians); 3 KENT's COMMENTARIES *396 (1873) (describing a similar 1644 Maryland measure); ACTS AND LAWS OF NEW HAMPSHIRE, 1680-1726, at 162 (John D. Cushing ed., 1978) (reprinting "An Act to Prevent and Make Void Clandestine and Illegal Purchases of Land from the Indians," passed in 1719); KENT'S COMMENTARIES, supra, at $* 39495$ (describing a similar 1682 New Jersey statute); KENT's COMMENTARIES, supra, at *385 (describing New York's measures at preventing illegal Indian land acquisition); 1 THE EARLIEST PRINTED LAWS OF NORTH CAROLINA, 1669-1751, at 38 (John D. Cushing ed., 1978) (reprinting a 1715 law prohibiting the purchase of land from the Indians); 4 THE STATUTES AT LARGE OF PENNSYLVANIA FROM 1682 To 1801, at 154-56 (James T. Mitchell \& Henry Flanders eds., n.p., Clarence M. Busch 1897) (reprinting "A Supplementary Act to an Act Against Buying Land of the Natives," passed in 1729); THE STATUTES AT LARGE OF SOUTH CAROLINA 526 (Thomas Cooper ed., 1836) (reprinting a 1739 statute making land conveyances from the Indi- 
adopted similar measures. ${ }^{47}$

The longstanding rule against private purchases is important for two reasons. First, it makes the holding of M'Intosh (reaffirming the rule against private purchases from the Indians) seem predictable; moreover, it lays the foundation for the novel argument that custom forms the central ground for Chief Justice Marshall's opinion. ${ }^{48}$ Second, the rule makes perfect sense as a tool of efficient expropriation of Indian lands. Universal enactment and strict enforcement of the M'Intosh rule support the least-cost expropriation thesis presented in Part II. ${ }^{49}$

ans to private persons void); 10 THE STATUTES AT LARGE: BEING A COLLECTION OF ALL THE LAWS OF VIRGINIA 97 (William Waller Hening ed., Richmond 1822) (1619) [hereinafter STATUTES AT LARGE OF VIRGINIA] (reprinting law on purchasing lands from "natives").

${ }^{47}$ See Act of Mar. 3, 1799, ch. 46, § 12, 1 Stat. 743, 746 (invalidating any sale of land by the Indians unless executed under treaty); Act of May 19, 1796, ch. 30, § 12, I Stat. 469, 472 (same); Act of Mar. 1, 1793, ch. 19, \& 8, 1 Stat. 329, 330 (same); Act of July 22, 1790 , ch. 33, \& 4, 1 Stat. 137, 138 (same); 24 JOURNALS OF THE CONITNENTAL CONGRESS 264 (1783) (same); 25 id. at 602 (same); Robert N. Clinton, The Proclamalion of 1763: Colonial Prelude to Two Centuries of Federal-State Conflict over the Management of Indian Affairs, 69 B.U. L. REv. 329, 356-57 (1989) (explaining that the Proclamation of 1763 barred private purchase of Indian lands). These statutes illustrate the United States's repeated barring of private purchases of Indian lands. Congress worded the later statutes quite broadly, criminalizing the act of negotiating ("treating") with the Indians for land, "directly or indirectly." 1 Stat. at 472; 1 Stat. at 330.

${ }^{48}$ See infra Part I.C.4 (describing the custom-based rationale behind the M'Intosh decision).

${ }_{49}$ The long and uninterrupted pedigree of the rule against private purchases raises a difficult question. Why did land speculators (such as the plaintiffs in M'Intosh) make purchases in the face of a seemingly clear legal refusal to recognize title rooted in Indian deeds? Many speculators, including those whose purchases from the Indians eventually precipitated the M'Intosh case, felt emboldened to engage in such transactions based in part on the Camden-Yorke Opinion. The Camden-Yorke Opinion was a peculiar legal opinion letter originally written by British Attorney General Charles Pratt (who later became Lord Camden) and Solicitor General Charles Yorke that affirmed the right of individuals to buy land from rajahs in British India. A slightly altered version, not limited to India (it is not clear if the original authors, or others, made the alterations), found its way to America no later than 1773. See Jack M. Sosin, The Yorke-Camden Opinion and American Land Speculators, 85 PA. MAG. HIst. \& BIOGRAPHY 38, 42-43 (1961) (describing historians' conflicting views on how this opinion came into the hands of American colonists).

As the later actions of many of the speculators indicate, they may have planned from day one to obtain ex post legislative action to except them from the laws that would void their titles. The incredible size of their claims, often in the millions of acres, provided a ready source of consideration with which to bribe legislators. Finally, anticipation of political change may have motivated the marked increase in private purchases from the Indians in the 1770s. The storm clouds of the impending American Revolution apparently led some speculators to believe that the British rule against purchases from Indians might be trumped by other considerations. "Should a revolution occur, Henderson [head of the Transylvania Company and Daniel Boone's spon- 


\section{B. The Purchases of the Ilinois and the Wabash Land Companies}

The plaintiffs in M'Intosh claimed lands under Indian deeds obtained before the Revolutionary War by two closely related land ventures, the Illinois Land Company and the Wabash Land Company. The Illinois Company arose out of the Indian trading and troop provisioning activities of a group of prominent Philadelphia merchants led by David Franks and the Gratz brothers, Bernard and Michael. Their partner and agent in Illinois, William Murray, successfully convinced the merchants to branch out from trade into land speculation. ${ }^{50}$ Murray arrived at the British fort in Kaskaskia (on the Mississippi River, in southern Illinois) in June $1773 .^{51}$ Despite warnings from local British officials of the strictures against private purchases from the Indians, Murray promptly began negotiations with the Illinois tribes.

Murray dealt with the shells that remained of the once great Illinois tribes. Their population had fallen from around 10,500 in 1680 to 2500 in 1736 and to 500 in 1800 , as they fell victim to European diseases and Indian enemies on all sides. ${ }^{52}$ Unable to prevent neighboring tribes from encroaching on their extensive land, on July 5, 1773, the Kaskaskia, Peoria, and Cahokia tribes ${ }^{53}$ deeded two large

sor] reasoned, actual possession ... would constitute a strength not otherwise attainable." OTIS K. RICE, FRONTIER KENTUCKY 73 (1993).

${ }^{50}$ See Anna Edith Marks, William Murray, Trader $\mathcal{E}^{2}$ Land Speculator in the Illinois Country, in 26 TRANSACTIONS OF THE IIIINOIS STATE HISTORICAL SOCIETY 188, 190-91 (1919) (describing Murray's interaction with the merchants).

${ }^{51}$ Although the fort survives and is part of an Illinois state park, the Mississippi River finally inundated the adjacent town of Kaskaskia in 1899. SeeJohn W. Weymouth \&. William I. Woods, Combined Magnetic $\mathcal{E}^{2}$ Chemical Surveys of Forts Kaskaskia $\mathcal{E}^{\circ}$ de Chartres No. 1, Illinois, 18 HIST. ARCHEOLOGY 20, 29 (1984) (describing how the Mississippi River changed course and destroyed the town of Kaskaskia).

${ }^{52}$ See Emily J. Blasingham, The Depopulation of the Illinois Indians, 3 ETHNOFIST. 361, 372 (1956) (describing settlement patterns and population estimates of Illinois Indians based on historical records). See generally 15 HANDBOOK OF NORTH AMERICAN INDIANS 596-97, 674, 678-79 (William C. Sturtevant ed., 1978) (discussing reasons for the decline of the Illinois Indian population). Blasingham indicates that the Illinois Indian population may have been significantly higher before the $1660 \mathrm{~s}$, when reliable records first became available. See Blasingham, supra, at 361-62. Blasingham attributes this precipitous drop in population to warfare with other Indians, European endemic diseases, the introduction of Christianity and thus monogamy, alcoholism, and the splintering of the tribes. See id. at 373. More recent scholarship, discussed infra Part II.D.I, pinpoints disease as perhaps the most important factor in decimating Indian populations. Smallpox appeared as early as 1701 , and successive epidemics struck again in $1733,1751,1756$, and 1762. See Blasingham, supra, at 383-84.

${ }^{33}$ Less than 100 years earlier, the Illinois Confederation consisted of as many as twelve distinct tribes, but the severe population decline led to a series of mergers and extinctions that left only these three. See 15 HANDBOOK OF NORTH AMERICAN INDIANS, supra note 52 , at 594,673 . 
tracts of land to Murray and the other twenty-one members of the Illinois Company. ${ }^{54}$

Murray and his Philadelphia partners worried about obtaining official recognition for the Illinois Company's deed. Unable to find political support in their own state for their purchase, the Pennsylvanians of the Illinois Company turned to Lord Dunmore, Governor of Virginia. Absent direct royal administration, Virginia claimed, and was recognized to have, jurisdiction over Illinois by virtue of its colonial charter. Murray visited Dunmore in April 1774. An aspiring land speculator himself, the governor apparently agreed to throw his weight behind the Illinois Land Company's claim in return for the opportunity to participate in subsequent transactions. Murray was already talking of a second scheme by May. ${ }^{55}$

To satisfy the desires of the governor, Murray created the Wabash Land Company, of which Lord Dunmore and several men from Maryland, Philadelphia, and London became members....

....

His reward promised, Lord Dunmore wrote to Lord Dartmouth [British Secretary of State] a most cordial recommendation of the Illinois Land Company....

... In a later letter Dunmore denied that he had any connection with the Illinois Land Company, but he kept discreetly silent about the Wabash Land Company.

Instead of negotiating a second purchase himself, Murray recruited a prominent local Frenchman, Louis Viviat, as a partner and an agent. Viviat treated with Piankashaw tribal leaders at Vincennes (Port St. Vincent) and Vermillion, in present-day Indiana. The Piankashaws were one of six tribes classified as Miami Indians. Like the Illinois tribes, the Miami suffered precipitous population declines after contact with Europeans; their numbers fell from 7500 in 1682 to just over 2000 in $1736 .^{57}$

${ }^{54}$ See Map of Land Claims in Johnson v. M'Intosh, supra p. 1067 (showing the land purchased by the Illinois Company). Murray promptly recorded the deed at the Kaskaskia records office. See MEMORIAL OF THE UNITED IIIINOIS AND WABASH LAND COMPANIES TO THE SENATE AND HOUSE OF REPRESENTATIVES OF THE UNITED STATES iii, 11-15 (Baltimore, Robinson 1816) [hereinafter 1816 MEMORIAL] (providing Murray's own account of the events and transactions of 1773).

${ }^{55}$ See Marks, supra note 50, at 202 (describing a May 16th letter by Murray that discussed his new plan).

${ }^{56}$ ALVORD, supra note 25, at 302, 303 n.35.

${ }^{57}$ See 15 HANDBOOK OF NORTH AMERICAN INDIANS, supra note 52, at 596-97, 688. Population figures for the Piankashaw tribe alone are apparently unavailable. 
Viviat reached terms and executed a deed on behalf of the twenty members of the Wabash Company, ${ }^{58}$ with the Piankashaw representatives on October $18,1775 .^{59}$ This deed also conveyed two large tracts, both along the Wabash River. The first (northern) tract straddled the Wabash between the Cat River and Point Coupee. The second (southern) tract ran from the Ohio River up to the White River. ${ }^{60}$

Viviat apparently did not make efforts to include all the tribes with colorable claims to the lands purchased. In particular, the Weas may have had claims in the southern tract. ${ }^{61}$ In addition, there is evidence that the Piankashaw negotiators did not have the support of their own tribe in making the grant. ${ }^{62}$ These facts are at odds with the case stated in M'Intosh, which represented both purchases as being made from united, consenting tribes with exclusive Indian title. ${ }^{63}$

In order to cure any defects in their title, the Illinois and Wabash Companies did what so many other land speculators did in the early republic: they lobbied the legislature. Lobbying in the early republic was no prettier than lobbying today. In the Continental Congress, land claims formed "the most complicated and embarrassing Subject .... Infinite pains are taken by a certain sett of men vulgarly called Land robbers [jobbers], or Land-Sharks to have it in their power to engross the best lands. ${ }^{64}$

In the early years of the American Revolution, the Companies took two important steps to obtain legislative confirmation of their titles. First, they attracted influential, well-connected investors to bolster their lobbying efforts. James Wilson, who later became one of the primary architects of the Constitution and a Supreme Court Justice,

${ }^{5 s}$ Wabash Company investors included Virginia Governor Lord Dunsmore and Maryland Governor Thomas Johnson-predecessor in interest to the M'Inlosh plaintiffs, Joshua Johnson (his son) and Thomas Graham (his grandson). See Johnson v. M'Intosh, 21 U.S. (8 Wheat.) 543, 555, 561 (1823).

${ }_{59}$ See 1816 MEMORIAL, supra note 54, at 16-24 (providing a copy of the deed).

${ }^{60}$ See Map of Land Claims in Jolnnson v. M'Intosh, supra p. 1067.

61 See 1816 MEMORIAL, supra note 54, at 23-24 (mentioning only Piankashaw chiefs as signatories to the deed).

${ }^{2}$ See RICHARD WHITE, THE MIDDIE GROUND: INDIANS, EMPIRES, AND REPUBLICS IN THE GREAT LAKES REGION, 1650-1815, at 372 (1991) ("Their dalliance with Clark arose at least partially from their need of support for a land sale they had earlier made to the Wabash Company without the consent of the other Piankashaws or of the Weas.").

${ }^{63}$ This illustrates the dangers of relying on facts, especially stipulated facts, in cases that appear to be feigned or collusive. See infra Part I.C.1, which argues that the parties wanted the case to be heard in the Supreme Court despite the lack of any controversy over their separate claims.

64 PaUl WaLlace Gates, History OF PUBLic LANd LAW DEVElopment 64 (1968) (quoting statement of Rep. David Howell of R.I.) (citation omitted). 
was the central figure in the United Company's efforts by $1779 .^{65}$ Other prominent investors were Robert Morris, financier of the American Revolution, ${ }^{66}$ and Dr. Thomas Walker, Thomas Jefferson's guardian and "a dominant figure among Virginia's land speculators in the later 1700s." ${ }^{\text {"S7 }}$ Second, the members of the Illinois Company and the Wabash Company merged on March 13, 1779 in order to pool their resources. ${ }^{68}$ Wilson became chairman of the newly founded company on August 20, 1779.

The shareholders made tentative plans for their first settlements in Illinois. ${ }^{69}$ They proposed to establish their first town at the confluence of the Wabash and Ohio rivers, in the second (southern) tract of the Wabash Company's deed. The rather detailed plans included, inter alia, the widths of streets and alleys (seventy feet and fifteen feet, respectively); taxation based on acreage and improvements; large chunks of free land and subsidies for the first five hundred settlers; and the allocation of surveying costs between the Companies and the settlers. The Companies reserved many town lots for themselves, presumably with the hope that values would appreciate rapidly, thus permitting quick resale at a higher price. ${ }^{70}$

Murray had begun lobbying even before the Companies united. While the British government had clearly rejected the land claims, the happenstance of the American Revolution created a new opportunity for vindicating the titles through the (newly sovereign) State of Virginia, whose colonial charter encompassed Illinois and the rest of the Old Northwest-basically those lands north of the Ohio River and east of the Mississippi. Thus, Murray presented a memorial outlining the

${ }^{65}$ Wilson was an inveterate land speculator, investing in at least two other large schemes: the (in)famous Yazoo lands and the Indiana Company. See GEORGE E. LEWIS, THE INDIANA COMPANY, 1763-1798, at 253 (1941) (describing Wilson as a "great speculator"); C. PETER MAGRATH, YaZOO: LAW AND POLITICS IN THE NEW REPUBLIC 5 (1966) (noting that James Wilson was one of the prominent bankers of the Yazoo companies); M. SAKOISK, THE GREAT AMERICAN LAND BUBBLE 135 (1932) (noting that James Wilson was a "large subscriber" to theYazoo deal).

${ }^{66}$ Morris bought a share of the United Company for 8000 pounds on October 2 , 1779. See Minutes of the United Illinois \& Wabash Land Companies 46 (1778-1782) (on reserve in the collection of the Historical Soc'y of Pa., Phila., call no. HSPL (PH:) Am. 4096) [hereinafter Minutes of the United Companies].

${ }^{67}$ THOMAS PERKTNS ABERNETHY, WESTERN LANDS AND THE AMERICAN REVOLUTION 60 (1937).

${ }^{63}$ See Minutes of the United Companies, supra note 66, at 19 (resolving that the Companies unite).

${ }_{69}$ See id. at 23-25 (proposing the location where the town might be laid out).

${ }^{70}$ For this plan to make financial sense, members must have believed that property values would increase at a faster rate than other investments of comparable risk. 
Companies' land claims to the Virginia legislature in December 1778.

Virginia, however, refused to recognize the Companies' Indian deeds. Indeed, the activities of the Illinois and Wabash Companies led Virginia's legislature, in May 1779, to restate the ancient rule against direct purchases from the Indians. ${ }^{72}$ Virginia's reasoning could not have come as a surprise. "It was stated that no person had ever had the right to purchase lands within the limits of Virginia from the natives, except those persons authorized to make such purchases for the use and benefit of the colony and later the state."73

The fluid political situation, however, soon gave the United Companies a new body to lobby: the American Continental Congress and its successors. Between 1781 and 1796, Wilson drafted no fewer than five memorials to the national legislature pleading the United Companies' case. ${ }^{74}$ Their most frequent refrain was to offer large portions of the Companies' tracts (varying from one quarter to three quarters) to the United States in exchange for recognition of the Companies' title in the remainder. In trying to sell Congress on such a compromise, the United Companies repeatedly emphasized that, by relying on their deeds, the nation could avoid paying the Illinois and Piankashaw Indians anything for lands already sold. "[A] transfer of [the Company's title] to the United States may be rendered effectual, to preclude the necessity of a second purchase, and to bar all future claims of the Indians to the lands in question." ${ }^{75}$ Just in case Congress missed the point, the Companies later reiterated it, with more emotion:

"See Memorial of William Murray (Dec. 26, 1778), in 1 CALENDAR OF VIRGINIA STATE PAPERS AND OTHER MANUSCRIPTS, 1652-1781, at 314 (Wm. P. Palmer ed., Richmond 1875) ("Since ... the Public affairs of America have prevented the Company from settling and improving the said Lands ... the said Company think it necessary ... to notify the Governor, Council \& Legislature of that State, of their Purchase ....").

${ }_{72}$ See AlvORD, supra note 25 , at 341 (noting that "it was declared that the right of preemption of all land within the limits of Virginia belonged to the commonwealth alone") (citing STATUTES AT LARGE OF VIRGINIA, supra note 46, at 97).

${ }^{73}$ LEwS, supra note 65 , at 220 . Virginia's 1779 statute barring private land purchases from the Indians replaced a similar provision that appears to have lapsed prior to the United Companies' purchases. For the legal implications of this lapsed statute in the M'Intosil case, see infra Part I.C.2.

${ }^{74}$ See Minutes of the United Companies, supra note 66, at 82-84 (1781), 98-104 (1782), 105 (1790). The Company granted him an extra share for the first of these memorials; no payment is recorded for the later ones.

75 MEMORIAL OF THE ILIINOIS AND OUBASH LAND COMPANIES 29 (Phila. 1796) [hereinafter 1796 MEMORIAI]; see also MEMORIAL OF IFE ILIINOIS AND WABASH LAND COMPANY 5 (Phila. 1797) [hereinafter 1797 MEMORIAI] (pushing the idea that the United States could gain title to valuable land without paying any additional money). 
[W]e are persuaded that the government of the United States, would not reject a valid title, to the great injury of many of their good citizens; and, at a greater price, recur to the Indians for a new purchase, sinking in their pockets (viz. the Indians) the large sums that have been paid and expended by the first bona fide purchasers, who remain true and faithful citizens of the United States.

Congress never found compromise attractive. From the very first memorial in 1781, Congress rejected the Companies' claims based on the ancient, omnipresent rules against private purchases of land from the Indians: "the said purchase had been made, without the license of the then government, or other public authority, contrary to the common and known usage, in such case established. " did win over a House committee in 1788 , which reasoned that the nation could step into the Companies' shoes, noting, "[h] owever improper it may be in general to countenance private purchases from the Indians ... the United States will be ultimately benefited by an exemption from the expense of purchasing the same Lands."

Winning over a single House committee was as close as the United Illinois and Wabash Companies would ever get to success. A Senate committee found that the value of strictly enforcing the rule against private purchases of Indian lands outweighed the benefits of waiving the rule in this particular case. The Senate Committee rejected the Companies' petition on the predictable grounds that "deeds obtained by private persons from the Indians, without any antecedent authority or subsequent confirmation from the government, could not vest in the grantees ... a title to the lands. ${ }^{79}$

The Companies submitted memorials to Congress in 1802 and 1803 containing little, if any, new material; Congress again summarily refused to recognize the claims. ${ }^{80}$ In 1804 , the Companies also took a stab at administrative relief in the territories by petitioning the commissioners adjudicating the morass of land claims at Vincennes.

${ }^{76}$ ACCOUNT OF PROCEEDINGS, supra note 25, at 69; see also 1797 MEMORIAL, supra note 75 , at $5-6$.

${ }^{77}$ Id. at 57.

${ }^{78}$ Report of Committee: The United Land Companies of the Illinois and Wabash (June 27, 1788), reprinted in 1 TERRITORIAL PAPERS, supra note 31, at 115-16 (1934).

${ }^{79}$ ACCOUNT OF PROCEEDINGS, supra note 25, at 52.

${ }^{80}$ See MEMORIAL OF THE IIINNOIS AND OUABACHE LAND COMPANIES, TO THE HONOURABLE CONGRESS OF THE UNITED STATES (n.p. 1802) [hereinafter 1802 MEMORIAI] (providing the text of the United Companies' petition).

${ }^{81}$ See, e.g., MEMORIAL OF THE ILIINOIS AND WABASH LAND COMPANIES TO THE HOUSE OF REPRESENTATIVES (1810) [hereinafter 1810 MEMORIAL], reprinted in AMERICAN STATE PAPERS: DOCUMENTS, LEGISLATIVE AND EXECUTIVE, OF THE 
Clear directions from Washington, however, barred recognition of the Companies' deeds for the same old reason: the United States would never validate treaties made between the Indians and private persons. ${ }^{82}$ In 1805 , the Secretary of the Treasury summed up the consensus view of the Companies' claims: "[the Companies] have not the shadow of a title to support their claim ... I speak with perfect confidence on that point, because I have read all the Memorials of the Companies and never heard of a more frivolous claim. ${ }^{83}$ Two years later the Secretary made it clear that the United States would have "no hesitation" removing claimants under the Companies' deeds. ${ }^{84}$

The Companies were dormant until 1810, when they submitted a fresh memorial to Congress. Congress rejected the Memorial of 1810 on the same grounds that the British had rejected the Companies' claims before the Revolution. The Companies' attempt to purchase land directly from the Indians contradicted the then-governing Proclamation of 1763 , and the universal rule introduced "at a pretty early day ... regulating the intercourse with Indian tribes, which requires the concomitant assent or subsequent sanction of the Government to a conveyance of lands by Indians, in order to render it valid. ${ }^{195}$ Questioning whether the earlier purchases allowed the United States to buy the same Indian land more cheaply, the Committee found that even so, "to recognize such unauthorized proceedings of individuals with the Indians ... would encroach upon the great system of policy so wisely introduced to regulate intercourse with the Indian tribes. ${ }^{906}$ The Companies resubmitted the 1810 Memorial with trivial additions in 1816, but Congress never even bothered to respond. ${ }^{87}$ The Com-

CONGRess OF THE UNITED States, 2 PUBLIC LANDS 108, 109 (D.C., Gales \& Seaton, 1834) [hereinafter AMERICAN STATE PAPERS] (indicating that the purpose of the petition was to investigate land claims in Vincennes).

${ }^{82}$ See 7 TERRITORIAL PAPERS, supra note 31, at 205-08, 311-12 (1939) (providing letters that indicate the lack of importance associated with private transactions). See generally 1 MESSAGES AND LETTERS OF WILIIAM HENRY HARRISON 102 (Logan Esarey ed., 1922) (indicating the power of the government in approving land grants).

${ }_{83}$ Letter from the Secretary of the Treasury to John Badollet, Register of Deeds at Vincennes (Oct. 23, 1805), reprinted in 7 TERRTORIAL PAPERS, supra note 31, at 312 (1939).

${ }^{84}$ Letter from the Secretary of the Treasury to Michael Jones, Register of Deeds at Kaskaskia (Mar. 28, 1807), reprinted in 7 TERRITORIAL PAPERS, supra note 31, at 445 (1939) (noting that "there will be no hesitation in removing persons" whose claims arise "under the Wabash and Illinois Companies").

${ }^{85}$ Report of the Commiltee on Public Lands (Jan. 10, 1811), reprinted in AMERICAN STATE PAPERS, supra note 81, 2 PUBLIC LANDS 253, 253. Congress cited the long list of the colonial statutes against private land purchases discussed in Part I.A.

\footnotetext{
${ }^{86}$ Report of the Commiltee on Public Lands, supra note 85, at 253.

${ }^{87}$ See 1816 MEMORIAL, supra note 54.
} 
panies' next stop would be federal court.

Meanwhile, the United States was busily buying up Indian lands closer and closer to the United Companies' claims. In 1803, William Henry Harrison obtained all the lands described in the Illinois Company's deed, and more, in a huge 8.9 million acre cession from the Illinois tribes. ${ }^{88}$ The cession specifically notes the tribes were "reduced to a very small number... unable to occupy the extensive tract of country which of right belongs to them. ${ }^{, 89}$ Neighboring Indians disputed the title of such a "decimated and impotent tribe" to so vast a territory, and "there was considerable doubt as to their rightful claim to all the land they had ceded." ${ }^{, 90}$ A recent account labeled the 1803 treaty with the Illinois tribes as "[ $t]$ he most notorious" of Harrison's

${ }^{83}$ See Act of Aug. 13, 1803, 7 Stat. 78, 78-79 (describing the terms of the treaty); PAYSON JACKSON TREAT, THE NATIONAL LAND SYSTEM, 1785-1820, at 404 (1910) (giving acreage of the tract). For maps of this and the other cessions cited, see BUREAU OF AMERICAN ETHNOLOGY, EIGHTEENTH ANNUAL REPORT, at PL CXXIV-XCCVI (1900), reprinled in INDIAN LAND CESSIONS IN THE UNITED STATES (Charles C. Royce ed., 1971). According to the Eighteenth Annual Report, only the Kaskaskia tribe signed this treaty. See id. at 664. However, the official version published in Statutes at Large indicates that, while the Illinois tribes had consolidated under the name Kaskaskia, leaders of all the other Illinois tribes except the Peorias signed the treaty. See Act of Aug. 13, 1803, 7 Stat. 78, 79 (listing as signatories "Ocksinga a Mitchigamian" of the Sioux and "Kee-tinsa a Cahokian" of the Iriquois). The United States obtained a cession from the Peoria and a reaffirmation of the earlier cession from the other Illinois tribes in September 1818. See Act of Sept. 25, 1818, 7 Stat. 181, 182 (providing that to effectuate the cession by the Peoria and to reaffirm the cessions by the other tribes, the Peoria, Kaskaskia, Mitchigamia, Cahokia, and Tamarois "do hereby relinquish, cede, and confirm, to the United States, all the land included within the following boundaries"). The Kickapoo tribe also had colorable claim to some of the lands ceded by the Illinois tribes, and hence the United States purchased their interest in July 1819. See Act of July 30, 1819, 7 Stat. 200, 200 (noting that the Kickapoo Tribe ceded "[a]ll their land the southeast side of the Wabash River").

In their 1810 Memorial to Congress, the United Companies correctly cited this treaty, along with other major cessions overlapping the Wabash Company deeds discussed infra, as intersecting with their claims. See 1810 MEMORIAL, supra note 81, at 109. Felix Cohen asserted that the Treaty of Greenville, 7 Stat. 49 (1795), as amended, Act of June 7, 1803, 7 Stat. 74, ceded the lands at issue in M'Intosh, but this appears doubtful. The primary lands involved in that treaty were far to the east, and while it did include a relatively small tract around Vincennes, Indiana, this tract appears to lie between the two tracts described in the Wabash Company's deed. See Cohen, supra note 5, at 47 n.43. Compare BUREAU OF AMERICAN ETHNOLOGY, supra, at CCXXVI, with Map of Land Claims in Jolinson v. M'Intosh, supra p. 1067.

${ }_{89}$ Act of Aug. 13, 1803, 7 Stat. 78, 78 (Article I of treaty).

90 Reginald Horsman, EXPANSION AND AMERIGAN INDIAN POLICY, 1783-1812, at 146 (1992); see also TREAT, supra note 88, at 169 (discussing the fact that "a considerable cession had been secured from the Kaskaskias in 1803-but other tribes disputed the regions"). 
dealings with tribes that had only tenuous claims to lands ceded. ${ }^{91}$ Harrison dealt with "the remnants of the Kaskaskias under Ducoigne, a band that numbered, according to the United States, only 30 men, women, and children in 1796 but that ceded [all of] southern Illinois [and much of central Illinois] to the United States."

In part because he had to deal with so many disjointed tribes, Harrison acquired the lands described in the Wabash Company's deed through a series of cessions. The United States apparently accepted the weakness of the Piankashaw's claim to all the lands sold to the Wabash Company. In the fall of 1809 , the United States acquired 2.8 million acres that included the first (northern) parcel in the Companies' deed from five other tribes, without paying the Piankashaws a cent. ${ }^{93}$ The Piankashaws were among the tribes ceding lands included in the Wabash Company's second (southern) parcel. ${ }^{94}$ The United States began surveying these lands, a necessary prerequisite to

${ }^{91}$ WHITE, supra note 62 , at 474 n.6.

${ }^{92}$ Id.

${ }^{99}$ Harrison initially signed a treaty with the Miamis (including Eel Rivers), Delawares, and Pottawatamies on September 30, 1809. See Act of Sept. 30, 1809, 7 Stat. 113, 113 (noting the formation of a treaty "between the United States of America, and the tribes of Indians called the Delawares, Putawatimies, Miamies and Eel River Miamies"). This treaty required the United States to obtain the approval of the Weas and the Kickapoos. See id. at 114-15 (noting that the treaty will have no effect unless the tribes agree to it). Harrison obtained these tribes' approvals by the end of the year. See Act of Dec. 9, 1809, 7 Stat. 117, 117 (noting that the Kickapoos agreed to the ninth article of the treaty of September 30, 1809); Act of Oct. 26, 1809, 7 Stat. 116, 116 (noting the Weas' consent to the treaty of September 30, 1809).

${ }_{94}$ The Delaware tribe was the first to sell its rights to lands included in the second (southern) Wabash Company tract, on August 18, 1804. See Act of Aug. 18, 1804, 7 Stat. 81, 81-82. This tract consisted of 1.9 million acres. See TREAT, supra note 88 , at 404. Articles four and five of the treaty denied that the Piankashaws or the Miamis had any right to the lands ceded. See Act of Aug. 18, 1804, 7 Stat. 81, 82 (noting that the Delawares had "exhibited to the above-named commissioner of the United States sufficient proof of their right to all the country which lies between the Ohio and White river"). The United States nonetheless subsequently purchased whatever interests these tribes might have had. See Act of Aug. 21, 1805, 7 Stat. 91, 91 (noting that the Miamis "cede and relinquish to the United States forever, all that tract of country which lies to the south of a line to be drawn from the north east corner of the tract ceded by the treaty of Fort Wayne"); Act of Aug. 27, 1804, 7 Stat. 83, 83 ("The Piankeshaw tribe relinquishes, and cedes to the United States for ever, all that tract of country which lies between the Ohio and Wabash rivers"). The Piankashaws, alone, ceded the portion of the second (southern) Wabash Company west of the Wabash River on December 30, 1805. See Act of Dec. 30, 1805, 7 Stat. 100, 100-01 (noting the terms of the treaty between the United States and the Piankashaw tribe). This tract consisted of 2.1 million acres. See TREAT, supra note 88, at 404 (listing the acres of numerous Indian land cessions). Harrison negotiated both treaties. 
sale, almost immediately after finalizing the treaties. ${ }^{95}$ Land offices were opened in Vincennes, Indiana and Kaskaskia, Illinois in $1804 .^{96}$

\section{The Litigation of Johnson v. M'Intosh}

\section{Prelude}

In their first decade, officials at the Kaskaskia office devoted themselves almost exclusively to sorting out the tangle of preexisting French, British, and early American claims over southern Illinois lands. ${ }^{97}$ New business picked up when surveyors finished their work in the district and Congress passed a "pre-emption" act giving occupiers and improvers (squatters) the right to purchase their claims at the statutory minimum price of two dollars an acre. ${ }^{98}$ Like most preemption acts, Congress limited individual claims to a single quarter section (160 acres)..$^{99}$ Preemptioners purchased about 110,000 acres from $1814-1815 .^{100}$ President Madison finally proclaimed open-market land sales by auction on May 16,1816 , and business boomed. ${ }^{101}$

${ }^{95}$ See Joseph W. Ernst, With Compass and Chain: Federal Land Surveyors in the Old Northwest, 1785-1816, at 251 (1958) (unpublished Ph.D. dissertation, Columbia University) (detailing a map of the Federal Surveys in Illinois, 1804-1815).

${ }_{96}$ See MALCOLM J. ROHRBOUGH, THE LAND OFFICE BusINESS 28-29 (1968) (providing a map of land districts and offices).

${ }_{97}$ See Act of Feb. 12, 1812, 2 Stat. 677, 677-78 (reexamining existing claims and permitting new claims in Kaskaskia district); Act of May 1, 1810, 2 Stat. 607, 607 (confirming claims approved by Kaskaskia commissioners made through 1809); Act of Mar. 3, 1807, 2 Stat. 446, 446-47 (confirming claims to land in Vincennes district); see also SOLON J. BUCR, ILIINOIS IN 1818, at 53 (1917) (discussing the fact that the land office had to deal with preexisting claims).

${ }_{98}$ Act of Feb. 5, 1813, 2 Stat. 797, 797. “[E]very such person ... shall be entitled to a preference in becoming the purchaser from the United States of such tract of land at private sale, at the same price ...." Id. Congress twice extended the time period for preemptive claims in the Kaskaskia district. See Act of Apr. 27, 1816, 3 Stat. 307, 307 (noting a "further provision for settling claims to land in the territory of Illinois"); Act of Feb. 27, 1815, 3 Stat. 218, 218 (extending Illinois land claims "upon the river Mississippi").

See Act of Feb. 5, 1813, 2 Stat. 797, 797 (noting that "no more than one quarter section of land shall be sold to any one individual").

${ }^{100}$ This number is based on receipts for land sales in $1814(\$ 53,000)$ and 1815 $(\$ 207,000)$, combined with the fact that all preemptioners, by statute, paid two dollars an acre. See Arthur H. Cole, Cyclical and Sectional Variations in the Sale of Public Lands, 1816-1860, in THE PUBLIC LANDS: STUDIES IN THE HISTORY OF THE PUBLIC DOMAIN 229, 234 (Vernon Carstensen ed., 1968) (providing a table of the receipts from public land sales).

${ }^{101}$ See 1 CIS Index to Pres. Exec. Orders \& Proc. 98 (1986) (announcing the executive order for a public land sale at Kaskaskia). Receipts went from $\$ 207,000$ in 1816 , to $\$ 572,000$ in 1817 , and to $\$ 1,491,000$ in 1818. See Cole, supra note 100 , at 234. 
This legal chronology raises questions about the purchases by the defendant, William McIntosh, in Johnson v. M'Intosh. ${ }^{102}$ He obtained the lands at issue in the case (fifty-three tracts amounting to nearly 12,000 acres) on April 24, $1815,{ }^{103}$ before the first public sale. The law limited preemption claims to 160 acres, and it is extremely doubtful that McIntosh had claims dating from British or French rule to over 11,000 acres scattered all over southern Illinois. How, then, did McIntosh manage to get patents from the federal government to all this land, at the statutory minimum price, before the government auctioned it to the public?

There are two possibilities, both consistent with what little is known of McIntosh. First, he may have engaged in a massive fraud, claiming preemptive or colonial rights to acreage 100 times the per person limit. More likely, and consonant with a large body of evidence, is that McIntosh obtained these lands from preemptioners and colonial claimants in return for the legal services he rendered to help establish their claims. McIntosh served as the voice of French claimants in southern Indiana and Illinois as early as $1803,{ }^{104}$ and William

${ }^{102}$ William McIntosh served as treasurer of the Indiana Territory circa 1804, and like many other frontier officials, "jumped in at the very beginning of [his] residence in the new territories to acquire [land] claims." GATES, supra note 64, at 92; see also Letter from Michael Jones, Register of Land Office at Kaskaskia, to Albert Gallatin, Secretary of the Treasury (May 18, 1804), reprinted in 7 TERRITORIAL PAPERS, supra note 31, at 194 (1939) (noting that William McIntosh owned "vast quantities of real property").

See District Court Records of Johnson v. M'Intosh, microformed on National Archives Microfilm Publications (Supreme Court Case Files), Film M-214 (1792-1831), Roll 56, Frame 410 [hereinafter District Court Records of M'Intosh] (describing McIntosh's acquisitions). The district court records of McIntosh's purchases match exactly the patents issued to him as recorded in a database of all the United States patents issued for land in Illinois. See State of Illinois Public Domain Land Tract Sales Archive (last modified Jan. 18, 2000) <http://www.sos.state.il.us/depts/archives/data_lan.html> (containing transaction data for public domain land sales in Illinois). The Supreme Court dates the purchases three years later, in 1818, when the federal government issued patents. See Johnson v. M'Intosh, 21 U.S. (8 Wheat.) 543, 560 (1823). Such delays between purchase and issuance of patent were common. See ROHRBOUGH, supra note 96, at 175 (noting that "the delay in the issue of patents had become severe enough to necessitate a circular to the land offices on the reasons for the delay"). The Supreme Court's acreage count, 11,560 acres, based on the parties' stipulated facts, appears to be off; the land records indicate McIntosh purchased 11,982.81 acres (44 quarter sections, one half section, six sections, a fractional section (521.21 acres) and a fractional half section (260.6 acres)). According to the Illinois Public Domain Land Tract Sales Archive database, McIntosh paid the statutory minimum of two dollars per acre for all these parcels. See State of Illinois Public Domain Land Tract Sales Archive, supra.

${ }^{104}$ See Letter from William McIntosh to the President [Jefferson] (Dec. 15, 1807), reprinted in 7 TERRITORIAL PAPERS, supra note 31, at 503 (1939) (addressing Jefferson "on behalf of the french Inhabitants of Vincennes"); Letter from William McIntosh to 
Henry Harrison, Governor of the territories, identified McIntosh as one of "the principal councellors of the Kaskaskias Speculators."

The historical record of the plaintiffs in M'Intosh is thinner and much less colorful. Thomas Johnson, an original investor in the Wabash Company, and later a Supreme Court Justice, died on or about November 1, 1819, and the plaintiffs, his son Joshua and grandson Thomas Graham, were the primary beneficiaries in his will. Perhaps more importantly for the commencement of the M'Intosh litigation, the will made Robert Goodloe Harper executor of the estate. ${ }^{106}$ Harper apparently determined that Johnson owned shares and decided to go to court in a final stab at giving a happy ending to the long and sad story of the United Illinois and Wabash Land Companies.

Looking for a federal patent holder to sue, as a test of the validity of their claim under the Wabash Company's Indian deed, Johnson and Graham, probably led by Harper, appeared to target McIntosh. As one of the largest landholders in the Illinois and Indiana territories, McIntosh was a natural adversary, but he does not appear to have been a real one. Mapping the United Companies' claims alongside McIntosh's purchases, as enumerated in the district court records, shows that the litigants' land claims did not overlap. ${ }^{107}$ Hence there was no real "case or controversy," and M'Intosh, like another leading early Supreme Court land case, Fletcher $v$. Peck, appears to have been a sham. $^{108}$

the President [Jefferson] (Mar. 30, 1808), reprinted in 7 TERRITORIAL PAPERS, supra note 31, at 537 (1939); Memorial to Congress by Inhabitants of Knox County (Nov. 8, 1808), reprinted in 7 TERRIORIAL PAPERS, supra note 31, 612-13 (1939) (including a signature for Israel Rowland "by [William] McIntosh his agent"); Petition to Congress by Inhabitants of Knox, St. Clair, and Randolph Counties (Oct. 22, 1803), reprinted in 7 TERRTORIAL PAPERS, supra note 31, at 125, 128 (1939) (including William McIntosh among the petitioners).

${ }^{105}$ Letter from Governor Harrison to the Secretary of the Treasury Albert Gallatin (Aug. 29, 1809), reprinted in 7 TERRrTORIAL PAPERS, supra note 31, at 669 (1939).

${ }^{106}$ See Letter from Roger Taney to Robert Goodloe Harper (Dec. 4, 1819), in Harper Papers, Legal Correspondence, 1797-1824 (on reserve in the Maryland Hist. Soc'y Collection, Baltimore, Md., MS 1884, acc. no. 55,644) (describing the details of the execution of Mr. Johnson's will).

${ }^{107}$ See Map of Land Claims in Johnson v. M'Intosh supra p. 1067. For a detailed description of the sources used to derive this map, see Kades, supra note 19 app.

${ }^{108}$ See MAGRATH, supra note 65 , at 54-55 (showing that Fletcher v. Peck, 10 U.S. (6 Cranch) 87 (1810), resolving the Yazoo land case, was feigned); see also 1 CHARLES WARREN, THE SUPREME COURT IN UNITED STATES HISTORY 147 (1926) (arguing that Hylton v. United States, 3 U.S. (3 Dall.) 171 (1796), was feigned). The Supreme Court has repeatedly ruled that federal courts have no jurisdiction in feigned cases since there is no "case or controversy." See, e.g., Moore v. Charlotte-Mecklenburg Bd. of Educ., 402 U.S. 47, 48 (1971) (dismissing for lack of jurisdiction because of the absence of a "case or controversy"); Lord v. Veazie, 49 U.S. (8 How.) 250, 255 (1850) 
McIntosh did not contest a single fact alleged in the complaint, jurisdictional or otherwise. Perhaps he participated in framing the complaint, which became the stipulated facts of the case. Neither the district court nor the Supreme Court questioned any of these facts. ${ }^{109}$ Everyone involved, it seems, wanted a decision on the legal question of the validity of private purchases from the Indians.

The plaintiffs' case thus commenced in the United States District Court for Illinois in December $1820,{ }^{110}$ in Vandalia, Illinois. The parties apparently agreed to a bench trial, and the judge gave them leave "to make a stated and agreed case of facts for the consideration of the Court."111 Without providing any substantive opinion, the court rendered judgment for the defendant. ${ }^{112}$ As yet another piece of evidence that both sides wanted a final answer to the question presented in the case, McIntosh waived his right to force the plaintiffs to post an appeal bond. ${ }^{113}$

The plaintiffs filed a writ of error "by consent" in the Supreme Court on February 5, 1822, one more indication that McIntosh wanted the case heard at the highest level despite his victory in district court. $^{114}$ Unsurprisingly, Robert Goodloe Harper, along with Daniel Webster, served as counsel for the plaintiffs. Argument spanned four days, and only nine days later the Court affirmed the district court's judgment for the defendant. ${ }^{115}$

\section{Supreme Court Arguments and Holding}

The bulk of Webster and Harper's reported argument for the plaintiffs focused on narrow statutory issues. They claimed (1) that banning the purchase of lands from a foreign sovereign was a legislative act beyond the power of the Crown acting without consent of Parliament, and thus that the Proclamation of 1763 was void; and (2) that

("[T]here must be an actual controversy, and adverse interests."). This case law, of course, is based on Article III of the Constitution. See U.S. CONST. art. III, $\$ 2$, cl. 1 (limiting judicial power to cases and controversies).

${ }_{109}$ See Johnson v. M'Intosh, 21 U.S. (8 Wheat) 543, 543-71 (1823).

${ }^{110}$ See District Court Records of M'Intosl, supra note 103, Frame 422.

III Id. Frame 347.

${ }^{112}$ See M'Intosh, 21 U.S. (8 Wheat.) at 604.

${ }^{113}$ See District Court Records of M'Intosh, supra note 103, Frames 420-21.

${ }^{114}$ See Supreme Court February Term 1821 (docket sheets), microformed on National Archives Microfilm Publications, Series 216, Roll 1, Frame 408. The Supreme Court received the district court records almost a year before the plaintiff finally filed the writ of error. See id.

${ }^{115}$ The case was argued February 15 and 17-19, 1823; judgment was entered on February 28, 1823. See id. 
colonial Virginia's 1662 statute banning such purchases had lapsed (or been repealed), and that its reenactment in 1779, after the United Companies' purchases, could not divest the Companies of vested rights ex post. ${ }^{116}$

Chief Justice Marshall, in a brief detour toward the end of the Court's unanimous opinion, summarily rejected both contentions. Simply disagreeing with the plaintiffs' first point, he declared that the Crown retained exclusive power to deal with "vacant lands," including Indian lands, as it pleased. ${ }^{117}$ Much more peculiar was Marshall's response to the supposedly lapsed and tardily reenacted Virginia statute banning private purchases. The only evidence that the statute of 1662 had been repealed, it seems, was a "marginal note opposite to the title of the law, forbidding purchases from the Indians, in the revisals of the Virginia statutes, stating that law [the 1662 statute] to be repealed."118 Marshall did not argue that a marginal note beside a title was insufficient evidence that the legislature had repealed the statute; indeed, he explicitly refused to recognize that the 1779 law could "countervail the testimony furnished by the marginal note." stead found that the 1779 law could "safely be considered as an unequivocal affirmance, on the part of Virginia, of the broad principle which had always been maintained, that the exclusive right to purchase from the Indians resided in the government."120

This discussion will return momentarily to what Marshall meant by "broad principle ... always ... maintained." There is a more immediate question: why did Marshall not limit his opinion to these two points? If either the Proclamation of 1763 or the Virginia colonial statute of 1662 (or the "broad principle" behind it) were good law at the time of the United Companies' purchases, then those purchases were clearly illegal. A contemporary New York case rejected an Indian deed precisely on such narrow grounds. ${ }^{121}$ The main difference be-

${ }^{116}$ See supra note 46 (citing, inter alia, a Virginia statute of 1662 barring private purchases of Indian lands).

${ }_{117}$ See Johnson v. M'Intosh, 21 U.S. (8 Wheat.) 543, 595-96 (1823) ("[A]ll vacant lands are vested in the crown, as representing the nation; and the exclusive power to grant them is admitted to reside in the crown, as a branch of the royal prerogative."). Marshall distinguished the plaintiffs' primary supporting case, Campbell v. Hall, 1 Cowp. 204, 98 Eng. Rep. 1045 (1774), as involving royal imposition of a lax. Parliament, not the Crown, had the exclusive power to tax. See M'Intosh, 21 U.S. (8 Wheat.) at 597 .

${ }^{118}$ M'Intosh, 21 U.S. (8 Wheat.) at 585.

${ }^{119} I d$.

${ }^{20}$ Id.

${ }^{121}$ See Goodell v. Jackson, 20 Johns. 693, 722-34 (N.Y. 1823) (refusing to recognize 
tween this approach and the broader rule Marshall enunciated is that a more limited ruling would leave loopholes for future litigation-for example, what if a colony had a lapsed statute and some speculators made purchases before the Proclamation of 1763? Marshall thought the stakes were important enough to warrant a universal rule barring private purchases from the Indians.

Scholars have justly complained about the "tumbling logic" of Marshall's opinion, ${ }^{122}$ and its "conflicting and confusing potpourri of arguments." ${ }^{123}$ Yet there is an underlying structure to the opinion, and the arguments from Marshall's "conflicting and confusing potpourri" can still be distilled and assessed, each in turn. It has already become evident, for example, that the Proclamation of 1763 and the colonial statutes were too narrow to support a more general holding. Most other arguments in Marshall's opinion can be ignored as mere dicta unnecessary to decide the case.

In order to find the true holding, the inquiry must start with the question Marshall proposed to answer. Here, at least, in its very first paragraph, the opinion is crystal clear: "the question is, whether [the United Companies'] title can be recognised in the Courts of the United States?"124 The key clause is the last one, "in the Courts of the United States." Marshall used this phrase in the first paragraph of the opinion and repeated it in the very last paragraph. ${ }^{125}$ It at first seems superfluous; what courts, other than the courts of the United States, could possibly be relevant to the dispute?

The answer is Indian courts. Marshall laid out the two tiers governing rights in American lands: the discovery rule that regulated inter-European claims, and "[t]hose relations which were to exist between the discoverer and the natives. ${ }^{226}$ The Indians' rights to their lands, defined in the second tier, "were, in no instance, entirely disregarded; but were, necessarily, to a considerable extent, impaired."127 The discovery rule itself, Marshall noted, prevented the Indians from selling to other sovereigns. Under colonial practice, however, the In-

an Indian grant based on an exhaustive analysis of the New York Constitution of 1777, article 37, and a long line of colonial and state statutes forbidding land transactions with Indians).

${ }_{122}$ Henderson, supra note 23, at 87.

${ }^{123}$ David E. Wilkins, Johnson v. M'Intosh Revisited: Through the Eyes of Mitchel v. United States, 19 AM. INDIAN L. REV. 159, 166-67 (1994).

${ }^{124}$ M'Intosh, 21 U.S. (8 Wheat) at 572.

${ }^{125}$ See id. at 604-05 ("[P]laintiffs do not exhibit a title which can be sustained in the Courts of the United States ....").

${ }_{126} I d$. at 573.

${ }^{127}$ Id. at 574. 
dians were not stripped of all rights; they retained what Marshall labeled the "Indian title of occupancy," which could be extinguished only "by purchase or by conquest."

The plaintiffs, then, via their predecessor (a member of the Wabash Company and then the United Companies), purchased this Indian title of occupancy. Since they purchased Indian title, Marshall directed them to an Indian forum for a remedy.

[The plaintiffs hold] under [the Indians], by a title dependent on their laws. The grant derives its efficacy from their will; and, if [the Illinois and Piankashaw tribes] choose to resume it, and make a different disposition of their land, the Courts of the United States cannot interpose for the protection of the title. The person who purchases lands from the Indians, within their territory, incorporates himself with them, so far as respects the property purchased; holds their title under their protection, and subject to their laws.

Included in the Indians' title of occupancy was the power to sell lands to the discovering sovereign that a tribe had previously conveyed to someone else. Thus, as Milner Ball puts it, "[ $t]$ he plaintiffs' claim to the land was defeated principally because the Indians themselves had extinguished plaintiffs' interest [by the later sale to the United States]." ${ }^{130}$

Marshall, then, created a rather strange two-tiered land tenure system: Indian title of occupancy applied before American purchase or conquest, and the common law of the several states applied after. The courts of the United States had no jurisdiction over claims based on Indian title of occupancy. The dual land tenure system explains why the plaintiffs lost the case: they purchased the Indian title of occupancy, which the Indians could and did extinguish under the law of the United States, by reselling to the United States.

\section{Marshall's Version of Indian Title}

What is less clear in M'Intosh is the precise contours of the Indian title of occupancy. The most important question for the Indians, given that they could sell full title only to the United States, was whether they could refuse to sell. Marshall's black letter rule, that the

128 Id. at 587.

129 Id. at 593. Marshall knew full well, of course, that there was no Indian court to hear the plaintiffs' grievance. In the very next sentence, he observed, "[i]f they annul the grant, we know of no tribunal which can revise and set aside the proceeding." Id.

${ }^{\text {Bso }}$ Ball, supra note 23, at 26; see also Henderson, supra note 23, at 93-96 (discussing tribal title and tribal tenurial systems, and their treatment in $M$ 'Intosh). 
United States could divest the Indians of title only via purchase or conquest, was consistent with earlier doctrine, discussed in Part I.A. The word "conquest" was subsequently limited to "defensive wars" or those fought for some other "just cause." ${ }^{\text {n191 }}$ In addition to purchase and just conquest, later cases held that the Indians could lose their title of occupancy by abandonment. ${ }^{132}$ Outside of these elaborations, the Supreme Court has never altered the rules established in M'Intosh.

Formally, then, describing Indian title as amounting to "only a tenancy at sufferance" ${ }^{\text {133 }}$ is misleading, since under M'Intosh the Indians could remain on their land and refuse to sell, as long as they remained peaceful. Marshall specifically deemed them "rightful occupants," the antithesis of tenants at sufferance, whom the law distinguishes from trespassers only by the legality of their original $e n$ try. The opinion casts Indians as term-of-year tenants with full rights to renew, rather than as tenants at sufferance subject to immediate eviction. As a matter of realpolitik, however, the sufferance label may have been accurate. ${ }^{134}$

As peculiar as Indian title seems in and of itself, even stranger is its

${ }^{131}$ Worcesterv. Georgia, 31 U.S. (6 Pet) 515, 545 (1832).

192 Abandonment explains Marsl v. Brooks, 55 U.S. (14 How.) 513 (1852), in which the Court ruled that the holder under a federal patent could adversely possess against the Indians, despite the failure of the government to extinguish Indian title. See id. at 521-24. Without appealing to abandonment as the basis for extinguishing title, this case would be inconsistent with M'Intosh, empowering a private citizen to do by occupation what she could not do by purchase. The Court formally declared that abandonment can extinguish Indian title in Williams v. City of Chicago, 242 U.S. 434, 437-38 (1917) ('[W] hen [the Indians' right of occupancy] was abandoned all legal right or interest which both tribe and its members had in the territory came to an end.").

Arguably, Chief Justice Marshall alluded to abandonment in M'Intos/h. After describing Indian migrations caused by settlers thinning the game population, he noted that "[t] he soil, to which the crown originally claimed title, being no longer occupied by its ancient inhabilants, was parceled out according to the will of the sovereign power." M'Intos/, 21 U.S. (8 Wheat.) at 591 (emphasis added). The practical importance of game-thinning in expropriating Indian lands is examined infra Part II.D.2.

${ }^{133}$ Philip P. Frickey, Marshalling Past and Present: Colonialism, Constitutionalism, and Interpretation in Federal Indian Law, 107 HARV. L. REV. 381, 386 (1993).

${ }^{134}$ Later Supreme Court decisions have made Indian title more like tenancy at sufferance. In Tee-Hit-Ton Indians v. United States, 348 U.S. 272, 285 (1955), the Court held that tribes had no Fifth Amendment constitutional right to compensation for a taking of their title of occupancy. Payment is made at the pleasure of the government. This case seems to contradict M'Inlosh, since it permits extinguishment of Indian title without purchase, just conquest, or abandonment. At bottom, however, it merely shows that M'Intosh was not decided on constilutional grounds. It also makes sense within Marshall's system of dual land tenure systems: there are no remedies in "the Couts of the Uniled States" for rights based on Indian tenure, whether held by the plaintiffs in M'Intosiz or the Indians in Tee-Hit-Ton. 
coexistence with European title in Marshall's dual land tenure construct. Real property was still the centerpiece of the common law in 1823, and few common law doctrines were as deeply established as the principle that all titles were rooted in a unique sovereign, be it the Crown, a state, or the federal government. Marshall himself apparently found it most odd that, under this system of dual land tenure, European sovereigns could convey titles before they had extinguished Indian title. He devoted almost half of his opinion ${ }^{135}$ to laying out the historical record that "our whole country [has] been granted by the crown while in the occupation of the Indians." "Wh Why did Marshall devote so much time to summarizing long historical practice? Why did he emphasize that grants of European title before extinguishment of Indian title were "understood by all," "exercised uniformly," and extended "universal recognition" as legitimate? ${ }^{137}$

\section{Legal Basis for the M'Intosh Rule: Custom}

The answer is tied to the basis for the holding in M'Intosh: custom. Phrases like "understood by all," "exercised uniformly," and "universal recognition" appeal to long-established practice, not to any specific constitutional, statutory, or common law rule. "Common practices, sanctioned by general usage, that cover ... similar situations are what... (in accordance with long usage) [is meant] by customs." ${ }^{\text {138 }}$

Basing customary law on a general, long-term statutory usage is admittedly unusual; it ordinarily arises via long private practice, independent of formal rule creation by a public entity. While most customary legal rules may have arisen from entirely unofficial acts, drawing on old statutes for customary law is (perhaps surprisingly) quite

${ }^{135}$ See M'Intosh, 21 U.S. (8 Wheat.) at 574-88 (discussing the history of American land ownership).

136 Id. at 579. One scholar has argued that this extended discussion was no more than tracing the chain of the United States's title, complaining that the "Court spent an extravagant amount of time in establishing the principle that the ultimate title to land within the United States was held by the federal government as the successor-ininterest to the discovery by England." Henderson, supra note 23, at 90. Marshall focused, however, on the fact that various grants were made while the Indians occupied the lands, rather than on the legitimacy of each transfer. He adverts to grants made "notwithstanding the occupancy of the natives," or "while in the occupation of the Indians," no less than nine times in the course of discussing the history of the dual land tenure regime in America. M'Intosh, 21 U.S. (8 Wheat.) at 577-88.

${ }^{137}$ M'Intosh, 21 U.S. (8 Wheat.) at 574, 588.

${ }^{138}$ Richard A. Epstein, The Path to The T.J. Hooper: The Theory and History of Custom in the Law of Tort, 21 J. LEGAL STUD. 1, 6 (1992). 
consistent with the rationale behind English customary law. "The theory of English law was that, if there had been a usage from time immemorial..., it might fairly be presumed that it arose under an act of Parliament or other public act of governing power, the best evidence of which had perished., ${ }^{\text {,39 }}$

This theory-that custom evidenced ancient and lost legislative will—dovetails well with Marshall's blithe response to the possibility that the relevant Virginia colonial statute barring private purchases had lapsed. He considered the later reenactment of a similar provision "as an unequivocal affirmance, on the part of Virginia, of the broad principle which had always been maintained, that the exclusive right to purchase from the Indians resided in the government."140 Marshall seemed to say that the longstanding customary legislative practice of barring private purchases of Indian title was so strong that it overrode the "mere technicality" of a lapsed or repealed statute.

This is a powerful form of customary law, which is usually seen as subordinate to statutory formalities. ${ }^{141}$ Marshall displayed a similarly strong deference to custom in response to the plaintiffs' argument that the enactment of the numerous statutes barring private purchases $^{142}$ showed that the background (common law) rule, absent such statutes, was that such purchases were valid. He enlisted the very existence of these statutes to make the case for a customary rule of law: "[T]he fact that such acts have been generally passed, is strong evidence of the general opinion, that such purchases are opposed by the

${ }^{139}$ Graham v. Walker, 61 A. 98, 99 (Conn. 1905). The Supreme Court had long taken the same view.

[C] ustom ... is always presumed to have been adopted with the consent of those who may be affected by it. In England, and in the states of this Union which have no written constitution, it is the supreme law; always deemed to have had its origin in an act of a state legislature.... The court not only may, but are [sic] bound to notice and respect general customs and usage, as the law of the land, equally with the written law, and when clearly proved, they will control the general law; this necessarily follows from its presumed origin-an act of partiament or a legislative act.

United States v. Arredondo, 31 U.S. (6 Pet) 691, 714 (1832) (emphasis added).

${ }^{140}$ M'Intosh, 21 U.S. (8 Wheat) at 585.

141 Marshall may have borrowed the idea of a customary basis for his opinion from the defendants, who argued that the "uniform understanding and practice of European nations" rendered the plaintiffs' deeds void. Id. at 567. The roots of using custom as a ground for deciding cases may go back to the Continental Congress's reply to the United Companies' first memorial to the federal government, which deemed private purchases against "common and known usage." ACCOUNT OF PROCEEDINGS, supra note 25 , at 57 .

${ }_{142}$ See discussion supra Part I.A (explaining land, title, and alienability in early America). 
soundest principles of wisdom and national policy. ${ }^{143}$ Universal, uniform, and longstanding legislation summed to a customary rule greater than its statutory parts.

That said, Marshall did not even hint that Congress was powerless to reverse his opinion by statute and to permit private citizens to buy land directly from the Indians. That is, there is no evidence that M'Intosh created a constitutional rule. A reading of M'Intosh, as decided on customary grounds, is consistent with the general ability of parties to contract around customary laws. "[C] ustom is best understood as setting out the 'right' default provisions, not as creating a body of mandatory terms."

Also consistent with a customary law reading of $M$ 'Intosh is the fact that Marshall was not troubled that different rules might apply elsewhere in the British Empire. In Britain, custom was usually local (applying only to a manor, village, parish, or similarly small group). On precisely such parochial grounds, Marshall dismissed the relevance of the Camden-Yorke opinion (approving private purchases of land in India) that was relied on so heavily by the original members of the United Companies. Without explaining why America should have a different rule, Marshall merely noted that the opinion referred to "'princes or governments," terms "usually applied to the East Indians, but not to those of North America. We speak of their sachems, their warriors, their chiefmen, their nations or tribes, not of their 'princes or governments." "15 Marshall admitted that the Camden-Yorke opinion stood for the proposition that "the king's subjects carry with them the common law, wherever they may form settlements."146 While the common law generally permitted purchases of foreign lands, Marshall's opinion implies that customary practice in America created an exception to this rule. He argued that the system of dual land tenure "adapted to the actual condition of the two people" was "indispensable to that system under which the country has been settled"-such an essential practice, Marshall said, "cannot be rejected by courts of justice." 147 Not only was the custom of barring private purchases from the Indians immune to legislative lapse, it was wholly beyond the

${ }^{143}$ M'Intosh, 21 U.S. (8 Wheat) at 604.

${ }^{144}$ Richard A. Epstein, International News Service v. Associated Press: Custom and Law as Sources of Property Rights in News, 78 VA. L. REV. 85, 87 n.6 (1992) [hereinafter Epstein, Custom and Law].

${ }_{145}$ M'Intosh, 21 U.S. (8 Wheat.) at 600.

${ }^{146} I d$.

${ }^{147} I d$. at 591-92. 
power of common law courts to alter.

Admittedly, early American courts rarely recognized custom as a basis for law. Until a modern resurgence, "'custom' had almost no authority in American law." 148 In reviewing cases involving rights of public access to roads and waterways, however, Carol Rose found that while courts usually rejected it as the basis for legal rights, custom "provides powerful insights into the nature of "inherently public property." 149 Courts have often declined to invoke custom explicitly in their holdings, even when their reasoning in effect relies on it. In Intermational News Service v. Associated Press, ${ }^{150}$ for instance, the Court discussed customary news industry practices at length to support its recognition of property rights in news. Richard Epstein has argued that "the easiest way to defend the result in [International News Service] is to recognize the force of custom in the creation of the property rights," even if the Court did not explicitly base its holding on industry custom. " "[T] ${ }^{151}$ INS decision and the cases following it reached results consistent with the custom of the news-gathering industry, although they did not purport to derive their rules from custom."

So, too, in M'Intosh, Marshall never invokes the word "custom," yet the passages from the opinion cited above show that custom is a recurrent theme that underlies the holding of the case. Given the long and uninterrupted line of statutes in every colony, it was likely unthinkable to Marshall, the other Justices, and most Americans that private citizens could purchase land directly from the Indians. There ex-

${ }^{148}$ Carol Rose, The Comedy of the Commons: Custom, Commerce, and Inherently Public Properly, 53 U. CHI. L. REv. 711, 717 (1986) (footnote omitted). A number of American courts in the 1800 s did recognize customary practices in the whaling industry. See generally ROBERT C. ELLICKSON, ORDER WITHOUT LAW: HOW NEIGHBORS SETTLE DISPUTES 191-206 (1991) (examining the practices of the New England whaling industry in using custom to create rules establishing property rights). More recently, courts in a number of jurisdictions have accepted custom-based rights of the public to use otherwise private beaches. See, e.g., Stevens v. City of Cannon Beach, 854 P.2d 449, 460 (Or. 1993) (finding no taking of property within the meaning of the Fifth Amendment based, in part, on the "common law of custom"); City of Daytona Beach v. Tona-Rama, Inc., 294 So. $2 d$ 73, 78 (Fla. 1974) ("If the recreational use of the sandy area adjacent to mean high tide has been ancient, reasonable, without interruption and free from dispute, such use, as a matter of custom, should not be interfered with by the owner."); County of Hawaii v. Sotomura, 517 P.2d 57, 61 (Haw. 1973) (arguing that the longstanding public use of beaches "ripened into a customary right" consistent with favoring such use as a matter of public policy).

\footnotetext{
${ }_{149}$ Rose, supra note 148 , at 722.

150248 U.S. 215 (1918).

151 Epstein, Custom and Law, supra note 144, at 106.

152 Id. at 124.
} 
ists abundant evidence that the customary norm behind the M'Intosh rule was deeply recognized in American society.

In a leading antebellum treatise on constitutional law, Chancellor Kent described the basis for Marshall's opinion in words that support a customary reading:

[The M'Intosh rule] is established by numerous compacts, treaties, laws, and ordinances, and founded on immemorial usage. The country has been colonized and settled, and is now held by that title. It is the law of the land, and no court of justice can permit the right to be disturbed by speculative reasonings on abstract rights. ${ }^{155}$

Further support for inferring custom as the basis of Marshall's holding comes by process of elimination: all other possibilities are either explicitly contradicted by, or implicitly dissonant with, Marshall's opinion. The discussion above highlighted Marshall's rejection of both statutory and common law bases for the rule of M'Intosh. $\mathrm{He}$ flatly rejected both natural and international law, ${ }^{154}$ defending the rule against private purchases from Indians " $[h]$ owever this restriction may be opposed to natural right, and to the usages of civilized nations."155 From the discussion of the discovery rule, itself clearly a rule of international law, it was already clear that a different set of rules regulated relations between Europeans and Indians. ${ }^{156}$ He declared that domestic law (of unspecified source) must decide property cases:

As the right of society, to prescribe those rules by which property may be acquired and preserved is not, and cannot be drawn into question; as the title to lands, especially, is and must be, admitted, to depend entirely on the law of the nation in which they lie; it will be necessary, in pursuing this inquiry, to examine, not simply those principles of abstract justice, which the Creator of all things has impressed on the mind of his creature man, and which are admitted to regulate, in a great degree, the rights of civilized nations, whose perfect independence is acknowledged; but those principles also which our own government has adopted in the particular case, and given us as the rule for our decision. ${ }^{157}$

${ }^{153}$ KENT's COMMENTARIES, supra note 46 , at *381 (emphasis added).

${ }^{154}$ Marshall seemed to define international law, in large part, as a subspecies of natural law. He rejected relying entirely on "principles of abstract justice, which the Creator of all things has impressed on the mind of his creature man, and which are admitted to regulate, in a great degree, the rights of civilized nations." M'Intosh, 21 U.S. (8 Wheat.) at 572.

${ }^{155} I d$. at 591 .

${ }^{156}$ See id. at 573 ("Those relations which were to exist between the discoverer and the natives, were to be regulated by themselves.").

ISt. at 572. 
In extensive, apologetic dicta, Marshall offered "excuse, if not justification," 158 for refusing to extend intra-European civility, under the guise of natural or international law, to the Indians. While natural and international law usually required a conqueror to integrate members of the defeated population into its own and extend them equal property rights, Marshall claimed that an agricultural and industrial society simply could not incorporate hunters like the Indians. He refused to justify this less favorable treatment on the theory that "agriculturists, merchants, and manufacturers, have a right, on abstract principles, to expel hunters from the territory they possess, or to contract their limits," deeming irrelevant such "speculative opinions ... respecting the original justice of the [Europeans'] claim."159

The reporter classified the case as "Constitutional Law" without elaboration, and the index heading entitled "Constitutional Law" makes no less than fifteen references to the case. ${ }^{160}$ While it is possible to imagine the M'Intosh plaintiffs invoking the Due Process Clause or the Takings Clause, they do not mention either, and neither does the Court. Marshall also did not cite the Constitution's grant of exclusive jurisdiction over Indian affairs to Congress. In fact, there is not a single reference to the United States Constitution. ${ }^{161}$ Finally, as previously discussed, Marshall never suggested that Congress was powerless to reverse his opinion and to permit private citizens to purchase land directly from the Indians. Thus, it is difficult to argue that M'Intosh is a constitutional case, at least as the term is commonly used. ${ }^{162}$

\section{EFFICIENT EXPROPRIATION}

Part I traced the roots of M'Intosh in colonial land practices and the acts of speculators that contradicted established (customary) practice. It then analyzed how Chief Justice Marshall upheld the longstanding bar against private purchases of land from the Indians. Part

158 Id. at 589.

159 Id. at 588.

${ }^{160} I d$. at 543 , index at $31-32$.

161 There are references to the (unwritten) British Constitution regarding the Crown's power to bar private land purchases in the Proclamation of 1763, but this discussion was irrelevant to the holding. See id. at 594-97 (outlining the scope of authority granted to the King of Great Britain in distributing parcels of land in colonial territories to his subjects).

${ }^{162}$ Philip Frickey argues that M'Intosh was a "quasi-constitutional" decision, meaning that while it did not bar legislation to the contrary, it established a "clear statement rule" requiring Congress to be explicit about any further erosion of Indian rights. Frickey, supra note 133, at 385. 
II explains why colonial law uniformly and universally barred such purchases and why Marshall made this statutory custom the law of the land.

The rule of M'Intosh was part and parcel of a larger process: efficient (cheap) European expropriation of Indian lands. Just as many contract, tort, property, and other legal rules promote efficient behavior, ${ }^{163} M^{\prime}$ Intosh and a broad range of other colonial and early American laws created rewards and penalties that helped Europeans obtain Indian lands as inexpensively as possible. It is important to stress that the process minimized costs for European colonizers, not for the colonizers and Indians together. This is in contrast with most efficient legal rules that, ex ante at least, benefit all participants in a given activity.

European agricultural colonization undoubtedly presented the possibility of enormous gains from trade. First, "a European immigrant required about two acres to provide for himself in the New World, while Indians required up to a thousand times more." ${ }^{164}$

Moreover, Europeans had a wide variety of manufactured goods of great value to Indians in their traditional way of life, including guns, metal tools, cooking utensils, and warmer clothing. Thomas Jefferson drew the obvious conclusion from these basic economic facts: "[The Indians are] very poor, and they want necessaries with which we abound. We want lands with which they abound; and these natural wants seem to offer fair ground of mutual supply." 165

The only question was, which side would garner the lion's share of the gains from this trade? In a system of purely voluntary exchange, without any coercion on either side, the European farmers might be expected to buy off relatively small corners of Indian hunting grounds for relatively large amounts of trade goods. American land would still have been much cheaper for settlers than it was in heavily populated Europe. The land-rich Indians, while preserving their way of life, would have been glad to part with a modicum of their territory for novel and useful manufactures. This would have been the "market" (based on voluntary exchanges and thus arguably fair) division of the gains from trade between land-rich and manufacturing-rich societies.

${ }^{163}$ For efficiency explanations of a broad range of legal rules, see generally RICHARD A. POSNER, ECONOMIC ANALYSIS OF LAW (5th ed. 1998).

${ }^{164}$ Anderson \& McChesney, supra note 16, at 43 (citing STANLEY LEBERGOTT, THE AMERICANS: AN ECONOMIC RECORD 15-16 (1984)).

16517 THE WRITINGS OF THOMAS JEFFERSON 374-75 (Albert Ellery Bergh ed., 1907) [hereinafter WRITINGS OF JEFFERSON]. 
This, of course, is not what happened. Instead, the United States obtained virtually every acre of Indian land at astoundingly low prices. This Article explains how the United States captured virtually all the gains from trade with the Indians.

After briefly discussing why customary practices are often efficient, ${ }^{166}$ the Article explains how the M'Intosh rule facilitated low-cost acquisition of Indian lands by stifling bidding by Americans for Indian land and making the United States a monopsonistic buyer. ${ }^{167}$ The decision, like the earlier colonial statutes, solved a collective action problem and left the Indians facing a single buyer assured of no competition. ${ }^{168}$

The United States, however, was not formally a monopsonist. If one tribe laid sole claim to a piece of land, then the advantage of being the only possible buyer was offset by the fact that there was only one seller. The parties are then trapped in what is called a bilateral monopoly, and the outcome of such bargaining games, where neither side can obtain competing offers, is uncertain.

Still the United States had many techniques for ensuring its victory in these bargaining games. On one extreme, an examination of the history of European-Indian negotiations reveals the willingness of the Europeans to use threats, and, rarely, force, to obtain land at bargain prices. While fighting was atypical due to its expense, it did set a ceiling on what the United States had to pay. ${ }^{169}$ The United States, however, did not have to resort to violence or even threats to lower the price of Indian lands. Its most powerful alternative was breathtakingly simple: settlement on the frontier. Settlers killed relatively few Indians in raids, massacres, skirmishes and the like. They killed many more by spreading endemic diseases like smallpox. ${ }^{170}$ Perhaps even more importantly, by clearing forests for agriculture, introducing European animals, and hunting at prodigious rates, they thinned the game animals on which the Indians depended for food, clothing, and other necessities. ${ }^{171}$ The colonies, and later the United States, passed

${ }^{166}$ See discussion infra Part II.A.1 (explaining the evolution of efficient customary rules).

${ }^{167}$ A monopsonist, the converse of a monopolist, is the sole buyer in a market, instead of the sole seller. See BLACK's LAW DICTIONARY 1023 (7th ed. 1999).

168 See discussion infra Part II.B (exploring European-Indian relations).

169 See discussion infra Part II.C (explaining the rarity of fighting).

${ }^{170}$ See discussion infra Part II.D.1 (explaining how depopulation by disease altered the terms of trade between Europeans and Indians).

171 See discussion infra Part II.D.2 (explaining how game-thinning altered the terms of trade between Europeans and Indians). 
a wide variety of laws to facilitate this process by encouraging and protecting settlers, and even squatters. ${ }^{172}$ On the other hand, settlers who precipitated hostilities made land acquisition more expensive, especially in terms of European lives; in response, the government attempted, with limited success, to reign in these rogue frontiersmen. ${ }^{173}$

This Part concludes by recharacterizing the process of efficient expropriation as an implicit exercise of the power of eminent domain. ${ }^{174}$ European immigrants had, under European valuations, a higher-valued use of the continent-intensive agriculture-but paid the Indians the European-calculated value of the land for its old use: hunting and light agriculture.

\section{A. Custom and the Efficiency Interpretation of M'Intosh}

\section{Evolution of Efficient Customary Rules}

Before examining in detail how M'Intosh and other legal rules facilitated efficient expropriation of Indians lands, it is worth pausing to consider how efficient customary rules arise in the first place. ${ }^{175}$ The rough and ready definition of an efficient rule is one that enables and encourages parties to maximize their joint production of wealth. ${ }^{176}$

Richard Epstein posits that customary rules are usually efficient when they arise among parties with frequent interactions (so-called repeat players) and the stakes in any individual case are small. ${ }^{177}$ In such circumstances, participants in an activity realize that they will gain in their numerous future dealings if they adopt an efficient rule (by the very definition of efficiency); there is not enough at stake in any one case to outweigh the sum of these expected future benefits.

${ }^{172}$ See discussion infra Part II.E.1 (explaining efforts to attract and reward settlers through the creation of legal rules).

${ }^{173}$ See discussion infra Part II.E.2 (explaining the negative externalities of lawless settlers, speculators, and traders).

${ }^{174}$ See discussion infra Part II.G (discussing the analogy between eminent domain and efficient conquest).

${ }^{175}$ See George L. Priest, The Common Law Process and the Selection of Efficient Rules, 6 J. LEGAL STUD. 65, 81 (1977) (positing that common law courts have a powerful tendency to adopt efficient rules). For possible shortcomings in this model, see POSNER, supra note 163 , at $614-15$ (noting several objections to the theory that common law courts have incentives to choose efficient rules).

${ }^{176}$ See POSNER, supra note 163, at 12-17 (discussing different definitions of efficiency).

See Epstein, supra note 138, at 11 (discussing the conditions in which customs emerge). 
Epstein further argues that when the context of a tort case indicates that customary practice is likely efficient (repeat players in consensual dealings, where the payoff at each interaction is relatively small), the court should defer to "the practices formulated by those who have powerful incentives to get things right."178

Once custom is accepted as controlling, it is no longer necessary for judges to guess what set of rules best accommodate the communities they serve. "That information is generated by trial and error from below, and those practices that survive have good claim to being beneficial (one could almost say efficient or wealth-maximizing) for the community at large."

Robert Ellickson has provided powerful historical examples and contemporary empirical evidence that customary practices in relatively close-knit groups are efficient, and that members of such groups generally rely on their customs even when formal legal rules provide seemingly more attractive rights and remedies. ${ }^{180}$

Unlike "conventional" custom, the rule of M'Intosh arose not from the everyday acts of European settlers, but instead from a long line of colonial statutes, regulations, and executive orders. This statutory source of custom explains why the rule against private purchases of Indian lands was likely efficient for European colonizers: it was rooted in democratic process. Assuming that democracy reflects the will of the governed, the fact that legislatures and executive officials from New Hampshire to Georgia adopted the same rule strongly supports the proposition that the rule reflected public desires. As the activities of the United Companies show, there were strong incentives for individual citizens to acquire choice lands directly from the Indians. From a societal point of view, however, such self-interested action would drive up the price of Indian land for all settlers. As discussed at length in Part II.B.1, the rule against such purchases might have harmed individual Europeans, but it helped minimize the total price paid for Indian lands. Settlers thus relied on legislation and regula-

${ }^{178}$ Id. at 24.

170 Epstein, Custom and Law, supra note 144, at 86. For a similar analysis, see Robert D. Cooter, Decentralized Law for a Complex Economy, 23 Sw. U. L. REv. 443, 445 (1994) (noting that "[t]he subject of this lecture is . . enacting custom") [hereinafter Cooter, Complex Economy], elaborated on in Robert D. Cooter, Struclural Adjudication and the New Law Merchant: A Model of Decentralized Law, 14 INTL REV. L. \& ECON. 215, 216 (1994) (noting that "[w]hen courts apply community standards, they find law, rather than making it").

${ }_{180}$ See ELIICKSON, supra note 148, at 184-206 (giving examples of customary practices that have developed in whaling and cattle communities). 
tion to solve a classic collective action problem-one of the primary efficiency gains derived from a government with coercive power.

Indians had no voice in the colonizers' governments, and thus it is not surprising that they were not a factor in the social calculus that resulted in the rule against private purchases of Indian lands. Both courts adopting customary practices, and commentators praising them, have been careful to point out that customary rules work well only in small, close-knit communities, where the custom has no negative effect on outsiders. ${ }^{181}$ Instead of facilitating free trade that would have maximized the joint product of both societies, European settlers adopted rules that maximized their own utility, regardless of Indian welfare.

\section{Contrasting Efficiency with Other Explanations of M'Intosh}

While the monopsonistic M'Intosh rule imposed costs on the Indians, this effect and the intent behind it are not obvious. Thus, both sides of the polarized debate on American-Indian relations, discussed in the Introduction above, find support for their respective views in Chief Justice Marshall's opinion. As noted in the Introduction, neither side provides a story that squares with basic historical facts, and M'Intosh is a case in point. ${ }^{182}$

At one extreme, Marshall could have given the Indians a full loaf: European title, with an absolute right to alienate to anyone. Beginning with Felix Cohen, scholars offering a benevolent interpretation of American Indian policy have described Marshall's opinion as a brilliant compromise between the political pressures to take Indian lands, and the immorality of outright expropriation. According to Cohen, Marshall "would accept neither horn of this dilemma .... [which] was neatly solved by Chief Justice Marshall's doctrine that the Federal

${ }^{181}$ See Ghen v. Rich, 8 F. 159, 162 (D. Mass. 1881) (adopting, for example, whaling custom as law, in part, because "[i] ts application must necessarily be extremely limited, and can affect but a few persons"); Epstein, Custom and Law, supra note 144, at 126 (noting that custom "works well in narrow domains"). Cooter says that a custom of cooperation among producers, resulting in a cartel, is clearly not entitled to judicial deference.

[M] embers of a business cartel can benefit each other by keeping prices high.

From the viewpoint of the cartel, discounting the price is "cheating." However, discounting benefits people outside the cartel more than it harms the members of it. Consequently, discounting is socially efficient, whereas the cartel is socially inefficient.

Cooter, Complex Economy, supra note 179, at 450 (emphasis added).

182 See supra text accompanying notes 1-12 (summarizing both sides of the debate). 
Government and the Indians both had exclusive title to the same land at the same time. ${ }^{\text {183 }}$ More recent commentators, while casting later Supreme Court decisions in a negative light, continue to view M'Intosh as a defense of Indian rights in the face of political pressure. ${ }^{184}$ An unstated assumption of these commentators is that judges and legislatures were willing to pay significantly more for Indian lands in order to salve the nation's conscience.

At the other extreme, Marshall could have given the Indians no loaf by declaring them truly tenants at sufferance subject to ejection at the will of the United States. The fact that Marshall also rejected this extreme position presents difficulties for those who portray American Indian policy as intentionally genocidal. Robert Williams makes one of the most forceful recent statements of this viewpoint, arguing that the only reason Marshall left the Indians with any rights is that " $[\mathrm{h}]$ is judicial task was merely to fill in the details and rationalize the fictions by which Europeans legitimated the denial of the Indians' rights in their acquisition of the Indians' America." ${ }^{\text {185 }}$ Williams fails to explain why Marshall, as a participant in grand theft of the continent, created a dual land tenure system vesting some rights in the Indians.

Marshall's decision to give the Indians half a loaf (or perhaps more accurately a quarter or an eighth of a loaf) thus presents difficulties for both the benevolent and the malevolent interpretation of the expropriation of America from the Indians. The remainder of this Part argues that M'Intosh is best explained as one element of a calculated, rational, unemotional effort to obtain Indian lands at the least cost. This analysis rejects the kindness imputed to Marshall (and the rest of the Justices who joined his unanimous opinion) by the benevolent school, and the truculence imputed by the malevolent school. The working assumption is that such a sweeping national policy to transfer wealth must be understood, at bottom, in terms of selfishness (economics), not benevolence or malevolence (morality or lack thereof). ${ }^{186}$

183 Cohen, supra note 5, at 48-49.

${ }^{184}$ See Wilkins, supra note 123, at 166-67 (stating that Marshall "cleverly reached a political/legal compromise" that protected Indians from outright expropriation); see also Henderson, supra note 23, at 105 (arguing that later Supreme Court cases undermined the nuanced and balanced approach of $M^{\prime}$ Intosh); Newton, supra note 22, at 1223 (indicating that M'Intosh represents "a brilliant compromise" by providing Indians with rights in the face of European rapacity).

185 WIIIAMS, supra note 12 , at 312 . For similarly dark readings of events leading up to the M'Intosh decision, see $i d$, at 185, 193-94, 196, 205, 207.

${ }^{186}$ Whether selfishness itself is good or evil is another classic normative debate; this 


\section{B. Governing European-Indian Relations: Presenting a United Front}

\section{United Front in Land Purchases}

The international discovery rule, along with the national rule of M'Intosh, ${ }^{187}$ created a two-tiered system to avoid competition for Indian lands. The first tier, the discovery rule, not only minimized physical conflict between European sovereigns, as emphasized by Chief Justice Marshall, ${ }^{188}$ but also ensured that once a nation had staked its claim, other nations would not meddle in affairs within the "discovered" region. $^{189}$

Other scholars have noted in passing that the second tier, barring citizens of the discovering sovereign from making private purchases, created a monopsony, but have not emphasized the importance of this custom, enshrined in M'Intosh, to the process of efficient expropriation. ${ }^{190}$ It is undoubtedly true from an individual perspective that

Article focuses on the positive implications of economic (selfish) behavior.

${ }^{187}$ Congress codified the rule against private purchases of Indian lands as part of the Trade and Intercourse Acts, discussed infra Part II.E.2.

${ }_{188}$ See supra text accompanying notes 2426 (discussing the discovery doctrine).

${ }^{189}$ While the discovery rule's attempt to minimize competition was efficient, at least from the European perspective, it had other effects that may or may not have minimized the cost of finding and expropriating aboriginal lands. The discovery rule does seem to encourage a wasteful race to establish rights. Expeditions across the oceans were costly propositions, yet countries may have incurred this and other expenses in order to establish property rights; this is also a potential problem with preemption (right to purchase based on settlement and improvements) and homesteading (right to title, without any payment, based on settlement and improvements), discussed infra Part II.E.1. For a vivid description of what seems an astoundingly wasteful race to establish rights among European nations, see THOMAS PAKENHAM, THE SCRAMBLE FOR AFRICA, 1876-1912, at xxi-xxv (1991). An earlier attempt by the Pope may have avoided competition, and such a wasteful race to establish rights, by assigning title before discovery. "The [papal] bull of Alexander VI in 1493 which divided the world between Spain and Portugal, for example, was principally designed to prevent an unseemly and dangerous scramble among Christian nations for the spoils of the newly discovered areas." Wilcomb E. Washburn, The Moral and Legal Justifications for Dispossessing the Indians, in SEVENTEENTH-CENTURY AMERICA: ESSAYS IN COLONIAL. HISTORY 15, 15 (James Morton Smith ed., W.W. Norton \& Co. Inc. 1972) (1959).

190 See Anderson \& McChesney, supra note 16, at 56 (noting in passing that the M'Intosh rule "made the United States a monopsonistic purchaser"); see also Jennifer Roback, Exchange, Sovereignly, and Indian-Anglo Relations, in PROPERTY RIGHTS AND INDIAN ECONOMIES 5, 18 (Terry L. Anderson ed., 1992) (discussing how state cessions to the federal government "facilitated the Continental Congress' continuance of the policy of monopolizing land purchases from the Indians"). Another scholar notes that the government's land monopsony was "bound up with issues of military security, diplomacy, and law enforcement." Springer, supra note 41, at 35. I will discuss what Springer meant by security, diplomacy, and law enforcement infra Part II.E, but conspicuously absent from this list of issues is the primary effect of monopsony: reducing 
"the prohibition on private land sales probably prevented many mutually beneficial transactions from taking place."191 From an American societal point of view, however, the rule of M'Intosh solved a collective action problem and permitted the nation to avoid expensive bidding wars for Indian lands.

To illustrate, consider a simplified version of a private acquisition of Indian lands. Assume that there are two tracts for sale, and two potential buyers. Both buyers face the following schedule of costs and revenues: ${ }^{192}$

- cost of two cents an acre to buy if they cooperate and do not bid against each other, but one dollar an acre if they bid against each other; and

- revenue of three dollars an acre from reselling small lots to settlers.

If the players cooperate (stick to an agreement to bid low), they each agree to buy one tract. One assumes if they compete (either never agree to both bid low, or both defect from such an agreement), they likewise each obtain one tract. If one cooperates while the other competes, the defecting competitor obtains both tracts. Based on these numbers, the players' payoffs are determined by the interaction of their decisions to cooperate or compete.

the price a buyer pays.

Roback, supra note 190, at 19.

192 These costs and revenues are loosely based on historical data. See infra text accompanying note 490 (describing how Indians typically received about two cents an acre or less for land while the statutory minimum price charged for land was two dollars an acre). 
Player 2

\begin{tabular}{|c|c|c|}
\hline & Cooperate & Compete \\
\hline Cooperate & 298, 298 & 0,400 \\
\hline Compete & 400,0 & 200,200 \\
\hline
\end{tabular}

(payoffs in cents: Player 1, Player 2)

\section{Figure 1}

This presents the players with the classic prisoners' dilemma. ${ }^{193}$ Without some mechanism to enforce an agreement to cooperate, both buyers are likely to defect and bid against each other for both tracts. While this competition may have been optimal considering the welfare of Indians as well as the Americans, this Article hypothesizes that American laws sought to maximize only American welfare. If so, this potential competition is disastrous for Americans, as the Indians receive a substantial share of the value of their lands. If American bidders cooperate, their net wealth increases by almost six dollars; any degree of competition reduces this surplus by two dollars-money that goes directly to the Indians. The United Companies, for instance, faced no rivals for the lands they sought to purchase, but had they earned fat profits, more competitors would inevitably have begun bidding for Indian lands.

M'Intosh provided a neat solution to this dilemma by establishing the United States as the sole purchasing entity. Not only did the holding solve the collective action problem, but it did so without imposing any administrative costs on the government. ${ }^{194}$ Any private party so rash as to violate the rule, like the United Companies, ended up with an unmarketable title, and a subsequent purchaser from the United

${ }^{193}$ See DOUGLAS G. BAIRD ET AL., GAME THEORY AND THE LAW 33-35 (1994) (explaining that the Prisoners' Dilemma focuses attention on collective action problems, where the parties do best if they cooperate, but at the same time they lack mechanisms to credibly and enforceably commit to cooperative behavior).

${ }^{194}$ This stands in stark contrast to the extremely high expense, amounting to impossibility, of regulating many other acts of those on the frontier. Such prohibitive costs often hindered the least-cost expropriation of Indian lands. See infra Part II.E.2 (discussing how actions of some frontiersmen, such as squatting on Indian lands, had negative external effects that imposed costs on the rest of the nation). 
States, like William McIntosh, could file suit (or, as in M'Intosh, defend against suit) to clear title. ${ }^{195}$

Marshall does not mention creating a monopsony; as discussed in Part II.A.1, judges often adopt customary practices as law without realizing their efficiency. At some level, however, the courts did realize the importance of M'Intosh. The trial court, and then the Supreme Court, decided a case that minimal investigation would have revealed was feigned. Marshall's opinion for the unanimous Court chose the broadest rule possible, laying down a national standard, instead of relying on colonial or British law that the opinion itself declared valid. ${ }^{196}$ Although Congress could have legislatively reversed the decision, M'Intosh fostered collusion in the purchasing of Indian lands. There are no records of subsequent litigation attempting to reverse the case, and no records of subsequent private purchases from the Indians.

The opinion's focus on incentives going forward, rather than on the fairness of events that had already transpired, is further evidence that the courts grasped the efficiency motivation for the custom against private purchases of Indian lands. Ironically, despite the detrimental effect of the case on Indian welfare, the real winners of M'Intosh were the Illinois and Piankashaw Indians. The losing plaintiffs found the claims they inherited worthless. The victorious defendant, William McIntosh, presumably paid the United States fair value for the lands and derived little further benefit from the case. ${ }^{197}$ The tribes, however, sold the lands twice: first in 1773 and in 1775 to the Illinois and Wabash Companies, then from 1803 to 1809 to the United States. The United Companies repeatedly beseeched Congress to avoid double payment to these double grantors, but the legislature, and then the Supreme Court, found this equitably sound argument unconvincing. ${ }^{19}$

As discussed above in Part I.C.3, Marshall told the plaintiffs that, under the dual land tenure system, they must seek a remedy from the

195 The rule did impose negotiation and other transaction costs on the federal government, but as discussed infra Part II.B.2, the government appears to have had negotiating advantages that were unavailable to any private party.

${ }^{196}$ See M'Intosh, 21 U.S. (8 Wheat) at 598-600.

${ }^{197}$ The decision did remove a small blotch from McIntosh's title, but given the number of people buying lands based on United States patents that overlapped with the United Companies' claims, their potential conflicting claim was not seen as much of a threat. The author could find no evidence that land intersecting the Companies' tracts sold at a discount compared to similar land elsewhere.

${ }^{198}$ See supra text accompanying notes 74-76 (discussing the United Companies' arguments against paying the tribes twice for the same land). 
Indians, under whom they held title. Marshall, however, virtually admitted that the Court would find no remedy since there was no Indian forum. If he had been concerned with equity, Marshall could have (1) ruled in favor of the plaintiffs, (2) directed the United States to refund McIntosh's money, and (3) instructed the United States to pursue the Illinois and Piankashaw tribes for a remedy, perhaps taking some of their western reservation lands. The United States government alone was capable of disgorging the Indians' unjust gains from selling the same lands twice. Instead, the holding of the case left the double grantors with double proceeds, apparently a necessary evil in reaffirming a custom that helped reduce the price Americans paid for Indian lands.

M'Intosh, of course, was a fleeting and pyrrhic victory for two small tribes. Indians generally realized that America's monopsony worked to their detriment and tried to deny the existence of any such exclusive right to purchase.

Brothers: You have talked, also, a great deal about pre-emption, and your exclusive right to purchase Indian lands, as ceded to you by the King, at the treaty of peace.

Brothers: We never made any agreement with the King, nor with any other nation, that we would give to either the exclusive right of purchasing our lands; and we declare to you, that we consider ourselves free to make any bargain or cession of lands, whenever and to whomever we please. If the white people, as you say, made a treaty that none of them but the King should purchase of us, and that he has given that right to the United States, it is an affair which concerns you and him, and not us; we have never parted with such a power. ${ }^{199}$

These protestations could have no effect as long as the British respected their treaty with the United States (preventing international competition), and the United States in turn effectively refused to recognize Indian deeds obtained by its citizens (preventing intranational competition). All the willingness in the world to sell to the highest bidder is irrelevant if there is only one bidder. Indians selling land after M'Intosh suffered much the same way consumers would in the absence of antitrust laws. Just as a price-fixing agreement between manufacturers $A$ and $B$ can harm consumer $C$ despite the fact that $C$ is not a party to the deal, the customary agreement among Americans not to bid against each other for Indian lands, embodied in M'Intosh,

199 Answer to Speech by the Commissioners (Aug. 16th, 1793), reprinted in AMERICAN STATE PAPERS, supra note 81, 1 INDIAN AFFAIRS 356, 356 (1832). 
reduced Indian welfare by lowering the price Indians received for their lands without requiring any consent from those harmed.

Refusing to recognize Indian deeds also helped clarify land titles. ${ }^{200}$ It may have been expensive to mediate conflicts among Americans running deep into the woods and obtaining potentially overlapping deeds. Determining whether or not such deeds were fraudulently obtained might have been difficult as well. ${ }^{201}$ Divergences between the two cultures' understandings of land tenures may have contributed to such difficulties. For example, the European emphasis on absolute power to use and exclude forever was at odds with the Indians' frequent use of more limited usufructuary land rights). Yet governments could have solved these difficulties by simply placing the burden on private purchasers to prove that they obtained clearlydemarcated lands in fair sales. To assure that the deeds obtained were not fraudulent, the government could have required, for instance, that all purchasers negotiate at federal posts, as Murray did in obtaining the Illinois Company deed. Standard recording acts could have resolved competing claims. Standard rules on unclear land descriptions could have addressed problematic land descriptions in Indian deeds. Alternatively, if the United States was not worried about paying market price for Indian lands, but rather only about clarity of titles, it could have appointed itself sole auctioneer of Indian lands. Whenever the Indians decided to sell, agents of the United States would then have conducted the sale fairly, made sure there were not conflicting grants, deducted a portion of the proceeds for its administrative expenses, and forwarded the remainder of the winning bids directly to the Indians. Thus, while a federal monopsony did enhance clarity of land titles, it did not seem to lie at the heart of the customary practice upheld in M'Intosh.

The colonists did not stumble at random onto the efficient custom adopted in M'Intosh. Colonial policymakers realized the advantages of preventing competition for Indian lands, and they did not stop at curbing individual land transactions: "From the earliest colonial period, the English Crown adopted a policy of attempting to centralize and monopolize contact with the natives." ${ }^{202}$ As Chief Justice Marshall noted later in another important Indian law case, "[t]he

${ }^{200}$ See Telephone Interview with Professor Robert Ellickson, Yale Law School (Feb. 4, 1998).

${ }^{201}$ See JENNINGS, supra note 10, at 130 (discussing "endless litigation over purchase of fraudulent titles" in colonies before they banned private purchases).

${ }^{202}$ Roback, supra note 190, at 11. 
whole intercourse between the United States and [Indian nations], is, by our constitution and laws, vested in the government of the United States." 203

In addition to restraints on individuals, the historical record is replete with arrangements designed to solve the collective action problem among colonies and later states-the "federalism" dimension of presenting a united front. The land monopsony seems to have been one of the central purposes of the United Colonies of New England, an early American confederation formed in 1643. "Six of the eight commissioners, two from each colony, had to authorize action, so opportunistic scrambling for Amerindian lands could be stalled by rival colonies." ${ }^{204}$ A century later, the British barred private purchases of lands in the Proclamation of 1763 in part to prevent competition in the acquisition of Indian lands. In proposing national control over Indian relations in the Articles of Confederation, Ben Franklin declared that "[a]bove all else, rivalries between colonies in treating with the Indians had to be avoided."205 The Articles, however, left the States with complete control over the Indians within their borders. This excessive division of power was one of the reasons the nation adopted a new Constitution that clearly and unequivocally made the national government master of all dealings with the tribes. ${ }^{206}$ Executive officials brooked no violation of these governmental prerogatives. $^{207}$

${ }^{203}$ Worcester v. Georgia, 31 U.S. (6 Pet.) 515, 561 (1832).

204 IAN K. STEELE, WARPATHS: INVASIONS OF NORTH AMERICA 95 (1994).

205 Francis PaUl Prucha, AMERICAN INDIAN Treaties: THE History of a POLITICAL ANOMALY 38 (1994).

${ }^{206}$ Article IX of the Articles of Confederation gave the United States control only over Indians in the territories outside the established states. See ART. OF CONFED. of 1781, art IX (granting the power to regulate "the trade and managing all affairs with the Indians, not members of any of the states, provided that the legislative right of any state within its own limits be not infringed or violated"). Note that even this arrangement prevented competition among governments, since it vested exclusive power to deal with a given tribe in either one state or in the national government. The Indian Commerce Clause of the Constitution of 1789 removed even this limited division of power. See U.S. CONST. art. I, \& 8, cl. 3 (granting Congress the power to regulate commerce with Indian Tribes).

Despite this provision and a series of congressional acts regulating trade and intercourse with the Indians, some eastern states continued their colonial practice of dealing directly with the Indians. The federal government did not intervene. "These state actions provided the fodder for the rash of eastern Indian land claims litigated in federal courts over the [1970s and 1980s]." Robert N. Clinton, The Proclamalion of 1763: Colonial Prelude to Two Cenluries of Federal State Confict over the Management of Indian Affairs, 69 B.U.L. REv. 329, $372-73$ (1989).

${ }^{207}$ See, e.g., ROBERT V. REMINI, ANDREW JACKSON AND THE COURSE OF THE 
The importance of presenting a united front suggests a different interpretation of Cherokee Nation ${ }^{203}$ and Worcester ${ }^{209}$ which, together with M'Intosh, comprise the "Marshall trilogy" on Indian law. Focusing on sympathetic dicta, many scholars have suggested that these cases embodied a sympathetic and fair-minded approach to dealing with the Indians that later opinions overlooked. ${ }^{210}$ Frickey argues that, while Marshall's $M$ 'Intosh opinion may have recognized unsavory colonialism as to past events, when taken together with Cherokee Nation and Worcester, Marshall attempted to soften colonialism with constitutional-style rules that limited the ability of the other branches to exploit the Indians. Frickey reads the Marshall trilogy as an implicit message to the other branches of government and the nation that they "should help those poor Indians."

Whatever Marshall pontificated about in his extensive dicta, the holdings of the two cases clearly served the purpose of maintaining a united front in Indian relations. Cherokee Nation held that the Supreme Court did not have original jurisdiction over a lawsuit filed by Indians since Indian tribes were not the type of foreign "States" contemplated in the Supreme Court's grant of original jurisdiction in the Constitution. ${ }^{212}$ By deeming Indian tribes "domestic dependent nations, ${ }^{213}$ Marshall ensured that neither foreign powers nor any of the several states would meddle in Indian affairs. In Worcester, the Court

AMERICAN EMPIRE, 1767-1821, at 422 (Harper \& Row 1977) (1817) (providing that upon becoming governor of the chaotic Florida Territory in 1821, "Jackson arrested all white men who treated with the Indians without proper authorization. One thing he would not abide was a 'meddlesome' white man undercutting his policy."). Plaintiff William McIntosh withdrew a suggestion that private citizens contact Indians about the likelihood of hostilities, making it clear that he "did not intend to interfer[e] with the poceedings [sic] of the Governor," who had exclusive power over Indian affairs. Letter from James Johnson to Nathaniel Ewing (June, 1810), reprinted in 8 TERRITORIAL PAPERS, supra note 31, at 29 (1939).

${ }^{203}$ Cherokee Nation v. Georgia, 30 U.S. (5 Pet.) 1 (1831).

${ }^{209}$ Worcester v. Georgia, 31 U.S. (6 Pet.) 515, 515.

210 See supra notes 31-36 and accompanying text (noting that the American government paid for almost all of the land acquired from the Indians, even though the law did not require it).

211 Frickey, supra note 133, at 424.

212 See U.S. CONST. art. III, § 2 ("The judicial power shall extend to all Cases ... between a State, or the Citizens thereof, and foreign States, Citizens, or Subjects.").

${ }^{213}$ Cherokee Nation, 30 U.S. (5 Pet.) at 17 (" $[$ T] acknowledged boundaries of the United States ... may, more correctly, perhaps, be denominated domestic dependent nations. They occupy a territory to which we assert a title independent of their will, which must take effect in point of possession, when their right of possession ceases."). 
held, under the clear language of the Constitution (reversing the Articles of Confederation), that the State of Georgia had no power to deal directly with the tribes within its borders. By preserving a unitary entity to deal with the Indians, Marshall's opinions helped the United States continue to buy Indian land cheaply. ${ }^{214}$

\section{The Bargaining Game}

While M'Intosh limited the number of bidders for Indian lands to one legal entity, it would be rash to conclude that this created a monopsony. If a tribe had an exclusive claim to a piece of land, the value of being a single buyer was counterbalanced by the existence of a single seller: the United States then could not pit competing sellers against each other.

Dealings of this sort, with only one party on each side of a potential transaction, are called "bilateral monopolies" or "bargaining games." The basic schema is that the two parties are interested in making a deal, and there exists a range of prices acceptable to both. Marine salvage law contains a vivid example. Imagine that the good ship Rescuer comes across the storm-damaged Distress. The Distress is incapable of moving and carries a very valuable cargo, say, gold, worth $\$ 1,000,000$. No other ships are likely to happen by (thus ensuring that this is indeed a bilateral monopoly). The expense to the Rescuer of assisting the Distress, accounting for all costs and risks, is $\$ 10,000$. Thus, the Rescuer would be happy to perform the rescue services for any higher amount. The Distress, facing a total loss, is better off paying anything up to $\$ 1,000,000$. If the parties are roughly aware of these facts, there is much room for haggling, bluffing, and all the other fine points of negotiating. The bottom line is that both sides know the other side is better off agreeing to extreme terms than none at all. ${ }^{215}$

There is no exact "solution" to such bargaining games. Unlike "normal" markets where supply and demand, created by numerous

${ }^{214}$ President Jackson's infamous refusal to enforce Marshall's decision against the State of Georgia might appear to undermine the unifying, nationalist holding. However, Jackson's refusal to protect the Indians against the depredations of the Georgia state government may only indicate that the nation approved of the State's policy, and in effect relied on Georgia, as an agent, to further national policy. Marshall's decision gave the federal government the power to prevent state actions that were inconsistent with the national interest; Jackson merely chose not to exercise this power against Georgia.

${ }_{215}$ Bilateral monopolies are ubiquitous; other examples include workers and firms, when workers have firm-specific skills; neighboring property owners negotiating an easement; and relations among owners of a closely held corporation. 
competing sellers and buyers, dictate a Pareto-optimal price, any outcome between $\$ 10,000$ and $\$ 1,000,000$ is plausible for the example in the previous paragraph. The relative bargaining talents of the parties will ultimately determine the outcome. There may, however, be other factors such as time-pressure that affect the outcome. For instance, if the Distress were sinking and it were a matter of life and limb, the Rescuer would be likely to garner more favorable terms. ${ }^{216}$

The next two Parts catalog a host of techniques the United States used in this bargaining game to minimize the price it paid for Indian lands. Parts II.B.2.a-.b discuss the techniques in decreasing order of acceptability under contract law and voluntary exchange, starting with bluffing, surely a legal practice, and ending with physical intimidation and threats, surely grounds for rescinding contracts at common law. ${ }^{217}$ Part II.B.2.c discusses why the United States's superior unity and governance translated into this catalog of bargaining advantages over the Indians. Finally, Part II.B.2.d argues that the strange mix of bargaining techniques-some of which were consistent with voluntary exchange, while others not-fits the hypothesis of efficient conquest well.

\section{a. Bargaining "Tricks" Colorably Consistent with Contract Law}

A common negotiating technique is to pound a fist on the table and storm out of the room, declaring a (false) intention never to return, in the hope that the other side, realizing a bad deal is better than no deal, will cave in. This is undoubtedly a legally accepted practice in voluntary negotiations. The United States frequently employed such bluffs to gain an advantage in bargaining to purchase Indian lands. For example, in 1786 the United States implied it would attack the Shawnees if they refused to the proffered terms, despite the Secretary of War's later admission that the nation was "utterly unable to maintain an Indian war with any dignity or prospect of success."218

Perhaps the most potent ploy for gaining the upper hand in negotiations with Indians was exploiting divisions, both among the several tribes and within each tribe. European colonial powers had long used

216 See DAVID M. KREPS, A COURSE IN MICROECONOMIC THEORY 551 (1990) (discussing bargaining in a bilateral monopoly).

${ }^{217}$ RESTATEMENT (SECOND) OF CONTRACTS, §§ 174-76 (1987).

218 PRUCHA, supra note 205, at 54 (quoting statement of Henry Knox, Secretary of War). I will discuss the use of threats below in Part II.B.2.b; here the focus is on bluffing-making representations that the United States was capable of prosecuting a war when in fact it could not. 
such divide and conquer techniques to forcibly take Indian lands. "[T]he [Spanish] conquistadors, efficient killing machines though they were, did not conquer Mexico and Peru unaided. Native allies were indispensable. In a sense, Spanish armed conquest was a judo trick by which Europeans, assisted by the pox and the plague, used the Indians' own strength to overthrow them.",219

The United States repeatedly exploited fissures among and within tribes to obtain land cheaply, usually without resorting to force. From the first days of the Republic, Congress counseled its Indian agents to "deal with each Indian tribe or nation as separately as possible"220 and "insisted that the tribes were to be kept separated so that negotiations would be easier." and refusing to sell lands, Secretary of War Knox successfully cleaved the powerful Iroquois from such an alliance "by remedying their complaints" about, inter alia, American land claims and encroaching settlers. ${ }^{222}$

The United States preyed mainly on two sources of disunity among the Indians. First, the United States fanned the flames of longstanding animosities between various groups. For instance, General St. Clair purposefully negotiated separately with the Six Nations and the Great Lakes tribes because there was "a jealousy that subsisted between them, which [he] was not willing to lessen by appearing to consider them as one people"-St. Clair even thought, if need be, he could "set them at deadly variance. ${ }^{223}$ The United States at times paid little in hard cash for land, instead offering to protect weak tribes against strong enemy neighbors or co-tenants. This tactic helped reduce the amount William Henry Harrison agreed to pay to the Kaskaskias for the lands in southern Illinois that they had previously conveyed to the Illinois Company. ${ }^{224}$

219 JENNINGS, supra note 10 , at 33.

${ }^{220}$ Charles Judah Bayard, The Development of the Public Land Policy, 1783-1820, with Special Reference to Indiana 48 (1956) (unpublished Ph.D. dissertation, University of Indiana (Bloomington)) (on file with author).

221 Id. at 85-86.

222 Robert F. Berkhofer, Barrier to Settlement: British Indian Policy in the Old Northwest, 1783-1794, in THE FRONTIER IN AMERICAN DEVELOPMENT 249, 270 (David M. Ellis ed., 1969).

${ }^{223}$ Letter from Governor St. Clair to the President (May 2, 1789), in 2 THE ST. Clair PAPERS: ThE LIFE AND Public Services of ARThur St. Glair 111, 113 (William Henry Smith ed., 1882).

${ }^{224}$ See WRITINGS OF JEFFERSON, supra note 165, at 375 (noting that the Kaskaskias "are now but a few families, exposed to numerous enemies, and unable to defend themselves, and would cede lands in exchange for protection"). 
Second, the United States manipulated the conflicting and unclear tribal claims in order to buy land cheaply. "Frontier authorities often found it expedient to bargain with one nation for lands claimed or actually occupied by another." ${ }^{225}$ Even in cases in which all sides agreed that a number of tribes held land in effect as co-tenants, the United States was able to drive a wedge between the owners. William Henry Harrison was a master of this technique.

Harrison played the divided villagers against each other, getting substantial cessions. Because villages often contained members of several tribes and because different tribal groups shared common areas, one group rarely had exclusive claim to the land. If Harrison induced representatives of one group to make a cession, then others had to follow or else risk getting no payments at all for the land.... [C] hiefs signed from fear that if they refused, chiefs of other villages would gladly make the cessions in their stead.

Harrison employed the same technique to obtain the Piankashaws' interest in the lands they had previously conveyed to the Wabash Company.

The cession of 1804 in southwestern Indiana from the Delaware and Piankishaw was obtained by [divide and conquer]. Both tribes claimed the area but would not consider releasing their title. Delaware acquiescence was first obtained. The Piankishaw, realizing the tenuousness of their claim, and fearing the loss of additional annuities and goods that might otherwise accrue from a cession on their part gave consent less than a fortnight later in a separate treaty.

There was no end to the theories that the British, and later the Americans, conjured up to place title in the hands of a tribe that was willing to sell, and sell cheaply. For instance, after the Proclamation of 1763 and Pontiac's Uprising:

[T] he British partially resurrected the old doctrine of Iroquois ownership of the lands along the Ohio River [based on conquest]. This

${ }^{225}$ JACK M. SOSIN, THE REVOLUTIONARY FRONTIER, 1763-1783, at 84 (1967). In a somewhat comical example of what must have been a specious claim, President Jefferson told William Henry Harrison that he had "heard there was still one Peoria man living, and that a compensation, making him easy for life, should be given him, and his conveyance of the country [referring to a large tract in central Illinois] by a regular deed be obtained." MOSES DAwSON, A HistorICAL NARRATIVE OF THE CTIL \& MIITTARY SERVICES OF MAJOR-GENERAI WIIIIAM H. HARRISON 112 (1824).

${ }^{226}$ WHITE, supra note 62 , at 474, 496. The Kaskaskias' 1803 cession was a notorious example of such practice. See id. at 474 n.6 (noting that although the Kaskaskia tribe at the time numbered only 30 men, women, and children, they ceded southern Illinois to the United States).

${ }^{227}$ Smith, supra note 37 , at 245 . 
opened up the possibility of the Iroquois, ceding away the land of their "dependents," as they had before.

Another argument held that "the French had reached Illinois country before the Illinois [tribes] themselves had .... and thus had prior claim to the land that had, by right of conquest, descended to the British king." 229

Sometimes the United States did not even rely on preexisting divisions or muddled claims; it merely isolated resistant tribes by making deals with their neighbors. During his negotiations with the southern tribes in the aftermath of the War of 1812, Andrew Jackson "decided to treat the Indians separately. By dividing the tribes he believed he could weaken their resistance to his demands. He began with the Cherokees because he anticipated 'much difficulty' with the Chickasaws.... An initial success with the Cherokees, therefore, would strengthen his negotiating stance with the Chickasaws."

The "divide and conquer" strategy eroded the price Indians received for their lands in two ways. First, by introducing competition among sellers, especially co-claiming tribes, the United States was able to convert a bilateral monopoly into something more akin to a monopsony. ${ }^{231}$ It might seem that tribes with co-tenancy interests who did not sell simply could have remained on the land. Given the United States's policy of making some payment to almost any tribe with even a colorable claim, the fact that one co-tenant received a payment would not seem to diminish the right of the other co-tenant to occupy the land. ${ }^{232}$ The United States, however, usually paid less to late-

${ }^{228}$ WHITE, supra note 62 , at 308 . It is unclear whether or not the Indians recognized title by conquest amongst themselves. See Johnson v. M'Intosh, 21 U.S. (8 Wheat.) 543, 573 (1823) (noting that Algonquian Indians in Illinois and surrounding regions rejected Iroquois claim to title by conquest); WHIIE, supra note 62 , at 150-55 (describing Iroquois claims to Illinois land based on conquest). Perhaps more telling is the fact that British officials did not believe in it.

General Gage thought [the] myth of Iroquois conquest had been useful enough in negotiations with the French, but he did not believe that the Iroquois could negotiate away Shawnee lands on the basis of such a conquest. "If we are to search for truth and examine her to the Bottom, I dont [sic] imagine we shall find that any conquered $\mathrm{Na}$ tion ever formaly [sic] ceded their Country to their Conquerors, or that the latter even required it." Id. at 352 (quoting correspondence of General Gage). The Shawnees disputed the right of the Iroquois to cede their land. See id. at 354 (describing the Shawnees' attempt to oppose the treaty by which the Iroquois had ceded their land to the British).

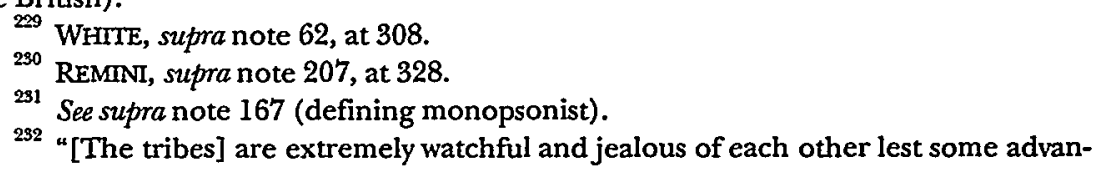


settling tribes. Moreover, as explained in Part II.D.2 below, once settlers approached Indian lands, their activities reduced the stock of hunting prey dramatically and rendered the land of little value to the tribes. Accordingly, tribes were pressured into early sales of land to the United States.

The United States employed a version of "divide and conquer" within tribes as well as among them. "If there was not unanimity within a tribe itself, assent would be obtained from those chiefs who were willing, thus giving the United States a wedge and also weakening the tribal resistance. ${ }^{\text {233 }}$ General St. Clair failed to purchase any lands in Indiana or Illinois since he could not identify any leaders with sufficient certainty. His successor William Henry Harrison, however, "seldom troubled himself about either the justice of the claims of the contracting party or the representative character of the chiefs, if signatures to a treaty could be obtained. ${ }^{234}$

Sowing division among the other side in negotiations is generally permissible under the common law of contracts. In labor talks, a firm bargaining with many employees may try and to lure some back in the hopes of undermining the strike. Symmetrically, a union striking against multiple employers may make a deal with one employer in the hopes that others will follow. Harrison's method of exploiting intratribal division by striking deals with any member who would sign, while valid as a matter of contract law, may have violated principles of agency law: there appears no plausible basis for imputing to unempowered chiefs (agents) the authority to bind their tribes (principals).

Bribery, a similar trick that exploited divergent incentives among tribe members, is also consistent with voluntary exchange. However, bribery is beyond the range of acceptable tactics under the common law of agency. ${ }^{235}$ Indian leaders time and again proved to be disloyal

tage should be obtained in which they do not all participate." Letter from William Henry Harrison to Secretary of War Dearborn, Feb. 26, 1802, in DAwsoN, supra note 225 , at 19.

${ }_{233}$ Smith, supra note 37 , at $245-46$.

${ }^{234}$ ALVORD, supra note 25, at 416. General St. Clair "had been ordered to purchase cessions from the Indians, but on his first visit he was unable to discover any nation with a clear title to the southern lands of Illinois." Id. William Henry Harrison, who negotiated all the major treaties discussed in this subsection, had no such compunction, "showing a readiness to enter into negotiations with any faction or isolated band of Indians who would consent to a relinquishment of land titles." Id.

${ }_{235}$ Under the duty of loyalty as defined by the common law of agency, agents must "act solely for the benefit of the principal in all matters connected with the agency," and "an agent who makes a profit in connection with transactions conducted by him on behalf of the principal is under a duty to give such profit to the principal." RESTATEMENT (SECOND) OF AGENCY $\$ \S 387-88$ (1958). Thus an agent (such as a chief) 
agents to their principals (tribe members), and the United States did not seem to show any aversion to taking advantage of this breach of duty. For example, President Jefferson advised Harrison to bribe chiefs in purchasing Illinois and Indiana lands, and Harrison did so effectively. ${ }^{236}$ The United States resorted to bribing virtually all the tribes from which it bought lands; "such methods of obtaining Indian agreement had become the rule rather than the exception."237

\section{b. Fraud, Overawing, and Threats}

In addition to bribery, the United States consciously engaged in "ruse, subterfuge, circumvention, and outright fraud to achieve through chicanery, under the cloak of voluntary cooperation, a continued stream of land cessions." ${ }^{\text {"238 }}$ The Indians were, of course, aware of such tricks. "The Americans were, the Shawnees argued, inevitably 'deceitful in their dealings with ... the Indians.' Their promises of benevolence were their most potent weapons." ${ }^{\text {"239 }}$ Outright fraud, of course, cannot form the basis for enforceable contract rights under Anglo-American law.

The United States also tried to overawe Indians in order to obtain their lands more cheaply.

Almost from the day whites arrived in the New World... [Europeans] shipped Indians back to Europe to impress them with the extent of white technology and population, then returned them "with the expectation that upon their return they would spread the gospel of European superiority throughout their native villages." Whites frequently demonstrated

representing a principal (such as a tribe) who takes a bribe has not acted solely for the principal's benefit and is obligated to remit the bribe to the principal.

${ }^{236}$ See WRITINGS OF JEFFERSON, supra note 165, at 376 (stating that "it would be easy to solicit and bring over by presents every individual of mature age"); Smith, supra note 37 , at 246 ("After receiving a special annuity in the preliminary negotiations for the Treaty of June 7, 1803, Little Turtle, who had until then opposed any cession, became inclined to favor one.").

${ }^{237}$ HORSMAN, supra note 90, at 140; see also id. at 125 (finding that Cherokees were "brought to reason' ... by the bribery of one or two influential chiefs"); id. at 140 (predicting that "moderate presents to some of the most influential Characters, will be deemed sufficient" to obtain an easement to build a road); REMINI, supra note 207, at 329,330 (documenting several occasions on which Jackson resorted to bribery in order to obtain land). Jackson emphasized the importance of covering up such transactions: "Secrecy is necessary, or the influence of the chiefs would be destroyed." Id. at 330.

${ }^{238}$ MiCHAEL D. GREEN, THE POLITICS OF INDIAN REMOVAL: CREEK GOVERNMENT \& SOCIETY IN CRISIS 50 (1982).

${ }^{239}$ WHrTE, supra note 62 , at 459 (citation omitted). 
their technology peacefully to impress Indians with the pointlessness of war. $^{240}$

While some techniques for impressing the tribes contained only the hint of a threat, more commonly, the United States and it predecessors overawed the Indians with direct displays of military might.

[While t] he posts were small, and the number of troops that could be squeezed from the civilian-minded and economy-conscious Congress was always inadequate, ... Indian agents ... who carried on the relations between the government and the Indians always did it under the shadow of the authority and protection of a nearby military garrison. ${ }^{241}$

Furthermore, the United States recognized that "[a] display of force or demonstrations of potential military strength were effective persuaders at conferences and negotiations either bringing awe, respect, fear, or a realization of futility to the Indians. ${ }^{242}$

While impressing a bargaining foe with economic might may be legally permissible (for example, in a merger proposition made by a large competitor to a smaller one), employing armed agents to suggest that physical harm is the alternative to striking a deal makes a strong case for duress. The United States, however, often went beyond mere displays of force and employed direct intimidation and overt threats when "negotiating" land cessions. Although it was only a bluff, the Shawnee in $\mathbf{1 7 8 6}$ were "warned that the United States intended to hold firm to its conditions and that refusal of the terms would mean war. 'The destruction of your women and children[,] or their future happiness ... . depends on your present choice. Peace or war is in your power."

In negotiating with the Choctaws at Doak's Stand in 1820, Jackson

found the Indians generally opposed either to ceding or exchanging any land. The few Choctaws who favored a treaty were compelled to be silent, and every chief threatened with death if he consented to sell or exchange an acre.... [After long and tough negotiations] Jackson resorted to threats . . . . He warned them of the loss of American friendship; he promised to wage war against them and destroy the

240 Anderson \& McChesney, supra note 16, at 58-59 (quoting JAMES AXTELL, AFTER COLUMBUS: ESSAYS IN THE ETHNOHISTORY OF COLONIAL NORTH AMERICA 140 (1988)).

241 PRUCHA, supra note 6, at 62.

${ }^{212}$ Smith, supra note 37 , at 246.

${ }^{243}$ PRUCHA, supra note 205, at 52 (quoting 2 THE OLDEN TIME 523-24 (Neville B. Craig ed., Kraus Reprint Co. 1976) (1848)). 
Nation; finally he shouted his determination to remove them whether they liked it or not. ${ }^{24}$

President Monroe agreed that "if the Indians did not voluntarily submit to the civilizing programs, compulsion would have to be resorted to." 245

Tribes wanted what any bargainer wants: a fair price. During Harrison's 1809 negotiations in Indiana, one tribe, the Miami, initially adamantly refused to sell any land, declaring that they must end "the encroachments of the whites who were eternally purchasing their lands for less than the real value of them" and vowed to sell only "for the price that it sells among[]st yourselves [the Americans]." ${ }^{246}$ The Miami were simply trying to obtain a portion of the gains from trade with the Americans. Harrison predictably replied with a veiled threat: he would "extinguish the council fire" if the Miami would not agree to the substance of his terms. ${ }^{247}$

Threats, of course, are antithetical to the voluntary exchange that supposedly legitimized American purchases of Indian lands. They undermine the essence of lawful negotiation: the right of both sides to simply leave the room, refuse to cut a deal, and retain whatever property rights they possessed ex ante. "The pressure [on Indians to cede lands] was such that it made a farce of the oft-repeated assertion that the Indians were equally free to sell or refuse to sell."248 One of the reasons given for a proposed military expedition against the Piankashaw and other Wabash tribes was
"their refusing to treat with the United States when invited thereto." The Indians were fighting to resist pressure on their lands, and treaties with the American government almost invariably resulted in the confir- mation of cessions or demands for new ones; yet when the Indians re- fused to negotiate, this was used as a reason for a military expedition. Though Knox had asserted that the Indians held the right of soil and could choose whether or not to sell their lands, this concept of free choice broke down under the pressure of the frontier advance.

\footnotetext{
${ }^{244}$ REMINI, supra note 207, at 393-95 (internal quotations omitted).

245 PRUCHA, supra note 205, at 154.

${ }^{246}$ Smith, supra note 37, at 226 (quoting JourNal OF THE PROCEedings 13, 18 (J.L. Heinemann ed., 1910) (1809)) (emphasis added).

247 Id. at 227 (citing JOURNAL OF THE PROCEEDINGS, supra note 246, at 19).

${ }^{248}$ HORSMAN, supra note 90, at 126. See supra Part I.A for declarations of the Indians' right to refuse to sell their lands.

${ }^{249}$ HORSMAN, supra note 90, at 86 (quoting Letter from Secretary of War Knox to Governor St. Clair (Sept. 12, 1790), reprinted in AMERICAN STATE PAPERS, supra note 81, 1 INDIAN AFFAIRS 100 (1832) (footnote omitted)).
} 
In similarly candid moments, other American officials admitted that the Indians had no free choice. James Gadsden wrote of the 1823 treaty with the Seminoles that

[i] $t$ is not necessary to disguise the fact ... that the treaty effected was in a degree a treaty of imposition-The Indians would never have voluntarily assented to the terms had they not believed that we had both the power \& disposition to compel obedience. ${ }^{250}$

United States officials often couched their threats in polite, circumspect language. Harrison, for instance, adverted to "extinguishing the council fire" instead of a more direct threat to declare war. ${ }^{251}$ When the Creeks initially refused to permit the United States to build a road through their lands, Secretary of War Eustis stated his wish that the tribe would not "compel the Government to the use of means which it is desirous to avoid." ${ }^{252}$ Furthermore, threats were not polite topics of public conversation: while charges of rape, theft, and fraud swirled among political rivals in the territorial press without evoking legal response, Harrison successfully sued William McIntosh for publicly questioning the fairness of the future President's dealings with the Indians. ${ }^{253}$ This episode, and the elliptical threats cited, show that American officials were uncomfortable with bargaining techniques that violated their own rules of voluntary exchange.

\section{c. Why the Indians Could Not Use Tricks and Threats}

The Indians had long realized that their disunity enabled the Europeans to obtain their lands cheaply via the aforementioned techniques. A founder of Plymouth Colony described with fear the prescience of one of the neighboring tribes:

[T] he Pequots, especially in the winter before [the Pequot war of 1637], sought to make peace with the Narragansetts, and used very pernicious arguments to move them thereunto: as that the English were strangers

${ }^{250}$ Letter from James Gadsen to the Secretary of War (Sept. 29, 1823), reprinted in 22 TERRITORIAL PAPERS, supra note 31, at 752 (1956).

${ }^{251}$ See supra text accompanying note 247 (discussing Harrison's veiled threat in response to an Indian tribe's attempt to gain a fair price for their land).

${ }^{252}$ HORSMAN, supra note 90 , at 163 (internal quotation omitted).

${ }^{253}$ See DAwsON, supra note 225, at 175 ("Against this [McIntosh] suit was brought by the Governor, in the supreme court of the territory, for having asserted that he had cheated the Indians, in the last treaty which had been made with them at Fort Wayne."). 
and began to overspread their country, and would deprive them thereof in time, if they were suffered to grow and increase. ${ }^{25}$

The Pequots' attempts failed to unite the tribes against the colonial advance, as did a string of other minor and major efforts, including Pontiac's Rebellion in 1763 and Tecumseh and the Prophet's movement from about 1808 to 1812 .

Why did these movements fail? Why could the Indians not unify in the face of a growing threat to their lands and their livelihoods? Why could they not employ any of the negotiating ploys that worked so well for the Americans? At the most general level, Indian society's lack of the Europeans' well-developed division of labor explains why the Indians could not mimic the negotiating ploys of their European counterparts. While Americans have perennially held legislators, executives, and bureaucrats in low esteem, it was the lack of just such a governing class that hindered Indian unity. The Indians simply could not afford to feed and clothe more than a few individuals who would hone their skills at mediating differences and administering a large, complex alliance. ${ }^{255}$

An advanced division of labor also helps to explain the Americans' advantage at the negotiating table. There is no evidence that the Indians were inherently worse bargainers than Americans. The Indians were not unable, for example, to master the art of bluffing-they simply had far fewer opportunities to practice their skills. While leading chiefs might negotiate two or three major treaties with the United States during their lifetime, men like William Henry Harrison, Andrew Jackson, Lewis Cass, and others were career treaty makers who presided over two or three treaties a year for a decade or more. ${ }^{256}$

The Americans' superior division of labor further explains why specific bargaining ploys worked for them but not for the Indians. With far more professional bureaucrats available to study the tribes, make and preserve records, and advise their superiors, the United

${ }^{254}$ WILIIAM BRADFORD, OF PIYMOUTH PLANTATION: 1620-1647, at 294 (Samuel Eliot Morison ed., 1952).

255 See JARED DIAMOND, GUNS, GERMS, AND STEEL: THE FATES OF HUMAN SOCIETIES 78-80 (1997) (attributing the Spaniards' conquest of the Incan Empire in part to Spain's "centralized political organization" and the Incan's inability to disseminate information around the Empire regarding the Europeans' hostile intentions).

${ }^{256}$ Harrison negotiated 13 treaties from 1803 to 1815 . See 7 Stats. 76, 77, 79, 82, 84, $87,92,101,115,116,117,119,132$. Jackson negotiated six from 1814 to 1820 . See 7 Stats. 122, 149, 152, 160, 194, 213. Cass treated with tribes no fewer than 22 times from 1814 to 1832 . See 7 Stats. 119, 167, 170, 180, 181, 185, 187, 189, 192, 205, 206, 207, 221, $275,292,297,302,305,306,316,319,368$. 
States undoubtedly enjoyed a tremendous informational advantage over the Indians. This made bluffing much more difficult, because the United States had a better gauge on Indian troop levels and location, stores of ammunition, alliances or feuds, and similar data crucial to negotiations. It was like a poker game where one side gets to peer into the hand of the other. Successful bluffing, in poker as in politics, requires hiding information.

"Divide and conquer" could not work for the Indians because the United States had an effective governing structure filled with officials who prevented factional feuds from erupting into permanent and serious divisions. While tribes on occasion detected disloyal leaders and punished them quite harshly, ${ }^{257}$ in general the Indians lacked effective means to deal with this agency problem. The Indians' informational disadvantage played a role here as well; American negotiators kept bribes to Indian chiefs, for the most part, secret. ${ }^{258}$ In contrast, American officials would have likely detected bribes taken by their colleagues and punished them for treason.

\section{d. The Americans' Use of Both Acceptable Tricks and Unacceptable Threats}

Great disparity between the economies of two societies does not necessarily imply that trade between the two is unfair or involuntary. Indeed, in appraising the land acquisition process described thus far, Felix Cohen found that it fit the model of voluntary exchange:

Granted that the Federal Government bought the country from the Indians, the question may still be raised whether the Indians received anything like a fair price for what they sold. The only fair answer to that question is that except in a very few cases where military duress was present the price paid for the land was one that satisfied the Indians.

No less an authority than the Supreme Court, however, has declared that Cohen's view is facile error. "Every American schoolboy knows that the savage tribes of this continent were deprived of their

${ }^{257}$ For example, when in 1824 the Creeks' anointed leaders refused to cede their Georgia lands, United States negotiators bribed a Creek faction led by William McIntosh (no known relation to the plaintiff in Johnson $v$. M'Intosh) to cede the lands instead. The tribe executed McIntosh for treason, but the signed treaty gave the United States leverage and the rightful leaders soon thereafter agreed to sell. See PrUCHA, supra note 205, at 148-51 (detailing how the United States Senate managed to remove the Creek Indians from their home territory in Georgia).

${ }^{253}$ See REMINI, supra note 207, at 330 (noting that Andrew Jackson considered keeping bribes secret to be necessary, "or the influence of the chiefs would be destroyed").

${ }^{259}$ Cohen, supra note 5 , at 38 . 
ancestral ranges by force and that, even when the Indians ceded millions of acres by treaty... it was not a sale but the conquerors' will that deprived them of their land. ${ }^{260}$

While a preponderance of the evidence presented in this Part weighs against Cohen's benign view of the voluntary nature of land sales, this Part contains limited support for Cohen's view as well. This Article proposes that this strange mix is best explained as a facet of the nation's effort to acquire Indian lands at the least possible expense. Voluntary transactions are cheaper than involuntary ones since credible threats are expensive, so the United States first tried bluffing and all the other negotiating tricks consistent with voluntary exchange. When these tactics failed, the United States moved on to threats-threats that it hoped would convince the Indians to cede land without actually fighting.

Contemporary leaders voiced precisely this view of the treatymaking process. Georgia's governor declared in 1830, in the midst of expelling the Cherokees from the state, that "treaties were expedients by which ignorant, intractable, and savage people were induced without bloodshed to yield up what civilized peoples had a right to possess by virtue of that command of the Creator delivered to man upon his formation-be fruitful, multiply, and replenish the earth, and subdue it. ${ }^{261}$ Congress expressed almost exactly the same perspective, proclaiming that paying Indians for land was "but the substitute which humanity and expediency have imposed, in place of the sword, in arriving at the actual enjoyment of property claimed by the right of discovery, and sanctioned by the natural superiority allowed to the claims of civilized communities over those of savage tribes. ${ }^{, 262}$ After canvassing the treaty-making process during the nation's first three decades, historian Reginald Horsman concurred with these assessments, noting, "[f]or white negotiators, treaty language was merely a means of obtaining land with the least conflict and expense, and a means of deflecting Indian resistance until the next, inevitable cessions were necessary." 263

The use of these bargaining tricks shows that the United States did not face a stark choice between "raid" or "trade" in obtaining Indian

${ }^{260}$ Tee-Hit-Ton Indians v. United States, 348 U.S. 272, 289-90 (1955).

261 I Francis PaUl Prucha, The Great Father: THE United States GOVERNMENT AND THE AMERICAN INDIANS 196 (1984) (citation omitted) (emphasis added).

${ }^{262} I d$. (emphasis added).

${ }^{263}$ HORSMAN, supra note 90 , at $\mathrm{x}$. 
lands-this is a false dichotomy. ${ }^{264}$ Rather, the United States pursued a middle course. It engaged in trade of $a$ sort with the Indians-trade laced with bluffs, fraud, overawing, and threats that enabled the United States to obtain land cheaply. The next Part explains why these tactics lead to more efficient expropriation than raiding (open warfare).

\section{Explaining the Rarity of Fighting: The Deadweight Loss of Fighting}

Treaty making is supposed to be simply a form of bargaining; coupled with the above testimonials to its role in least-cost acquisition of Indian lands, the process seems tailor-made for economic analysis. Yet something seems wrong with this picture: how can economics apply to the use of intimidation, threats, coercion, and warfare? Economics traditionally models voluntary exchange, with a sovereign to guard against and provide remedies for theft, fraud, breaches of contract, careless injuries, and the like. ${ }^{265}$ There was no such higher force in European-Indian relations, and, thus, for example, the Americans could get away with negotiating ploys that unquestionably would have been intolerable between two merchants in Philadelphia.

Economics can help us understand human relations even when not all dealings fit the classic model of voluntariness. This Article draws on what Jack Hirshleifer has labeled "muscular economics," or "the dark side of the force- to wit, crime, war, and politics, ${ }^{266}$ to explain Indian-white relations. While conventional economics analyzes cooperative activity (in the words of Vilfredo Pareto, "the production or transformation of economic goods, ${ }^{\text {,267 }}$ ), muscular economics deals with the

${ }^{264}$ These terms are taken from the title of Anderson \& McChesney, supra note 16, at 39 .

265 "[T] he mainline Marshallian [neoclassical economic] tradition has .... almost entirely overlooked what I will call the dark side of the force-to wit, crime, war, and politics." Jack Hirshleifer, The Dark Side of the Force, 32 ECON. INQUIRY 1, 2 (1994).

People can satisfy their desires in two main ways: by production (for self-use, or

for mutually beneficial trade with other parties), or else by conflict (i.e., by actual or threatened theft, robbery, confiscation, or litigation). Despite its evident importance, only recently has a systematic economics of struggle and conflict begun to emerge.

Jack Hirshleifer, The Technology of Conflict as an Economic Activity, 81 AM. ECON. REV. 130,130 (1991). For a wide range of articles in this vein, see THE POLIIICAL ECONOMY OF CONFLICT AND APPROPRIATION (Michelle R. Garfinkel \& Stergios Skaperdas eds., 1996).

266 Hirshleifer, supra note 265 , at 2.

${ }^{267} I d$. 
other way to obtain (if not create) wealth: expropriation of that which others possess, via "crime, war, and politics."263 Muscular economics can help us understand a host of important questions about the expropriation of Indian lands. This subsection explains a phenomenon of particular relevance to the thesis of this Article: why fighting was the exception, rather than the rule, in American-Indian relations, and why, despite a significant military advantage, the United States pursued a host of non-military strategies to obtain Indian lands cheaply. The remainder of Part II explores these non-military methods of expropriation.

While it is accepted wisdom that there was a "time-honored... practice of waging war on the Indians in order to force a land cession, ${ }^{269}$ the historical record shows that fighting was the exception rather than the rule in Indian-white relations. New England colonists waged only two wars during their first century, the era when they obtained most Indian lands in the region. Virginians, too, fought only a few small-scale wars in the process of expropriating Indian lands east of the mountains. The United States cleared the old Northwest (today, the Midwest) by fighting three battles: two crushing defeats, followed by Anthony Wayne's modest victory at Fallen Timbers in 1794. While there was a "time-honored practice" of threatening the Indians, ${ }^{270}$ rarely did these threats lead to conflict. "The claims of the historical school maintaining that Indian-white relations in this country were from start to finish determined by violence thus appear erroneous." ${ }^{271}$

This is consistent with the predictions of muscular economics. As long as potential opponents are well informed of each other's strengths, reach similar conclusions about the outcome of conflict, and can negotiate relatively easily, fighting should never occur. There are two steps to the argument underlying this assertion. First, under the assumption of full information and shared expectations, both sides know in advance the likely result of combat (which side likely will win, and how decisive a victory it likely will achieve). Second, conflict wastes all sorts of resources: human lives, labor that could have been used more productively, existing capital and productive capacity, and destroyed property. These are what economists call deadweight losses: they inure to the benefit of neither side, and are simply

\footnotetext{
${ }^{263} I d$.

${ }^{269}$ WILLLIAMS, supra note 12 , at 274.

${ }^{270}$ See supra Part II.B.2.b (exploring the use of threats in American-Indian rela-

${ }^{271}$ Anderson \& McChesney, supra note 16, at 57.
} tions). 
wasted. ${ }^{272}$ The large deadweight losses that result from warfare present combatants, in effect, with a species of gains from trade (i.e., the gains from peace). If they can strike a deal and avoid war, there will be a bigger pot of wealth and both sides can have more.

Warfare, then, is in some sense a market failure that occurs when one of the assumptions made in the previous paragraph does not hold. For instance, if one side underestimates the abilities of its opponent, it may refuse a compromise that is rational. Thus, "conflict is in large part an educational process. Struggle tends to occur when one or both of the parties is over optimistic."273 Such over-optimism may arise from a host of sources, many of which were present in AmericanIndian relations, including lack of information about the other side's strength and changing weapons technology. ${ }^{274}$ Whatever the cause of the over-optimism, the historical record shows that one or two colonial or American victories were sufficient to convince Indians in a given region that the costs of war exceeded the benefits. ${ }^{275}$ The European tactic of overawing the Indians with demonstrations of their technology, population, and military might was an attempt to educate the Indians about the futility of resistance without incurring the high

${ }^{272}$ For a definition and illustration of deadweight loss, see WALTER NICHOLSON, MICROECONOMIC THEORY: BASIC PRINCIPLES AND EXTENSIONS 429-30 (3d ed. 1985).

${ }^{273}$ Jack Hirshleifer, The Economic Approach to Conflich, in ECONOMIC IMPERIALISM: THE ECONOMIC METHOD APPLIED OUTSIDE THE FIELD OF ECONOMICS 335, 340 (Gerard Radnitzky \& Peter Bernholz eds., 1987).

${ }^{274}$ See Anderson \& McChesney, supra note 16, at 48-50, 53 (noting the effects of "information assymetry").

${ }^{275}$ See infra notes 281-84 and accompanying text (discussing how successful wars against Indians in New England ended the tribes' resistance to colonizers). Another "market failure" that may have led to conflict between Europeans and Indians was the difficulty of negotiation. For example, certain tribes had no clear leaders, or had leaders who could not hold their warriors to the bargains they entered, making effective negotiation problematic. See Anderson \& McChesney, supra note 16, at 62-63 (detailing the difficulty Europeans had negotiating land treaties with the nomadic and politically unstructured Western Indian tribes).

Beyond such market failures, basic characteristics of societies also determine whether they can reach peaceful accommodation or will square off in battle. For instance, cooperation is more likely when production between the two sides is complementary and they can produce more wealth by combining their talents than they could if they remained isolated. See Hirshleifer, supra note 265, at 4 (citing Solomon William Polachek, Conflict and Trade, 24 J. CONFLICT RESOL. 55 (1980)) (noting that "nations that trade more fight less")). This may explain, for example, why the French had more peaceful relations with the Indians than the British. The primary economic activity of the French was fur trading, and the Indians, as by far the more skilled trappers, were a key part of this industry. The British, on the other hand, engaged in fairly large-scale agriculture, a use inconsistent with the Indians' heavy reliance on hunting and gathering in uncleared forests. 
deadweight costs of warfare. ${ }^{276}$

This in no way implies that the relative strengths of the parties do not matter-strength determines likely losses from battle in terms of all the costs of warfare discussed above (life, productive labor, etc.), and gains from expropriating the land or other contested assets. When the two sides then sit down at the negotiating table, neither will accept less than they could achieve by fighting. Thus, the predicted outcome of conflict sets a floor as to what each side will accept in compromise; these floors set the rough terms of trade within which bargains will fall. ${ }^{277}$ Given that conflict entails inevitable waste, there is room for both sides to compromise and walk away with more than these floors. This room for compromise is simply the gains from trade discussed above.

John Umbeck presented powerful support for this model of muscular economics in a study of the rules developed by miners to assign claims during the California gold rush. ${ }^{278}$ Despite the presence of thousands of armed miners in remote areas, bereft of any official authority, violence with its attendant deadweight losses was extraordinarily rare. ${ }^{279}$ Moreover, given the fact that guns equalized everyone's ability to use force, Umbeck expected to find, and did find, that the miners' legal rules allocated roughly equal-valued tracts to all comers. $^{280}$

Such equality prevailed during the early era of European contact with the Indians. In the first decades of the New England settlements, "the Indians were not weak, dependent groups of people that needed protection but powerful equals whom the early settlers had to deal with as independent nations." ${ }^{, 21}$ Under these conditions, the colonists

${ }^{276}$ See supra Part II.B.2 (discussing the bargaining game between Americans and Indians and the tactics Americans used to prevent fighting).

${ }^{277}$ See Anderson \& McChesney, supra note 16, at 46 (using phrase "terms of trade" in this context of two opposing sides considering warfare to resolve a dispute).

${ }^{278}$ See John Umbeck, Might Makes Rights: A Theory of the Formation and Initial Distribution of Property Rights, 19 ECON. INQUIRY 38 (1981) (explaining how threat of force influenced the allocation of property rights among miners in the California gold rush). See generally JOHN R. UMBECK, A THEORY OF PROPERTY RIGHTS: WITH APPLICATION TO THE CALIFORNIA GOLD RUSH 50 (1981) (describing the origin and development of private property rights and using the California gold rush as a paradigmatic illustration).

${ }^{279}$ See Umbeck, supra note 278, at 49-50 ("Most of the miners carried guns, yet the reports of violence during the early period are remarkably scarce.").

${ }^{280}$ See id. at 54-56 ("[T] he land within [certain] districts appears to have been roughly homogeneous with respect to [many] characteristics....").

KAWASHIMA, supra note 33, at 3. 
could not intimidate the tribes, (for example, into selling land below a voluntarily determined price). This parity disappeared after a few successful wars against the tribes. ${ }^{282}$

A similar story played out in the Great Lakes tribes' successive relationships with the French, British, and Americans. In a rich, detailed panorama, Richard White demonstrates how rough military parity forced the tribes and the early waves of colonizers to seek a "middle ground" and accommodate each other. "The middle ground depended on the inability of both sides to gain their ends through force. The middle ground grew according to the need of people to find a means, other than force, to gain the cooperation or consent of foreigners. ${ }^{283}$ This delicate balance could not survive America's growing might. "The real crisis and the final dissolution of this world came when Indians ceased to have the power to force whites onto the middle ground. Then the desire of whites to dictate the terms of accommodation could be given its head. ${ }^{284}$

Despite the colonists' growing military advantages, it is important to emphasize that the Indians remained formidable adversaries capable of inflicting serious harm, economically as well as in terms of life and limb. ${ }^{285}$ While growing European might continually moved the muscular economic terms of trade in America's favor, the cost of fighting the Indians never became anything near trivial. Colonial and American leaders were well aware of the high expense of Indian wars and avoided them assiduously. ${ }^{286}$ American threats to fight rather than negotiate were thus generally not credible.

The Indians' strength during the first century of contact was manifest; they repeatedly turned back Spanish incursions in Florida despite the conquistadors' "supposed advantages of steel swords, crossbows, muskets, armor, horses, war dogs, and a crusading warrior mentality. ${ }^{287}$ Even after colonists built towns, learned to feed them-

282 See STEELE, supra note 204, at 80-110 (documenting that King Philip's War effectively ended New England tribes' resistance to colonizers).

283 WHITE, supra note 62, at 52.

284 Id. at xv.

${ }^{285}$ There is perhaps no better example of the continuing seriousness of the Indian threat, despite American might, than the massacre of Custer and his men at Little Big Horn in 1876. The Sioux decimated an elite, battle-hardened calvary unit.

${ }^{286}$ While the polity's concern for the lives of (non-voting, non-wealthy, noninfluential) frontier settlers may seem doubtful, it is important to remember that the greatest source of national wealth for the United States was its extensive western lands. To realize the lands' value, the nation needed to attract settlers; the more dangerous the frontier, the more difficult (i.e., expensive) it would be to lure them.

${ }^{287}$ STEELE, supra note 204 , at 19 . Florida "had proved to be nothing but a drain on 
selves, and established organized governments with militias, Indian wars threatened their very existence. Over half of Plymouth Colony's towns were destroyed or damaged in King Philip's War in 1676, and one in twelve of Plymouth's adult males died in the fighting. ${ }^{285}$

White incursions continued, yet the Indians were not yet cowed by European might. During Pontiac's Uprising, a disorganized, spontaneous set of attacks in 1763, the Great Lakes Indians killed no less than 2000 whites, in addition to taking most forts in the region and besieging the large installation at Fort Pitt. ${ }^{299}$ "Small triumphs came at the risk of ambush and catastrophic defeat... [and the] cost of waging the Indian wars [was high]. ${ }^{290}$ In short, Indian wars were expensive, risky, and unrewarding even in victory.

American leaders were well aware of the sizeable costs of Indian wars. Chief Justice Marshall, in a rough cost-benefit analysis, declared the tribes "too powerful and brave not to be dreaded as formidable enemies, requir [ing] that means should be adopted for the preservation of peace." ${ }^{291}$ Only months after the nation won its independence, Washington advised Congress that:

[P]olicy and economy point very strongly to the expediency of being upon good terms with the Indians, and the propriety of purchasing their Lands in preference to attempting to drive them by force of arms out of their Country.... [T] here is nothing to be obtained by an Indian War but the Soil they live on and this can be had by purchase at less expense, and without ... bloodshed .... ${ }^{292}$

the resources of Spain." John J. TePaske, Spanish Indian Policy $\mathcal{E}$ the Struggle for Empire in the Sontheast, 1513-1776, at 25, 27, in CONTEST FOR EMPIRE 1500-1775 (John B. Elliot ed., 1975). The Spanish had more success with peaceful settlements centered around religious missions. See id. at 30.

${ }_{283}$ See STEELE, supra note 204, at 107-08 (describing King Philip's War). Other costs were equally high: "eight thousand head of Cattle great and small, killed, and many thousand bushels of wheat, pease, and other grain burnt." JENNINGS, supra note 10 , at 324.

${ }^{289}$ See SOSIN, supra note 225 , at $6-7$ (describing Indian attacks prompted by Pontiac's Uprising and claiming that "[m]ore than 2000 [frontier settlers] were killed"); STEELE, supra note 204, at 241 ("An estimated two thousand American traders and settlers were killed or taken captive [by supporters of Pontiac].").

${ }^{290}$ WHITE, supra note 62, at 290.

291 Johnson v. M'Intosh, 21 U.S. (8 Wheat.) 543, 596-97 (1823).

292 Letter from George Washington, President of the United States, to James Duane, Chairman of the Committee of Congress to Confer with the Commander in Chief (Sept. 7, 1783), in 27 THE WRIIINGS OF GEORGE WASHINGION 133, 140 (John C. Fitzpatrick ed., 1938) [hereinafter WRITINGS OF WASHINGTON]. 
Washington repeated this caution about the expense of Indian wars in subsequent State of the Union addresses. ${ }^{293}$ Other leaders agreed. In 1790, Secretary of War Knox counseled Congress that "[a] comparative view of the expenses of a hostile or conciliatory system towards the Indians will evince the infinite economy of the latter over the former. ${ }^{204}$ He urged Congress against asserting any right of conquest over the Indians because of the Indians' alliance with the defeated British. "To establish claims by the principle of conquest would mean continuous warfare. ${ }^{295}$ Realists in Congress concurred and "recommended some compensation for Indian claims rather than risk another Indian war and the tremendous expense it would bring." Pelatiah Webster summed up the common wisdom: "[N]obody ever yet gained any thing by an Indian war. Their spoils are of no value; but their revenge and depredations are terrible. It is much cheaper to purchase their lands, than to dispossess them by force. . . ."2997

Consciously paying for Indian lands to avoid costly warfare undermines benevolent interpretations of American policy, yet scholars continue to defend the morality of the nation's land purchases. For example, Cohen argues that while "it was only natural that the first settlers ... who were for many decades outnumbered by the Indians ... should have adopted the prudent procedure of buying lands," the nation's continued willingness to buy, instead of grab, Indian lands evidenced high moral character.

What is significant ... is that at the end of the 18th Century when our population east of the Mississippi was at least 20 times as great as the Indian population in the same region and when our army of Revolutionary veterans might have been used to break down Indian claims to land ownership and reduce the Indians to serfdom or landlessness, we took

${ }^{299}$ See George Washington, Fourth Annual Message (Nov. 6, 1792), in GEORGE WASHINGTON: A COLIECTION 480-81 (W.B. Allen ed., 1988) ("An earnest desire ... to arrest the progress of expense ... has led to strenuous efforts . . . .); Sixth Annual Message (Nov. 19, 1794), in WASHINGION, supra, at 492, 497 (commenting on the "extraordinary expense and waste" of the militia); Seventh Annual Message (Dec. 8, 1795), in WASHINGTON, supra, at 499, 500 (commenting on the "further expense" of continuing conflict with the Indians).

${ }^{294}$ Report of Secretary of War Knox to Congress (Jan. 4, 1790), reprinted in AMERICAN STATE PAPERS, supra note 81, 1 INDIAN AFFAIRS 59-61 (1832).

295 PRUCHA, supra note 261, at 49.

296 Id. at 43.

297 PELATIAF WEBSTER, POLITICAL ESSAYS ON THE NATURE AND OPERATION OF MONEY, PUBLIC FINANCES, AND OTHER SUBJECTS 495 (1791). 
seriously our national proclamation that all men are created equal and undertook to respect [Indian] property rights .... ${ }^{298}$

The historical record, however, indicates that it would have been quite expensive to physically oust the Indians. ${ }^{299}$

The economic analysis of this Part complements history in undermining the view that the United States pursued a conscious war of annihilation against the Indians. M'Intosh itself, granting the Indians limited rights and refusing to root titles in unjust wars, is inconsistent with genocidal policy. Simply put, exterminating the Indians with direct violence would have been quite costly, and yet would have yielded few if any benefits beyond those obtained from the policy of expropriating Indian lands as cheaply as possible.

The historical data support this Article's thesis that least-cost conquest explains most colonial and American laws and policies for dealing with the Indians. When Marshall declined to authorize offensive wars of conquest in M'Intosh, he simply made the law congruent with the practicalities of dealing with the tribes. Simply put, outright conquest and annihilation were not efficient ways of expropriating Indian lands. Like any prudent cost minimizer, the United States considered the whole range of methods to obtain Indian lands cheaply. Hirshleifer makes this point colorfully. He labels productive (cooperative, mutually voluntary exchange) activity "the way of Coase," expropriative activity (coerced, involuntary exchange) "the way of Machiavelli," ${ }^{301}$ and posits that "decision-makers will strike an optimal balance between the way of Coase and the way of Machiavelli-between the production combined with mutually advantageous exchange, and the dark-side way of confiscation, exploitation, and conflict." ${ }^{302}$ American officials did not face a binary choice between "raid or trade"-Machiavelli or Coase-but rather a continuum of strategies incorporating techniques from both approaches to maximizing benefits and minimizing costs.

${ }^{298}$ Cohen, supra note 5, at $40-41$.

${ }^{299}$ See HORSMAN, supra note 90, at 86-89 (describing expeditions led by generals Harmar (1790) and St. Clair (1791) that suffered crushing defeats at the hands of the northern tribes).

${ }^{500}$ In honor of Ronald Coase, most famous for arguing that, as long as it is relatively easy to bargain, parties will choose least-cost methods to deal with inconsistent activities. See generally R.H. Coase, The Problem of Social Cost, 3 J.L. \& EcON. 1 (1960).

${ }^{301}$ In honor of Niccolo Machiavelli, prominent student of political intrigue. See generally NICCOLO MACHIAVELII, THE PRINCE (Angelo M. Codevilla trans. \& ed., 1997) (outlining pragmatic and ruthless avenues to power).

${ }^{302}$ Hirshleifer, supra note 265 , at 3. 
Conflict (Machiavelli) took the United States only so far. The Indians' ability to inflict significant losses in warfare meant that despite the inevitability of European victory, threats to take Indian land by force were not entirely credible. The United States, though starting from a position of strength, was still locked in a bargaining game with the Indians to divide the surplus that arose from a peaceful (Coasean) transfer of lands. Even with the favorable terms of trade based on superior might, the Indians remained formidable foes. There was, then, lots of room between the minima each side would accept, based on avoiding the deadweight loss of actually fighting. To illustrate this concept, and the remainder of this Part, consider the following simplified version of the negotiating game between the United States and the Indians:

- if the two sides can avoid conflict, the gains from trade are ten;

- each side has two negotiating stances: tough or conciliatory;

- if both sides negotiate in a tough manner, conflict results; the United States wins but pays a high price, while the Indians lose in addition to paying a high price;

- if even one side is conciliatory, the parties reach a compromise;

- a party acting tough in negotiations, while the opposition is conciliatory, obtains a larger share of the gains from trade.

The following table encapsulates the choices facing the parties under these assumptions:

\begin{tabular}{|c|c|c|c|}
\hline & \multicolumn{2}{|c|}{ Indians } \\
\hline & & Tough & Conciliatory \\
\hline \multirow{2}{*}{ 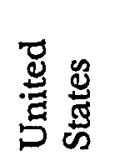 } & Tough & 2,0 & 9,1 \\
\hline & Conciliatory & 3,7 & 5,5 \\
\hline
\end{tabular}

(payoffs: U.S., Indians)

Figure 2

Note that fighting occurs only when both sides take a tough negotiating stance, and if fighting occurs the deadweight losses consume eighty percent of the gains from trade. In the other three cases, the 
parties will realize all the gains from trade; the only question is how the parties will divide the spoils. The lower left and upper right entries (one side tough, the other conciliatory) reflect the assumption that even when conciliatory, neither side will take less in negotiations than it will receive in the event of fighting. These two outcomes, the minimal amount acceptable to each side, set the terms of trade between the parties in this model of muscular economics. The lower right payoffs (both sides conciliatory) must fall somewhere between the lower left and the upper right.

As a first cut at solving this game, there are two strategy combinations that are stable: the lower left and the upper right. ${ }^{303}$ If one side could somehow convince the other that they intended to stick to a tough bargaining stance, the other side's rational response is conciliation (to avoid a costly war). The problem is forming a credible commitment to such a strategy; each side knows that threats to engage in warfare are irrational as long as a proffered compromise leaves the threatening party with more than it receives after combat (two for the United States; zero for the Indians). Thus $(3,7)$ and $(9,1)$ are plausible outcomes of this game, as is any pair in-between, for example $(4,6),(5,5),(6,4)$, and so on.

This wide range of possible outcomes is the defining characteristic of the negotiating games discussed above and explains why, despite an overwhelming military advantage, it was still worthwhile for the United States to engage in all sorts of negotiating ploys to maximize its share of the "gains from trade" while avoiding the waste of conflict. Bluffing, "divide and conquer," and other ploys enabled the United States to negotiate an outcome much closer to $(9,1)$ than to $(3,7)$. In addition to its bargaining advantages, the United States also had the ability to effectively change the numbers in this game by spreading disease among the Indians and thinning the game on which they relied. The following Part explores these potent additions to the techniques used by the United States to obtain Indian lands cheaply.

${ }^{303}$ For both of these strategy combinations, neither party has incentives to change its "move." Game theorists call such stable strategy combinations "Nash equilibria." See ROBERT GIBBONS, GAME THEORY FOR APPLIED ECONOMISTS 8-9 (1992) (describing Nash equilibria and explaining that each party's "predicted strategy must be that [party's] best response to the predicted strategies of the other [parties]"-thus, imperfect information about the other party discourages each party from choosing its predicted move). 


\section{Altering the Terms of Trade: Natural Allies}

The Europeans' most powerful methods of altering the basic terms of trade did not involve human action-warlike or otherwisebut rather other life forms small and large brought across the ocean. Microbes decimated Indian populations, reducing if not eliminating their ability to defend their lands. European crops and domestic animals displaced the forests and game animals that constituted an important part of the Indians' food supply, rendering lands in the neighborhood of settlement of little value to the tribes. This Part details the workings of disease and game-thinning; Part II.E shows how legal rules maximized the effect of these natural allies by encouraging and channeling settlement, and minimized potentially costly sideeffects the settlers might cause for their neighbors and the nation. This Part will also try to determine whether legal rules that enhanced these natural allies are best classified as Coasean, as Machiavellian, or, like some of the negotiating ploys discussed above in Part II.B.2, as falling in a gray area between the two.

\section{Depopulation by Disease}

The pre-contact Indian population of North America was anywhere from one to eighteen million. ${ }^{304}$ Nowhere near even one hundred thousand Indians died as the direct result of European violence. ${ }^{305}$ Even accepting lowest estimates and assuming that the Indian population plateaued, the obvious question is, what killed all the Indians?

Beyond peradventure, the answer is microbes. "The most potent

${ }^{304}$ "Current United States history textbooks illustrate just how far from settled [the issue of Indian population] is: their estimates of aboriginal population in 1492 vary from one to twelve million." John D. Daniels, The Indian Population of North America in 1492, 49 WM. \& MARY Q. 298, 298 (1992); see also id. at 315 (citing Henry F. Dobyns's estimate of aboriginal Indian populations circa 1492). Daniels cites estimates of up to eighteen million, apparently not mentioned in the textbooks. Daniels's article, a careful canvas of the literature, catalogs no less than 11 methods of estimating the early Indian populations, from pure guesstimates, to count multiples (for example, taking European reports on the number of warriors and multiplying by three to derive Indian population), to determining carrying capacity (that is, assume population expanded to use all food sources present and exploitable with the Indians' technology). See id. at 304-09 (describing the 11 methods within three broad groupings). Given the paucity of data, more precise estimates appear impossible.

${ }^{305}$ See Russell, supra note 7, at 46-47 (estimating a total of 5172 Indian deaths due to European violence-1172 from "massacres," 3000 from fights with the U.S. Army, and 1000 from killings by civilians). 
weapon in the invasion of North America was not the gun, the horse, the Bible, or European 'civilization.' It was pestilence, feared by all and understood by none, that carried off untold tens of thousands ... "306 "Of all the many organisms Europeans carried to America [including themselves], none of them were more devastating to the Indians than the Old World diseases ...." ${ }^{307}$ Smallpox and other eruptive fevers were weapons "more effective, of greater range, of surer aim than any rifle or poison gas ever devised."

In Europe, large numbers of domesticated animals relatively similar to humans (such as cows and pigs) created an environment in which a host of microbes jumped the species barrier, mutated, and became endemic. ${ }^{309}$ While such diseases may have been initially devastating, centuries of natural selection during which only those who survived, evidencing some resistance, produced offspring continuously reduced the mortality rate among Europeans. Diseases such as smallpox and measles reached an endemic equilibrium in Europe: large populations created a continuous flow of children hosts for these microbes. Most of these children survived and were likely to produce their own children who could also weather the diseases.

American Indians did not domesticate any animals except for dogs, and hence did not accumulate any such microbes. Their relatively sparse populations did not contain a large enough supply of fresh, nonresistant children to maintain endemic diseases. The implications of this asymmetry were enormous. The Indians were immunologically defenseless against European endemic diseases. ${ }^{311}$ Unlike the Europeans, Indians at the time of contact had not benefited from generations of natural selection-based resistance to the diseases; therefore, the microbes routinely decimated Indian villages in weeks. ${ }^{312}$

${ }^{306}$ STEELE, supra note 204, at 22.

${ }^{307}$ WILLIAM CRONON, CHANGES IN THE LAND: INDIANS, COLONISTS, AND THE ECOLOGY OF NEW ENGLAND 85 (1983).

${ }^{308}$ COLONEL P.M. ASHBURN, THE RANKS OF DEATH: A MEdICAL HISTORY OF THE CONQUEST OF AMERICA 81 (Frank D. Ashburn ed., 1947).

${ }^{309}$ DIAMOND, supra note 255, at 195-214 (describing the link between livestock and disease).

${ }^{310}$ See generally id. at 201 ("[H]uman populations repeatedly exposed to a particular pathogen have come to consist of a higher proportion of individuals with those genes for resistance-just because unfortunate individuals without the genes were less likely to survive to pass their genes on to babies.").

${ }^{311}$ See id. at 202-11 (discussing the spread of diseases and the effect of European diseases on Indians).

${ }^{312}$ For the same reason that they lacked defenses against European microbes (lack 
European colonists carried deadly microbes wherever they went. Virginia colonists noticed epidemics as early as 1585 , and by 1608 , a Jamestown settler reported a "strange mortalitie" affecting "a great part of the [Indians]" in the Chesapeake Bay area. ${ }^{313}$ Smallpox may have reached New England before the first permanent settlements; ${ }^{314}$ at any rate, within ten years of the Pilgrims' arrival in 1617, devastating epidemics struck. "Mortality rates in initial onslaughts were rarely less than eighty or ninety percent, and it was not unheard of for an entire village to be wiped out... A long process of depopulation set in, accompanied by massive social and economic disorganization. . $^{315}$

of large domestic animals, sparse population), Indians did not have the "offense" of their own set of endemic microbes to infect Europeans. The only microbe that may have originated in the New World and become epidemic among Europeans was syphilis. See ARNO KarLen, MAN \& MICROBES: DISEASE AND PLAGUES IN HistoRY AND MODERN TIMES 121-28 (1995) (describing the possibility that syphilis arose in the New World).

This is not to say that the Europeans faced no microbial barriers to settlement. Malaria, for instance, was common along the Mississippi River in southern Illinois, adjoining the Illinois Company's southern tract, and this impeded settlement until swamps were drained. See 1 CLARENCE WALWORTH ALVORD, THE MISSISSIPPI VALIEY IN BRITISH POLITICS: A STUDY OF THE TRADE, LAND SPECULATION, AND EXPERIMENTS IN IMPERIALISM GULMINATING IN THE AMERICAN REVOLUTION 416 (1959) (noting that the prevalence of malaria had made Illinois an unhealthful place to live); AIBERT T. VOLWIIER, GEORGE CROGHAN AND THE WESTWARD MOVEMENT, 1741-1782, at 198 (1926) (describing malaria as the "curse of Illinois"). William Murray, a field agent of the United Companies, contracted the disease. See Marks, supra note 50, at 196 (noting that William Murray, a trader and land speculator in Illinois, was stricken with malaria fever). Infection and mortality rates for malaria, however, were minuscule compared to those for smallpox and other endemic European diseases.

${ }_{914}^{315}$ JENNINGS, supra note 10 , at 23.

914 According to one original settler, Massachusetts colonists found large tracts of land deserted, reportedly due to a "great mortality, which fell in all these parts about three years before the coming of the English, wherein thousands of [Indians] died." BRADFORD, supra note 254 , at 87.

There is a heated debate among current scholars, however, about exactly when European diseases reached the New England tribes. See Dean R. Snow \& Kim M. Lanphear, European Contact and Indian Depopulation in the Northeasl: The Timing of the First Epidemics, 35 ETHNOHIST. 15, 17-24 (1988) (arguing that epidemics did not strike the Northeast until the seventeenth century); see also Dean R. Snow \& William A. Starna, Sixteenth-Century Depopulation: A View from the Molawk Valley, 91 AM. ANTHROPOLOGIST 142 (1989) (reaffirming that epidemics did not strike until after 1600).

${ }^{315}$ CRONON, supra note 307 , at 86 . Cronon estimates that the Indian population of New England fell from 70,000 in 1600 to less than 12,000 by 1675 . "In some areas, the decline was even more dramatic: New Hampshire and Vermont were virtually depopulated as the western Abenaki declined from perhaps 10,000 to fewer than 500." Id. at 89. For a detailed history of the spread of smallpox and other epidemic diseases among Indians, see JOHN DUFF, EPIDEMICS IN COLONLAI AMERICA 244 (1953) (discussing the impact of smallpox on the Indians during the colonial period); ANN $F$. RAMENOFSKY, VECTORS OF DEATH 171 (1987) (describing a study concluding that dis- 
After these initial devastating epidemics, the surviving Indians were immune. Their children, however, were not always so lucky. While being the product of one generation of natural selection for immunity to the disease raised their odds of survival slightly, they remained much more vulnerable than their European counterparts. ${ }^{316}$ Thus, in the early 1630s, about a generation after the epidemics of 1617 , another outbreak decimated the Massachusetts Indians. ${ }^{317}$ Whether infecting tribes for the first time or striking later generations, microbes marched west in lock step with settlers. Smallpox ravaged the Pequot of Connecticut in $1633^{318}$ soon after the British established a trading post nearby; it hit the easternmost tribe of the Five Nations-the Mohawk- a few years later, ${ }^{319}$ and reached the westernmost members of that confederation-the Seneca-by the 1660 s. $^{320}$ During the 1690 s, epidemics similarly marched west on the southern frontier. $^{321}$ As mentioned earlier in Part I.B, these epidemics reached the Illinois region around 1680 and decimated the tribes from whom the Illinois and Wabash Companies purchased their lands. Future generations of the Illinois and Wabash tribes remained susceptible to epidemics; in 1793, negotiations with the Wabash tribes had to be canceled "because many of the principal Wabash chiefs had died of

ease was "the most important single factor in the demographic catastrophe of Native Americans"); and E. WAGNER STEARN \& ALIEN E. STEARN, THE EFFECT OF SMALIPOX ON THE DESTINY OF THE AMERINDIAN 13 (1945) (describing the disastrous impact the arrival of smallpox had on the Indian population).

${ }^{316}$ See HENRY F. DOBYNS, THEIR NUMBER BECOME THINNED 14 (1983).

317 The colonists interpreted the epidemics' much greater impact on the Indians as divine intervention. "About [1631] the Indians began to be quarrelsome about [colonists' encroachments], but God ended the Controversy by sending the Small-pox amongst the Indians. ... Whole Towns of them were swept away, in some of them not so much as one Soul escaping the Destruction." INCREASE MATHER, EARLYHISTORY OF NEW ENGLAND 110 (1864 ed. private printing) (1677); see also BRADFORD, supra note 254, at 271 ("The chief sachem himself now died and almost all his friends and kindred. But by the marvelous goodness and providence of God, not one of the English was so much as sick or in the least measure tainted with this disease ....").

${ }^{318}$ See STEELE, supra note 204, at 89 ("The Pequot, thought to have numbered some thirteen thousand, were reduced to a mere three thousand.").

${ }^{319}$ See id. at 115 ("The Mohawk were suddenly devastated by the massive smallpox epidemic that struck all the Five Nations and the New England Algonquions in 1633 .... Of a population of some eighty-one hundred, only two thousand Mohawk survived this initial epidemic.").

${ }^{320}$ See id. at 117 ("Being farther inland, [the Seneca] had suffered less than the Mohawk in the [small pox] epidemics of the 1630s, though they would be harder hit in the 1660s.").

${ }^{521}$ See id. at 153 ("[C]ontact with the English brought epidemic disease; the Creek [a southern Indian confederacy] population fell by 40 percent to nine thousand during the 1690s."). 
smallpox." ${ }^{322}$

While Europeans practiced the ancient art of inoculation and developed a smallpox vaccine in $1796,{ }^{323}$ they possessed limited knowledge of infectious diseases. It is improbable that they attempted to employ biological warfare and almost certain that such efforts would have failed. In a widely-cited letter, British General Amherst asked a subordinate whether it "[c]ould ... be contrived to send the Small Pox among those disaffected tribes of Indians," and proposed spreading smallpox via blankets planted with pustules from soldiers with the disease. ${ }^{324}$ No historical evidence indicates that the British attempted this, ${ }^{325}$ and while possible, it is very difficult for smallpox residing in blankets to spread.

Although the Europeans could not control their microbial allies, the Indians, suffering again from radically imperfect information, may have thought otherwise. Squanto, a New England Indian who cooperated with the settlers, convinced his fellow Indians that the colonists "kept the plague buried in the ground, and could send it amongst whom they would, which did much terrify the Indians., ${ }^{326}$ The Wabash tribes in 1800 worried "that the United States intended to destroy them by means of the small pox, which was to be communicated to them by the goods which they received from [the Europeans]. ${ }^{3227}$ Thus even though disease was a serendipitous ally, Indian overestimation of European power to employ disease as a weapon may have tilted the already favorable terms of trade even further in the colonists' favor.

A different kind of disease played a similar role in weakening tribal resistance to bargain-basement offers for their lands: alcoholism. Just as they had no genetic defenses against smallpox, so too Indians had never been exposed to fermented beverages and were

322 PRUCHA, supra note 205, at 91.

${ }^{323}$ Inoculation, practiced around the world for centuries, involves inserting infectious material underneath the skin; for some diseases this results in a weak case of the illness, thereby conferring immunity. See DUFF, supra note 315 , at 24 . Edward Jenner derived the first vaccination, for smallpox, in 1796. See id. at 26-42.

3242 FRANCIS PARKMAN, CONSPIRACY OF PONTIAC AND THE INDIAN WAR AFTER THE CONQUEST OF CANADA 44 (1929).

${ }^{325}$ See Bernhard Knollenberg, General Amherst and Germ Warfare, 41 MISs. VALIEY HIST, REv. 489, 494 (1954) (rejecting earlier historical analyses and concluding that while Amherst and others may have had the intent to spread smallpox, "execution of the intent is not supported even by circumstantial evidence").

${ }_{926}$ BRADFORD, supra note 254, at 99.

927 DAwsON, supra note 225, at 14-15 (quoting Letter from Major-General William Henry Harrison, to Secretary of War Henry Dearborn (Feb. 19, 1802)). 
equally defenseless to alcohol addiction.

Alcohol held a special place in the history of tribal disintegration.... Without the startling finality of smallpox, it set in train the process of lingering devastation that not only wore on the physical health of the natives but attacked the very coherence of their social order. In epidemic force it ravaged tribe after tribe until the drunken, reprobate Indian became a fixture in American folklore. ${ }^{328}$

While the colonies and later the nation passed numerous laws to regulate or ban the liquor trade, these proved no more effective than the laws that attempted to regulate the sale of weapons to the tribes. The Europeans never devoted significant resources to stemming the flow of liquor to the Indians, and they continually worried about the adverse economic consequences of barring trade of a good in such high demand. ${ }^{329}$

\section{Game-Thinning}

Even with the advantages of Indian alcoholism, vulnerability to disease, and inferior military technology, the Spanish, as noted by de Tocqueville, were "unable to exterminate the Indian race by those unparalleled atrocities which brand them with indelible shame, nor did they succeed even in wholly depriving it of its rights. ${ }^{\text {,330 }}$ The Americans, despite resorting less often to atrocities, did manage to deprive the Indians of their rights, virtually exterminating them. The difference between the two colonial methods was simple: the Americans engaged in widespread agricultural settlement; the Spanish generally did not. As a result, "[s]ettlers, who ultimately would prove to be the most effective conquerors of North America, were by far the weakest of the ... elements" in Spain's invasion of the New World. ${ }^{331}$

Chief Justice Marshall adverted to the most important harmful effect of such settlement in the M'Intosh opinion itself: "As the white population advanced, that of the Indians necessarily receded. The country in the immediate neighborhood of agriculturists became unfit for them. The game fled into thicker and more unbroken forests, and the Indians followed." ${ }^{392}$ Although many eastern tribes engaged in

${ }^{328}$ BERNARD W. SHEEHAN, SEEDS OF EXTINCTION: JEFFERSONIAN PHILANTHROPY AND THE AMERICAN INDIAN 232 (1973).

${ }^{329}$ See PRUCHA, supra note 6, at 102-38 (describing the often ineffective attempts to control the trade of whiskey to the Indians).

${ }^{350}$ DE TOCQUEVILLE, supra note 1 and accompanying text.

331 STEELE, supra note 204, at 29-30.

${ }^{352}$ Johnson v. M'Intosh, 21 U.S. (8 Wheat.) 543, 590-91 (1823). 
small-scale agriculture, raising corn, beans, and squash, they still depended on the hunt for a significant portion of their diet (as well as for clothing, tools, and other essentials). Chancellor Kent, writing only a decade after the opinion, presciently forecast the result of the settlers' systematic clearing of Indian game habitats: "[T] he Indians of this continent appear to be destined, at no very distant period of time, to disappear with those vast forests which once covered the country, and the existence of which seems essential to their own." 333

Agriculture and husbandry reduced wild animal populations in three ways. First and foremost, clearing land for planting reduced forested habitat acre for acre. Second, Europeans themselves hunted game at a prodigious rate, often only for skins. ${ }^{334}$ Third, European domestic livestock, the product of natural selection in crowded environments, successfully competed against the wild animals of the New World. ${ }^{335}$ Cronon summed up these effects on the once abundant deer population of New England: "Deer were threatened by changes in their habitat, augmented numbers of hunters, and competition from domestic livestock. ${ }^{336}$

The effect on game in New England was rapid and severe. "Massachusetts enforced its first closed season on [deer] hunting in 1694, and in 1718 all hunting of them was forbidden for a closed term of three years. By the 1740 s, a series of 'deer reeves'-early game war-

33s KENT'S COMMENTARIES, supra note 46 , at *400.

934 In 1801, William Henry Harrison noted that Kentuckians crossed the Ohio every fall to hunt deer, bear, and buffalo in the Indiana Territory (still Indian land at the time). "One white hunter will destroy more game than five of the common Indians-the latter generally contenting himself with a sufficiency for present subsistance-while the other eager after game hunt for the skin of the animal alone." Letter from William Henry Harrison, Governor of the Indiana Territory, to Henry Dearborn, Secretary of War (July 15, 1801), in MESSAGES \& LETTERS OF WILLIAM HENRY HARRISON, supra note 82, at 27. "The Shawnee complained in 1802 that 'at present they kill more than we do[.] They would be angry if we were to kill a cow or a hog of theirs, the little game that remains is very dear to us." SHEEHAN, supra note 328, at 222.

Contributing to the destruction of game stocks, Indians began to kill greater numbers of deer and other large herbivores and take only their valuable hides. "They no longer killed primarily for sustenance.... [T] his new prodigality left the forest strewn with skinned carcasses fed upon by packs of wolves." Id.

395 "Old World livestock, which had evolved in what seemingly had been a rougher league than that of the New World, often outfought, outran, or at least outreproduced American predators." AIFRED W. CROSBY, GERMS, SEEDS \& ANIMALS: STUDIES IN ECOLOGICAL HISTORY 10 (1994). "[T]he advancing European frontier from New England to the Gulf of Mexico was preceded into Indian territory by an avant-garde of semiwild herds of hogs and cattle...." Id. at 33.

${ }^{936}$ CRONON, supra note 307 , at 101 . 
dens-were regulating the deer hunt, but to little avail.".337 By 1672, wild turkey and other game birds were virtually extinct. ${ }^{338}$ Local tribes felt the squeeze less than forty years after the Pilgrims arrived.

[O]ur fathers had plenty of deer and skins, our plains were full of deer, as also our woods, and of turkies, and our coves full of fish and fowl. But these English having gotten our land, they with scythes cut down the grass, and with axes fell the trees; their cows and horses eat the grass, and their hogs spoil our clam banks, and we shall all be starved.

In a little over a century and a half, the process was complete. The Mohegan Indians, in a 1789 petition for charity from the Connecticut legislature, lamented that "in Times past, our Fore-Fathers lived in Peace, Love, and great harmony, and had everything in Great plenty.... But alas, it is not so now, all our Fishing, Hunting and Fowling is entirely gone."

New England in 1800 was far different from the land the earliest European visitors had described. .. . Large areas particularly of southern New England were now devoid of animals which had once been common: beaver, deer, bear, turkey, wolf, and others had vanished. In their place were hordes of European grazing animals ......341

Destruction of game stocks had little adverse impact on the settlers who relied on domestic, not wild, animals for food and byproducts.

The same story played itself out on other frontiers. In 1796, George Washington reminded the "beloved" Cherokee "that the game with which your woods once abounded, are growing scarce. ${ }^{\text {,42 }}$ In 1820 , Andrew Jackson cited the total absence of game in counseling the Choctaws to remove to lands west of the Mississippi. ${ }^{343}$ In the 1809

${ }^{337}$ Id. A leader of Plymouth Plantation, discussing events preceding the First Thanksgiving, noted how in the colonists' first autumn they "began to come in store of fowl, as winter approached, of which this place did abound when they came first (but afterward decreased by degrees)." BRADFORD, supra note 254, at 90 .

${ }^{398}$ CRONON, supra note 307 , at 100 (quoting John Josselyn as stating, "tis very rare to meet with a wild turkie in the woods").

${ }^{399}$ STEEIE, supra note 204, at 94 (quoting Miantonomi, Chief of the Narragansett, Speech at Montauk (1642)).

${ }^{340}$ CRONON, supra note 307, at 107 (citing Harry Quaduaquid \& Robert Ashpo, Statement to the Most Honourable Assembly of the State of Connecticut (May 14, 1789)).

${ }^{341}$ Id. at 159 .

${ }^{342}$ President George Washington, Talk to the Cherokee Nation (Aug. 29, 1796), reprinted in GEORGE WASHINGTON: A COLLECTION 645 (William B. Allen ed., 1988).

${ }^{343}$ See REMINI, supra note 207, at 394 (contrasting land "abounding in game of all kinds" west of the Mississippi with the land east of the Mississippi where "game is destroyed"). 
negotiations with the Piankashaws for lands overlapping the United Companies' claims as the frontier moved westward from Ohio, Harrison reminded the Indians that " $[t]$ here was but little game left on the proposed tracts." Great Plains buffalo on western tribes is well-documented. ${ }^{345}$

From the nation's foundation, American leaders relied on the effect of European agriculture and husbandry on Indian game animals to shape policy. In an extremely influential letter, General Schuyler advised Congress to avoid expensive wars and to instead wait for nature to take its course.

[A]s our settlements approach their country, they must, from the scarcity of game, which that approach will induce to, retire farther back, and dispose of their lands, unless they dwindle comparatively to nothing, as all savages have done, who gain their sustenance by the chase, when compelled to live in the vicinity of civilized people, and thus leave us the country without the expence of a purchase, trifling as that will probably be. ${ }^{346}$

Washington whole-heartedly concurred, emphasizing the economy of letting settlers instead of soldiers dislodge the Indians.

[T] he Indians as has been observed in Genl Schuylers Letter will ever retreat as our Settlements advance upon them and they will be as ready to sell, as we are to buy; That it is the cheapest as well as the least distressing way of dealing with them, none who are acquainted with the Nature of Indian warfare, and has ever been at the trouble of estimating the expence of one, and comparing it with the cost of purchasing their Lands, will hesitate to acknowledge.

This view became orthodoxy among policymakers. In 1789, the Secretary of War, who was responsible for Indian affairs, "reasoned that as the settlers advanced toward the line between the whites and redmen's hunting grounds, the game upon which the natives relied so

${ }^{344}$ Smith, supra note 37 , at 225.

${ }^{945}$ See generally PATRICIA NELSON LIMERICK, THE LEGACY OF CONQUEST: THE UNBROKEN PAST OF THE AMERICAN WEST 182 (1987) ("[T] he Plains Indian way of life rested on the abundance of buffalo; the hide trade was the most direct way to make them a 'dying race." ).

${ }^{946}$ Letter from General Schuyler to Congress (July 29, 1783), in 3 PAPERS OF THE CONIINENTAL CONGRESS, 1774-1789, microformed on Nat'l Archives Film M-247, Fiche 173, at 593, 603:153 (National Archives Microfilm Publ.).

${ }^{347}$ Letter from George Washington to James Duane (Sept. 7, 1783), in WRrrINGS OF WASHINGTON, supra note 292, at 136 (emphasis added). In the same letter, Washington similarly argued that "the gradual extension of our Settlements will as certainly cause the Savage as the Wolf to retire; both being beasts of prey tho' they differ in shape." Id. at 140 . 
heavily retreated. The result was to be that new purchases could then be made for small considerations. ${ }^{348}$

Even the disastrous defeats of Generals Harmar and St. Clair in the early 1790s did not shake the Administration's belief that, come what may, settlers would inevitably push the Indians off their lands. When they promised to respect the Illinois and Wabash tribes' rights in their land,

[n] either Knox nor Washington had any real reason to think they were risking much by giving a guarantee of Indian land, for both of them had already expressed the view that a boundary line would never prove permanent as white settlement pressed up to the boundary. The Indians would either be exterminated, retire, or would easily yield land which was no longer useful to them.

They hoped for, and received, a military victory by General Wayne at Fallen Timbers in 1794, but they apparently did not view this as necessary to continued expropriation of Indian lands.

Game-thinning rendered lands less valuable to the tribes and thus made them simultaneously less willing to fight for the land and more willing to sell it cheaply. The Indians "most chearfully" acceded to a requested cession to indemnify victims of wartime depredations since the land in question "was now of no use to them, for Hunting Ground." 350 By contrast, the Shawnees fought so ferociously for Kentucky, as noted in M'Intosh, because "they often hunted [there] and they did not intend to have their supply of game disturbed."

Based on this economic consideration, the pace of the westward expansion of settlements set the pace for land purchases, for it was unnecessary and expensive to buy the still-valuable virgin forests the Indians valued highly.

The purchase will be as easy made at any future period as at this time. Indians having no ideas of wealth, and their numbers always lessening in the neighbourhood of our Settlements, their claims for compensation will likewise be diminished; and besides that, fewer will remain to be

${ }^{348}$ Bayard, supra note 220 , at 49.

349 HORSMAN, supra note 90 , at 95 .

${ }^{350}$ ABERNETHY, supra note 67, at 31, (quoting letter from George Croghan, Deputy Agent to Col. William Johnson, to Benjamin Franklin (Dec. 12, 1765)).

${ }^{351} I d$. at 98. In M'Intosh, Marshall reflected on Kentucky as "a country, every acre of which was then claimed and possessed by Indians, who maintained their title with as much persevering courage as was ever manifested by any people." Johnson v. M'Intosh, 21 U.S. (8 Wheat) 543, 586 (1823). 
gratified, the game will be greatly reduced, and lands destitute of game will, by hunters, be lightly esteemed. ${ }^{352}$

Similarly, the Indian agent at Fort Wayne in 1809 advised against pressure tactics to gain further cessions. He assured his superiors "that Indian lands would be easily obtainable at the proper time when they were no longer needed as hunting grounds. In the past, this condition had coincided with the needs of the espanding [sic] white settlements. ${ }^{353}$

\section{Understanding the Economic Impact of Game-Thinning}

While the effect of disease on the terms of trade between Americans and the tribes is clear, ${ }^{354}$ the effect of game-thinning requires further explication via an analogy. Consider two neighbors, a farmer and an industrialist who wishes to acquire the farmer's land. The farmer's land is uniquely valuable to the industrialist as part of a planned expansion. These parties are in a bilateral monopoly, like the ships Distress and Rescuer in the earlier hypothetical or the United States and the Indian tribes. ${ }^{355}$ Assume that the industrialist is willing to pay up to $\$ 200,000$ for the farm, while the farmer will settle for nothing less than $\$ 100,000$. The parties will then fight over the division of gains, since any price between these two extremes leaves both better off.

Now add a twist: the industrialist's everyday acts decrease the value of the land to the farmer (for example, smoke partially blocks the sun, stunts crop growth, and adversely affects animal health). The farmer will then be willing to sell out for less, say $\$ 50,000$. This does not guarantee that the industrialist will get the property for $\$ 50,000$ or even for less than $\$ 100,000$-if the farmer knows that the industrialist is willing to pay $\$ 200,000$ and is an adept bargainer, she may get a price near the top of the range and garner most of the gains from trade. All else equal, however, the industrialist is likely to get the land for less if she can reduce its value to the farmer. The range of mutually beneficially outcomes has expanded by fifty percent, and every point in the expansion favors the industrialist.

${ }^{352}$ HORSMAN, supra note 90, at 100, (quoting Letter from Col. Timothy Pickering to Rufus King, Congressman from Massachusetts (June 1, 1785), in 1 THE LIFE AND CORRESPONDENCE OF RUFUS KING 105 (Charles R. King ed., 1894)).

${ }^{353}$ Bayard, supra note 220, at 277.

${ }^{354}$ Reductions in the Indian populations eroded their ability to inflict military losses and thus strengthened the United States's bargaining position.

${ }^{355}$ See supra Part II.B.2 (illustrating bilateral monopolies using an example from marine salvage). 
The common law of nuisance provides a remedy for such negative externalities, allowing the farmer either to bar the industrialist's smoke-spewing or at least to collect damages. ${ }^{356}$ The distinction between injunctive relief and damages is usually important in nuisance cases: injunctive relief forces a polluter with a higher-value activity to bargain with others and perhaps share some of the surplus, while limiting plaintiffs to damages in effect allows a polluter to condemn a neighbor's use and enjoyment at the market value of the neighbor's use. When the polluter wants title to the neighbors' land, however, even damages prevent the polluter from improving her bargaining position by the effects her activity has on her neighbor. Properly calculated, damages will make the farmer whole again, and thus she will drop her suit against the industrialist and sell her the property only for $\$ 100,000$ or more.

A similar analysis applies if one replaces the farmer with the Indians, the industrialist with the United States, and smoke with the gamethinning that resulted from approaching settlement. By devaluing the Indians' hunting grounds, the United States significantly increased the range of favorable outcomes in its bargaining game with the Indians, and hence the odds of buying Indian lands cheaply. The Indians, of course, had no nuisance-like remedy for the negative external effect that neighboring settlements had on the land they retained. Game-thinning reduced the value of land to the tribes and thus tilted the odds yet further in favor of the United States in the process of bargaining for Indian land. While settlement and the game-thinning that necessarily followed are not classical expropriating acts like some of the bargaining techniques discussed above in Part II.B.2, they fall in a gray area between expropriation and voluntary exchange. The United States obtained land more cheaply based in part on negative external effects that the nation would not have tolerated among its own citizens.

${ }^{356}$ It is assumed here that the harm to the farmer arises as a necessary side effect of productive activity by the industrialist. If the industrialist engaged in acts otherwise legal, solely for the purpose of harming her neighbor, the common law would provide the farmer powerful remedies against such unproductive (indeed, counterproductive) activity. See generally POSNER, supra note 163, §6.15 ("Intentional Torts") (characterizing intentional torts that resemble common law crimes as coerced or forced transfers of wealth leading to economic waste and arguing that legal policy should be and has been more willing to award punitive damages in such cases).

${ }^{957}$ The classic discussion contrasting damages (liability rules) and injunctions (property rules) is Guido Calabresi \& A. Douglas Melamed, Property Rules, Liability Rules, and Inalienability: One View of the Cathedral, 85 HARV. L. REv. 1089 (1972). 


\section{E. Altering the Terms of Trade: Legal Rules to Attract Settlers and Deal with Externalities}

\section{Attracting and Rewarding Settlers}

\section{a. The Economics of Attracting and Rewarding Settlers}

To the extent the federal government discouraged, or at least did not actively encourage, settlement on the frontier, it would be difficult to charge the nation with engaging in quasi-expropriative acts against the Indians. The United States, however, was not passive. The government enacted laws that encouraged settlement on the distant, dangerous frontier. The need for settlers was obvious. Via the discovery doctrine, the M'Intosh rule, and the ability to extinguish Indian claims cheaply, the United States had claims to virtually limitless acres. Yet frontier land, unlike a prime address in Manhattan today or gold since recorded history, had no established market; it was valuable only to the extent that the nation could attract buyers.

At first blush, it seems unclear why America needed legal incentives to spur land purchases. There was a large pool of potential buyers, both domestic and foreign, ${ }^{358}$ and combined with the millions of acres available, it would seem conditions were ripe for an active market to emerge, with price adjusting to equilibrate the costs and benefits of moving to the frontier. There were, however, two prominent market failures that would have led to inefficiently low amounts of frontier settlement in the absence of some sort of governmental intervention.

First, settlers were better off coordinating their migrations (for stronger defense, more concentrated spreading of disease, and thinning game), but had difficulty doing so on a large scale privately. In addition to helping coordinate activity, the government helped deal with what is known as a network externality. ${ }^{359}$ Just as one of the main

${ }^{953}$ See generally SOSIN, supra note 225, at 23 ("Early marriage was the rule; and the birthrate among women of child-bearing age was exceptionally high in colonial America. In many colonies the population doubled every generation."). In addition, the desire to attract land purchasers played a role in the colonies' and the nation's opendoor immigration policies. SeeE. WIILARD MILLER \& RUBY M. MIILER, UNITED STATES IMMIGRATION: A REFERENCE HANDBOOK 3-4 (1996) (tracing the development of U.S. immigration policy from 1607 until the early 1800 s).

${ }^{359}$ The term "network externality" seems to have been coined in Michael L. Katz \& Carl Shapiro, Nelwork Exlemalities, Competition, and Compatibility, 75 AM. ECON. REv. 424, 424 (1985) ("[T] he utility that a given user derives from [a] good depends upon the number of other users who are in the same 'network' as is he or she. The scope of the 
attributes that makes a computer operating system like Windows $95^{360}$ valuable is the simple fact that many others use it (making skills transferable, software cheaper based on volume, etc.), so too, settlement on the frontier became safer and more economically attractive as the number of other settlers increased. The government not only needed to coordinate behavior, it needed to overcome a natural inertia: nobody wanted to be among the first on the frontier, bearing the greater risks. The government was also in a unique position to supply settlers with information about the safety and suitability for agriculture of various regions.

Second, settlers produced a host of positive external effects. As suggested in the previous paragraph and in Part II.D, the first settlers in a region spread disease and thinned game, reducing the value of neighboring lands to the Indians. This helped the nation purchase land cheaply and raised the value of nearby lands significantly. A Congressman expressed the western attitude by arguing that even squatters performed a service by improving the lands and increasing the value of neighboring tracts. ${ }^{361}$ The government's policy of reserving one section, "section 16," in the rectangular survey of each tract of land stemmed from a belief that the land would become more valuable after the first wave of settlers established themselves. ${ }^{362}$

In addition to enhancing the value of land in their immediate neighborhood, new settlers made land on the previous frontier less dangerous and hence more valuable. Squatters argued this point explicitly, noting that " $[t]$ hey had served as buffers in the recent war against the Indians, and their sacrifices had assured the safety of the towns and larger plantations [further east]..$^{363}$

These and perhaps other external effects seem to explain the "opinion that the Improving and cultivating the Land in Pennsylvania is a General Interest and Credit to the Province in Part as well as to the la-

network that gives rise to the consumption externalities will vary across markets."). For recent applications of the concept to legal problems, see Michael Klausner, Corporations, Comporate Lau, and Networks of Contracts, 81 VA. L. REV. 757, 763 (1995).

${ }^{360}$ Windows 95 is a trademark of the Microsoft Corporation.

361 See Letter from Congressman John McLean to James Monroe, Secretary of State (Jan. 19, 1816), reprinted in 8 TERRITORIAL PAPERS (1956), supra note 31, at 373-74 (1939) (arguing that a squatter "selects a valuable spot and renders it, (and the adjoining lands), more valuable by improvement").

${ }^{362}$ The New England tradition of "the reservation of section 16 in every township "for the maintenance of public schools within said township" became part of Federal land policy. PAUL W. GATES, HISTORY OF PUBLIC LAND LAW DEVELOPMENT 65 (1968).

${ }^{363}$ ROHRBOUGH, supra note 96 , at 110 (emphasis added). 
boring man that gets his living upon the Improvements." ${ }^{364}$ The problem with these benefits is that they did not inure to those creating them. Inability to award positive external effects to the source of the benefit leads to socially suboptimal outcomes: individuals will not engage in the efficient level of an activity for which some of the benefits end up in others' pockets. ${ }^{365}$

If sellers can somehow capture the positive external effects created by buyers, then competition will drive the price they charge down in order to internalize the benefits. In land sales, the recipients of the settlers' "services" were a broad class of other Americans, from those on the previous frontier who found themselves on safer and hence more valuable land, to all citizens whose direct or indirect tax burden would fall as western lands became more valuable and productive. The United States, then, could encourage the efficient level of settlement by discounting frontier lands below the market-clearing level. By offering land at a discount to settlers, the government encouraged more purchases by settlers. The taxpaying population, beneficiaries of the settlers' activities, would pay for this subsidy.

There was a long tradition of land subsidy measures in colonial times. American policy after the Revolution evolved from trying to charge relatively high prices (to pay off Revolutionary War debt) to offering land at lower prices, to including favorable financing terms, to permitting preemption (squatters' rights), and finally to outright giveaways (the Homestead Acts).

Before reaching these "discounting" policies, however, a number of legal rules that solved the coordination problem and enhanced the United States's natural advantages (disease and game-thinning) will

364 AMELIA ClEWLEY FORd, COLONIAL PRECEDENTS OF OUR NATIONAL LAND SYSTEM AS IT EXISTED IN 1800, at 133 (Univ. of Wis. Bull. No. 352, 1910) (quoting a Pennsylvania surveyor writing in 1738) (emphasis added). Squatters in Maine invoked similar logic, arguing that "the opening of Wilderness and turning the Desert Into Wheatfields, while it Supports Individuals, is of great advantage to the publick." Id. at 134-35.

${ }^{365}$ For an interesting example, see IAN AYRES \& STEVEN D. LEVITT, MEASURING POSTTIVE EXTERNAITTIES FROM UNOBSERVABLE VICTIM PRECAUTION: AN EMPIRICAI ANAIYSIS OF LOJACK (National Bureau of Econ. Research Working Paper No. 5928, 1997), available at <http://papers.nber.org/papers/W5928> (visited Mar. 30, 2000) (demonstrating that prevalence of hidden auto anti-theft devices in a given region deters car theft in general, so that purchasers of such devices confer positive external effect on non-purchasers). Lojack, and services rendered by settlers, are examples of "mixed" goods, for which there is both private and public demand. See RICHARD A. Musgrave \& Peggy B. Musgrave, Public Finance in Theory and Practice 49-55 (5th ed. 1989) (discussing costs and benefits of goods that serve both individuals and groups). 
be considered. Encouraging compact settlements served dual purposes: it solved the coordination problem by channeling settlers to those tracts the government surveyed and sold, and it concentrated, via relatively quick mass migrations, the effects of disease and gamethinning. Colonies and the United States had a long tradition of enhancing defenses by settling soldiers on the frontier. Requiring improvements, especially clearing of land, facilitated game-thinning. Large-scale land speculation, like that undertaken by the United Companies, undermined many of these advantages and hence laws generally disallowed it.

\section{b. Legal Rules to Attract and Reward Settlers}

This Part explains how some of the most important statutes of the early Republic, from the rectangular survey system to land sale financing, preemption acts, and homesteading, all played a role in efficiently expropriating Indian lands.

\section{i. Compactness and the Rectangular Survey System}

Attempts to keep settlement compact, especially in New England, date back almost to the beginning of colonization.

[T] o every person was given only one acre of land, to them and theirs, as near the town as might be; and they had no more till the seven years were expired. The reason was that they might be kept close together, both for more safety and defense, and the better improvement of the general employments.

This continued to be official policy for the next century, until the Indians had been all but eliminated from the region.

The necessity of "preserving a regular face to the frontiers" and of safeguarding sites for future towns caused the Massachusetts general court to begin to insist on contiguity. In addition, the needs of defence brought about the new plan of granting several townships simultaneously, to be located on the frontier. In 1713 the [Massachusetts legislature] resolved that it was for "Her Majesties Service [that] there be some Townships regularly Planted and Setled in the most Defensible manner, in [various outlying areas]..$^{367}$

Similar considerations motivated the British when they took over western policy from the colonies. In drawing a line between the races

\footnotetext{
${ }^{365}$ BRADFORD, supra note 254, at 145.

${ }^{367}$ FORD, supra note 364 , at 30 (internal citations omitted).
} 
in the Proclamation of 1763, Sir William Johnson wanted to encourage "thick settlement of the Frontiers" and to "oblige the Proprietors of large grants to get them Inhabited." "368 London rejected an earlier scheme to set up a colony in Illinois because it "had determined on the gradual expansion of the settlements westward," and Illinois was then far from the frontier. ${ }^{369}$

Although the nation did not ultimately adopt the highly organized approach of settling the frontier only in complete townships, the land sales regime generally followed the contiguous approach, selecting blocks of land for settlement and requiring surveys before sales.

The United States was concerned [all along the frontier] about the orderly advance of white settlement. It wanted to open lands adjacent to the established settlements and to discourage wide scattering of the whites to areas far distant, and the extinguishment of Indian titles by treaty proceeded pretty much in this fashion. ${ }^{370}$

The lynchpin of this orderly advance was the rectangular survey system. ${ }^{371}$ By refusing to sell land, and later refusing to recognize preemption (squatter) rights, before an area had been surveyed, the United States government exercised significant control over when settlers went to the frontier and where they went. Controlled, contiguous, concentrated land rushes into predesignated areas conferred a number of advantages in expropriating Indian lands at least cost. They enhanced the spread of endemic diseases and thinned game rapidly. Compact settlement made defending the frontier cheaper. Finally, the rectangular survey system, by channeling settlers at a given time to a few, select regions on the extensive frontier, solved their coordination problem and provided them, at low cost, with valuable information.

To illustrate this last point, consider a family contemplating migration to one of two frontier locations; call the two possibilities Illinois and Alabama. For all the reasons discussed above, they would like to go where everyone else is going. Yet the costs of communicating among thousands of families and coordinating their decisions

${ }^{36 s}$ PRUCFA, supra note 6, at 14.

$\$ 69$ ALVORD, supra note 312 , at 322 (emphasis added).

${ }^{370}$ PRUCFA, supra note 205, at 146 (emphasis added).

371 Bouquet, a British general, laid much of the foundation for the rectangular survey system in his design for a land system to help control the frontier. See FoRD, supra note 364 , at $37-38,53$ (" [His plan] shows a British officer studying settlement under frontier conditions, and reaching the same conclusion in theory as pioneers a decade or so later, worked out in practice under the same conditions." ). 
would be prohibitive. In the absence of effective communication, each family faced the dilemma illustrated by Figure 3 .

Every Other Family

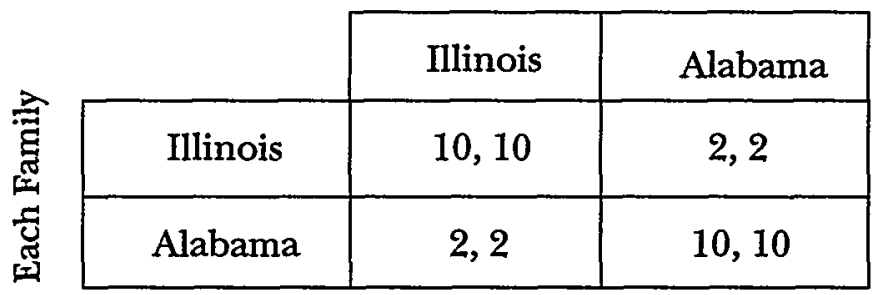

Payoffs: (Each Family, Every Other Family)

Figure 3

The payoffs in Figure 3 are somewhat arbitrary; they merely reflect that the settlers are better off together than apart. Unable to communicate in advance, the families are effectively playing a guessing game and have only a fifty percent chance of ending up in the same area. $^{372}$ If the total number of settlers wishing to migrate is sufficient to defend effectively, spread disease, and thin game in only one region, having half the group migrate to Illinois and the other half to Alabama is not an efficient way to extinguish Indian claims. The government can solve this problem by opening up settlement first in one region, say Illinois, and then, after Illinois is sufficiently populated, surveying and opening up Alabama.

Assume in addition that Illinois is safer than Alabama. This would change the payoffs in the upper left corner to, say, $(15,15)$. One of the cheapest ways for the government to communicate this to migrants is simply to open up Illinois lands first. It need not attempt actually to notify potential settlers about the disadvantages of other regions; it can simply refuse to sell land until the region is the most advantageous place for settlement. These appear to have been the motivations for the facets of the rectangular survey system and the "orderly" advance of the frontier described above.

The United States rejected the competing system of "indiscrimi-

${ }^{372}$ This scenario is often called a "coordination game," indicating that the only thing the parties need to do in order to maximize their payoffs is to coordinate their choices; there is no inherent conflict created by the payoffs. See ERIC RASMUSEN, GAMES \& INFORMATION 26-27 (2d ed. 1994), for a description of coordination games. 
nate location" prevalent in the South, where purchasers received the right to select a given number of acres anywhere in a colony, as long as there was no preexisting claim. The problem with indiscriminate location was that "good lands, especially the river bottoms, were taken up rapidly. Newcomers pushed farther and farther into the wilderness in search of good lands without bothering about the nearer but second-rate stretches. Thus, new regions quickly became dotted with widely scattered and often unconnected settlements. ${ }^{, 373}$ This created four disadvantages relative to compact settlement in extinguishing Indian claims at low cost. First, scattered settlement thinned game and spread disease less effectively in a given region than compact settlement. Second, it left unsolved the coordination problem among settlers who would benefit from migrating to the same area as other settlers but would have a difficult time coordinating the joint migration themselves. Third, dispersed settlers were less able to defend themselves and hence more reliant on the military services of the government $^{374}$ Finally, scattered settlement left the government with less valuable reserved lands, making it more difficult to subsidize the initial settlers and recoup the positive externalities by selling neighboring lands later at a higher price. ${ }^{375}$

The government's belief that land prices would rise rapidly in the aftermath of settlement explains in part the reservation of section 16 of each township from sale, a practice dating back to colonial times. ${ }^{376}$

${ }^{373}$ Rudolf Freund, Military Bounly Lands and the Origins of the Public Domain, 20 AGRICULTURAI HIST. 8, 12 (1946).

${ }^{374}$ A contemporary commentator cataloged the military advantages of compact settlement over indiscriminate surveys:

This method will push our settlements out in close columns, much less assailable by the enemy, and more easily defended, than extensive, thin populations; there will be people here for defense near lhe fronliers; they will have the inducements of a near interest to animate them to the service; their course of life and acquaintance with the country will render them much more fit for the service, than people drawn from the interior parts of the country; and the necessary force may be collected and put into action much quicker, and with much less expense, than if the same was drawn from distant parts.

WEBSTER, supra note 297 , at 493 .

As a matter of economics, it might seem that a government selling under the indiscriminate survey system could have accepted a lower price in return for requiring its widely-scattered settlers to defend themselves. As discussed infra Part II.E.2, however, any government that wanted to sell frontier lands needed to foster a reputation for protecting its settlers.

${ }^{375}$ Such lures were efficient given the positive external effects of settlement.

${ }^{376}$ The Penns, proprietors of Pennsylvania, "reserved [land] in order to secure the unearned increment [from development]." VOLWILER, supra note 312, at 238. Maine landowners reserved every third lot, also hoping to sell later when positive externalities 
Charging a higher price later for these reserved sections enabled the government to charge lower prices to the first settlers. Offering a discount to early settlers may have been necessary to counteract higher costs incurred by those first settling a frontier. Consider the following scenario:

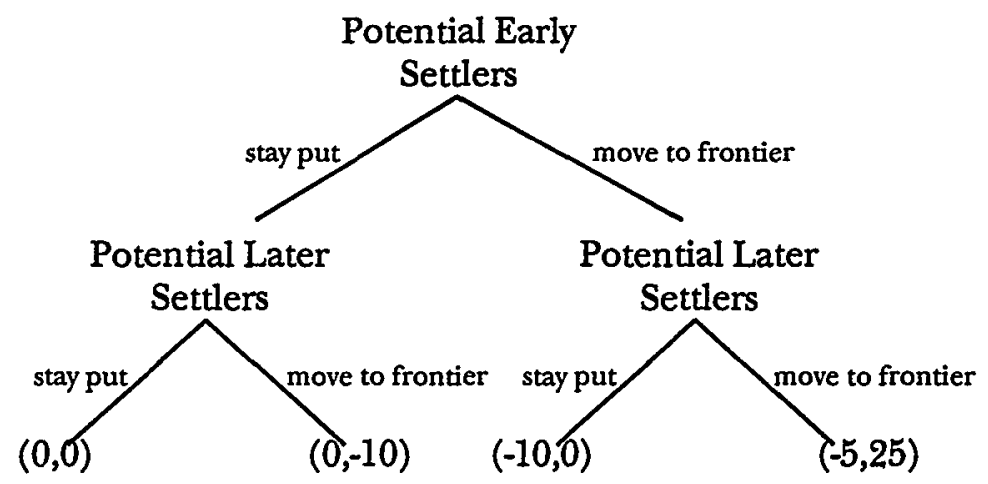

Payoffs: (early settlers, later settlers)

Figure 4

If nobody moves, there are no losses but also no gains, illustrated by the $(0,0)$ payoff on the left. Those who move first to the frontier face greater risks, more distant markets, and a host of other costs. Early settlers will not recoup these costs if nobody follows them, as shown by the $(0,-10)$ and $(-10,0)$ payoffs in the middle two entries. Finally, early settlers recoup only part of their losses if others follow, while the later settlers reap a windfall by taking advantage of the pioneering done by their predecessors, demonstrated by the $(-5,25)$ entry on the right.

Facing these choices and making individualized self-interested decisions, the parties would both stay put. The potential early settlers do better if they stay put regardless of what potential later settlers might decide. Once the early settlers decide to stay home, the potential later settlers have no incentive to incur the costs of being the first ones on the frontier. The problem is that the outcome reached, $(0,0)$, is clearly suboptimal: the parties maximize their joint wealth by both moving to the frontier.

made the unsold parcels more valuable. See FORD, supra note 364, at 101 (discussing this practice as used in Augusta, Maine). As discussed supra note 70, the expectations must have been that land prices would rise faster than the risk-adjusted rate of interest. 
One obvious way to solve this dilemma, side-payments from later to earlier settlers, seems to involve prohibitive transactions costs. The government, however, as seller of all acreage to both groups, can simulate such side-payments by charging higher prices to late arrivals. This was precisely the effect of many federal land law rules: the reservation of section 16 , providing financing only to the first wave of settlers, and the Homestead Acts.

Reserving some land from sale also inspired confidence in potential settlers. Even if leaders were not confident that prices would rise rapidly enough to justify keeping some land off the market, retaining title to a portion of the frontier made the rest of the nation in effect co-adventurers with actual pioneers. Like an entrepreneur who retains a stake in an enterprise even after going public, this fostered confidence in potential settlers that the entity sponsoring the enterprise of expropriating Indian lands was confident of its success. In the same vein, by taking a fixed section of effectively random quality instead of the best lands, the United States looked less like a skittish secured creditor and more like a confident equity investor.

\section{ii. Special Programs for Special Abilities: Military Bounties}

Not all settlers were equally suited to frontier life. Early American colonists, following practice dating back at least as far as the Greeks, ${ }^{377}$ used "military bounties to promote compact settlement on the frontier by men able to defend it, and in this way to secure protection without the expense of a standing army." ${ }^{378}$ This process began in Virginia no later than 1679 , when the government granted large tracts to two militia officers on condition that they settle 250 men, at least fifty armed and ready for war; similarly, a 1701 statute offered land to groups that could maintain one armed soldier for each 500 acres granted. ${ }^{379}$ These special programs for veterans were not, in the main,

s77 See Jerry A. O'Callaghan, The War Velerans and the Public Land, in THE PUBLIC LANDS, supra note 100, at 109, 109 (citing Herodotus as mentioning the Greek practice of settling veteran soldiers on new frontiers).

${ }^{378}$ FORD, supra note 364 , at 103-04.

979 See 2 STATUTES AT LARGE OF VIRGINIA, supra note 46, at 448-54 (granting tracts of land to Laurence Smith and William Bird, and stating that other lands on the frontier may be granted in the same manner); $3 \mathrm{id}$. at 204-06 (encouraging settlers by granting land to groups fulfilling certain requirements, including size). According to Ford, there were no takers at the time. See FORD, supra note 364, at 104 (discussing the statutes and concluding that "[n]othing came of this project"). Such statutes sound positively feudal, akin to requirements that lords of the manor maintain so many armed knights and the like. The threats posed by Indians in America, just as by war- 
compensation for services rendered; "settlement rather than reward was the object of [these] military bounties." ${ }^{330}$

Governments wanted to subdue the frontier, and there were natural gains from trade there: land in return for expertise in fighting Indians. Building on this longstanding practice, President Washington argued

that [western lands] could not "be so advantageously settled by any other class of men as by the disbanded officers and soldiers of the army," for this plan of colonization "would connect our government with the frontiers, extend our settlements progressively, and plant a brave, a hardy and respectable race of people as our advanced post, who would be always ready and willing (in case of hostility) to combat the savages and check their incursions. ${ }^{331}$

He further argued that the presence of military men "would be the most likely means to enable us to purchase upon equitable terms of the Aborigines their right of preoccupancy; and to induce them to relinquish our Territories"; 382 by "equitable" Washington undoubtedly meant "cheap." He believed, then, that the presence of veterans on the frontier would help tilt the terms of trade for Indian lands in the nation's favor.

While the federal and state governments did award land bounties to Revolutionary War veterans and set aside a number of large western tracts to satisfy these claims, ${ }^{393}$ few veterans actually settled on the frontier. "The soldiers, in general, returned to their own homes and accustomed habits and few of them took any interest in lands in the wilderness except to assign their warrant, for a nominal consideration, to some restless settler or visionary speculator." ${ }^{884}$ Apparently the soldiers found the government's terms insufficiently attractive; if the nation wished to benefit from the positive external effect of using them as a buffer on the frontier, it needed to pay them more, for example, in the form of larger land grants, and further couple the interest with a settlement requirement.

Based on this experience, the government cooled on the idea of

ring princes, Vikings, and other marauders in medieval times, required both societies to structure themselves around, and devote considerable resources to, defense.

${ }^{380}$ FORD, supra note 364 , at 104.

${ }^{381}$ TREAT, supra note 88, at 21-22 (quoting George Washington, from WRITINGS OF WASHINGTON, supra note 292 , at 17).

${ }^{382}$ WRITINGS OF WASHINGTON, supra note 292 , at 17-18.

sss See, e.g., GATES, supra note 64, at 249-84 (discussing American military bounty land policies regarding Revolutionary War veterans).

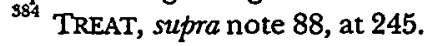


granting free land to veterans. Congress balked when veterans of William Henry Harrison's Tippecanoe campaign asked for land grants in the territories that Harrison had purchased. ${ }^{335}$ The veterans noted that "it would be of immen[s]e advantage to the security of the frontiers as well as to the future settlement of this extensive region .... [T] his plan of fortifying and securing the country from the hostility of the savages ... is not only the cheapest to Government but the most beneficial to your Soldiers and citizens." ${ }^{336}$ Another petition for land claimed that veterans could save the government $\$ 160,000$ a year in military outlays. ${ }^{387}$ Congress received over a dozen such petitions; all appear to have been defeated. ${ }^{38 s}$ Legislators, learning from past failures, undoubtedly worried that most grantees would simply sell their rights to other less martial settlers. Since the nation would not benefit from the positive externalities of a more skilled frontier population, there was no reason to grant land at a discount.

\section{iii. Requiring Improvements}

If and when the government granted lands on what it viewed as favorable terms, it naturally wanted something in return. Far more common than requests for military service were requirements that purchasers clear land and make other improvements. Virginia imposed such requirements on early settlers; ${ }^{389}$ its "ancient cultivation" statutes even rewarded squatters with title, despite their lack of legal right, as long as they cleared sufficient acreage. ${ }^{390}$ Massachusetts required settlers to clear at least five acres of land and build a house to perfect title. ${ }^{391}$ The British government followed similar policies, void-

${ }^{395}$ See John Arnold et al., Petition to Congress by Jolın Arnold and Others, reprinted in 8 TERRITORIAL PAPERS, supra note 31, at 219, 219-20 (1939) (asking Congress, as veterans, for a land grant).

836 TERRITORIAL PAPERS, supra note 31, at 220 (1939).

${ }^{597} I d$. at 318 (' $[W]$ ithin Nine Months after a proclamation ... the Ranging Business might cease and thereby Save the Expence of upwards of one hundred and Sixty thousand dollars per Year in this Territory....").

${ }^{388}$ See, e.g., 9 JOURNAL OF THE HOUSE OF REPRESENTATIVES OF THE UNITED STATES 304, 317, 397, 669-70, 743 (D.C., Gales \& Seaton 1826). For descriptions of some of these bills, see SAMUEL R. BROWN, VIEWS OF THE CAMPAIGNS OF THE NORTH-WESTERN ARMY 122-26 (Burlington, Vt, Mills 1814).

${ }^{389}$ SeeW. STITT ROBINSON, MOTHER EARTH: LAND GRANTS IN VIRGINIA, 1607-1699, at 31-32 (1957) (describing Virginia's land improvement requirements).

${ }^{390}$ See 3 STATUTES AT LARGE OF VIRGINIA, supra note 46 , at 206-07 (exempting settlers from specific duties upon fulfillment of certain conditions, including that they protect and build on the land).

${ }^{991}$ See FORD, supra note 364, at 103 (describing how Massachusetts homestead law 
ing patents if settlers did not occupy, improve, and cultivate land within a reasonable time. ${ }^{392}$ These colonial laws were precursors to the two primary subsidized land distribution systems later employed by the United States: preemption and homesteading. ${ }^{393}$ The technical differences among these programs are dwarfed by a single similarity: they rewarded only those who improved land, especially those who cleared forests for agriculture. These laws created incentives for settlers to destroy animal habitats and thus to thin the game relied on by the Indians. This in turn reduced the value of the lands to the Indians, who would then be less likely to fight, and would more likely part with their title of occupancy for a lower price. ${ }^{304}$ Clearing land, then, had positive external effects, and the government tailored land policy to maximize this benefit to all colonists.

\section{iv. Disfavoring Large-Scale Speculation}

In a few early instances, the government sold land at a discount to large entities that aimed to profit from marketing smaller parcels to individual settlers. For instance, the Ohio Company bought an enormous tract of land in eastern Ohio for ten cents an acre at a time when the government was trying to sell to settlers at two dollars an acre. ${ }^{395}$ Yet as time went on the government rarely resorted to such middlemen. ${ }^{396}$ As part of settling the frontier at least cost, it is surprising that the government did not make greater use of private enterprises like the Ohio Company or the earlier United Companies. While the government needed to prevent competition in acquiring Indian title, it is natural to presume that once it obtained title, private enterprise would have had a cost advantage in undertaking the myriad

required settlers to take "actual possession and within three years, build[] a house of a certain size, usually eighteen or twenty feet square, and clear[] five to eight acres fit for mowing and tilling").

${ }^{392}$ See VOLWILER, supra note 312 , at 243 ("They declared a grant null and void unless a certain proportion of the land was cultivated and settled within a reasonable period of time.").

${ }^{393}$ See infra notes 419-39 and accompanying text (discussing these two distribution systems at length).

${ }^{994}$ See supra Part II.D.2-.3 (discussing the game-thinning effects of settlement and the resulting decrease in the value of the land to the Indians).

${ }^{395}$ See ROHRBOUGH, supra note 96 , at 11 (describing Congress's sale of one million acres to the Ohio Company as an indication of its willingness to "rid itself of the expense and difficulty of administering a large section of the public domain," and of the need for immediate revenue).

${ }^{390}$ See id. at 12, 23 (noting the drop in sales to middlemen and the rise in sales to individuals at the end of the 18th century and beginning of the 19th). 
steps necessary to distribute the land to settlers. Nothing about land distribution leads one to believe it was a public good that private markets could not provide.

The positive external effects created by settlers, however, made land purchases in part a public good, or what the literature dubs a "mixed good": part private (benefits that accrued to settlers), and part public (positive external effects on their neighbors, those on the previous frontier, and others). ${ }^{397}$ The nation needed to subsidize the price of land in order to encourage settlement and optimize positive external effects. Accordingly, it offered settlers discounted land when it sold directly to them. ${ }^{398}$ When it sold large tracts to speculating enterprises like the Ohio Company, the nation adopted the same strategy. ${ }^{399}$

There are, however, two intertwined problems with trying to distribute privately a mixed good that creates positive external effects. At first cut, larger entities appear more attractive: the bigger the tract of land sold, the greater the positive external effects the seller can capture. A very large land distributor could, for instance, sell its first tracts cheaply, and successively raise prices for late arrivals facing less risk. This is precisely what the United Companies intended to do; they planned to offer free land to the first 500 families, apparently believing that they could more than recoup this giveaway by selling remaining land at higher prices. ${ }^{400}$ As large landholders, they could afford to subsidize early settlers since they captured a large share, if not all, of their positive external effects in the form of rising value for their unsold acres. This was common practice among large private landowners trying to attract settlers, from Maine to New York to Ohio. ${ }^{401}$ As long as the government offered the proper discount, large

${ }^{397}$ See MUSGRAVE \& MUSGRAVE, supra note 365 , at 49 (explaining that there is not such "a sharp distinction . . . between private goods ... and others, ... the benefits of which are wholly external").

${ }_{393}$ See supra Part II.E.1.b (describing financing, preemption, and the Homestead Acts).

${ }^{399}$ See infra Part II.E.1.b.v (discussing such discounted offers).

400 See Minutes of the United Companies, supra note 66, at 24.

401 "[E]ntrepreneurs... attracted settlers and subsidized them, thus helping to build up the back country.... [G] reat landed proprietors ... often supplied [buyers] with credit and other necessities for beginning a new community.... [Some] constructed roads, mills, and other improvements," and offered food, instruction in agriculture, churches, schools, and physicians. SosIN, supra note 225, at 40,42 . These land marketers "furthered the expansion and population of the back country by providing the economic wherewithal and services for prospective settlers who lacked means to establish themselves on the frontier." Id. at 43 . 
land distributors could pass on some of the discount to attract the optimal number of settlers, since they could capture the positive external effects of the earlier settlers by charging more to latecomers.

In the limit, this calls for selecting only one very large land distributor. Such a monopolist, however, will not make decisions that maximize social wealth, but rather will maximize its own profits. This always creates deadweight loss, but the social loss is even greater in the presence of positive external effects. ${ }^{402}$

In addition to ignoring the positive external effects of settlers' activities, monopolists reduce output below an efficient level to maximize their private profits. Thus, despite the sale of land to an entity with lower distribution costs, the monopolistic nature of that entity leads to an even greater divergence from the socially optimal level of settlement.

One way to deal with monopolies is regulation. When the government sold large tracts of land to speculators, it tried to mandate minimum requirements on the number of actual settlers. This is like requiring a monopolist to produce a given quantity, or, equivalently, to charge a given price. Thus, the British government conditioned the title of the Ohio Company of Virginia (unrelated to the later Ohio Company) on the settlement of 200 families; the United States imposed similar requirements on the Ohio Company. ${ }^{403}$ Monitoring compliance with such restrictions and punishing violations, however, was expensive.

The more natural solution to monopoly is competition: the government could have sold discounted land to a large number of speculators. The discount would have solved the positive externality problem. Further, rivalry among the speculators would seem to solve the monopoly problem since competition to attract settlers would cause the groups to increase output, and simultaneously lower their price, until they earned only enough to cover their costs of distribution. It would seem, then, that the government could have the best of everything: acquire the land cheaply itself, turn around and sell it at prices calibrated to capture the positive externalities of settlement, and the buying entities could distribute the land to settlers at lower cost than the state.

These distribution companies, however, faced the network exter-

${ }^{402}$ See supra Figure 4 (mapping out the choices faced by early and later settlers).

${ }^{403}$ See SOSIN, supra note 225 , at 33 ("In 1752 [the Ohio Company] received an additional 300,000 acres conditional on settling 200 families."). 
nality problem: ${ }^{404}$ each would prefer owners of neighboring tracts to market their lands first, allowing the later seller to reap the positive external effects created by the earlier settlement. Pelatiah Webster voiced precisely this concern in arguing for small tracts in compact settlements instead of large sales to speculating companies. He worried about

large quantities of land lying unimproved in the hands of non-residents or absentees, who neither dwell on the land, nor cause it to be cultivated at all, but their land lies in its wild state, a refuge for bears, wolves, and other beasts of prey, ready to devour the produce of the neighbouring farmers, bears no part of the burden of first cultivation, and keeps the settlers at an inconvenient distance from each other, and obstructs the growth and riches of the townships in which it lies; whilst the owner, by the rise of the land, makes a fortune out of the labor and toils of the neighboring cultivators. This is a most cruel way of enriching one man by the labor of another, and so very hurtful to the cultivation of the country, that it ought to be restrained by the most decisive measures.

Those making a "fortune" out of the "rise of the land [prices]" due to the "labor and toils" of their neighbors are free riders capturing the positive external effects created by earlier settlers. This externality problem and the network externality problem create more than an issue of justice. As Webster emphasizes, these problems adversely affected efficiency. They create inertia, as each Company or settler waits for others to go first; to the extent actors foresee this problem they may simply choose not to participate in the market.

Any attempt to pursue both governmental and private land sales faced the same problem. The government, focusing on social welfare, would subsidize prices sufficiently to lure settlers to its portions of the frontier, while private distributors would wait until buyers from the government generated positive external effects that raised the value of the neighboring lands they owned. The private sellers could free-ride, cutting into the government's ability to subsidize settlement. This explains why speculators often withheld land from the market. It also undermined some of the positive external effects of compact settlement.

The effects on settlement of the extensive purchase of land by speculators were very great. Desirable tracts in the neighborhood of settlements were held at prices too high for most of the immigrants to pay, and consequently they were forced to go farther afield to take up less desirable land.

\footnotetext{
404 See supra Part II.E.I.a (exploring the network externality problem).

${ }^{405}$ WEBSTER, supra note 297 , at 494.
} 
The result of this and of the uniform price of government land, regardless of quality, was a widespread scattering of the settlers over a vast extent of territory instead of an orderly progression along a definite frontier. ${ }^{406}$

The United Companies explicitly recognized that many governmental acts had enhanced the value of their claims, and stated their willingness to cede a large portion of the land to the United States to reflect the nation's contribution to its value. ${ }^{407}$ Thus, it was up to the government to subsidize, in one way or another, land purchases by early settlers who generated positive external effects.

Before examining the means by which the colonial and national governments provided such subsidies, it is interesting to consider one means the government did not employ: small-scale speculation. Instead of selling small tracts of land at a deeply discounted price to the first wave of settlers, the government could have sold larger tracts at a small discount. The settlers then could have resold the extra acreage at a higher price, after their activities had rendered the area safer and more economically viable. Many pioneers engaged in such small-scale speculation themselves, buying up the claims of neighbors who either decided not to move west or decided not to stay. ${ }^{408}$

\section{v. Discounts to Attract the Masses}

Thus, those who wished to speculate had to buy neighboring lands themselves; the government did not give out excess land as a means of

${ }^{406}$ BuCK, supra note 97 , at 58 (emphasis added). There is a longstanding historical debate on the role of speculators in settling the frontier. Traditional scholarship condemned them as parasites. However, more economically sophisticated analyses have defended their role in efficiently distributing land. For a summary of this literature, see Robert P. Swierenga, Land Speculation and Its Impacl on American Economic Growth and Welfare: A Historiographical Review, 8 W. HIST. Q. 283 (1977).

${ }^{407}$ While formally maintaining a right to the entirety of the lands described in two deeds, the Companies were "ready to admit, that the measures adopted by the Government for the defence and settlement of the neighboring country have greatly enhanced the value of this property," and hence were willing to yield a portion of their lands. 1810 MEMORIAL, supra note 81, at 116.

${ }^{408}$ See Stephen Aron, Pioneers $\mathcal{E}^{2}$ Profiteers: Land Speculation and the Homestead Ethic in Frontier Kentucky, 23 W. HIST. Q. 179, 182 (1992) ("[B]ackcountry men ... were [equally] susceptible to unrestrained acquisitiveness when it came to possessing land."). Aron points out that such speculation was inconsistent with pioneer rhetoric that denounced large-scale speculators for engrossing the best lands and charging excessive prices to hard-working settlers. The essence of the "homestead ethic" was that nobody should be able to buy more land than they could farm themselves. Id. at 182, 193. While the settlers' land speculation may have contradicted the rhetoric of their ethic, it was entirely consistent with efficient expropriation of Indian land, providing one way for pioneers to capture the positive external effects they generated. 
encouraging settlement. The United States, however, following a long line of colonial precedents, did subsidize frontier settlement in a whole host of other ways. "At times provincial governments encouraged joint ventures by offering townships with free land, tax exemptions, subsidies, agricultural implements, and supplies." land to encourage immigration were common, and appear to have been motivated by the positive external effects of settlement. ${ }^{40}$ The result was cheap land. "[D] ue to the desire of the royal and various colonial governments to establish a bulwark of settlers in the back country, by the middle of the eighteenth century even those with very limited means could legally obtain tracts." ${ }^{\text {"11 }}$ The granting government usually apportioned subsidies based on the number of ablebodied men who would settle on the frontier. For instance, colonial Virginia's "headright" system awarded fifty acres for each immigrant ${ }^{412}$ New settlers, beyond the positive external benefits they conferred on existing settlers, were cheaper frontier defenders than soldiers.

"[B]uffers" had formed a protective shield on innumerable occasions since the establishment of the English colonies. Various colonial governments in periods of crisis had offered free land to men who would settle in exposed places. The prosperous citizens of the General Court in Massachusetts and the House of Burgesses in Virginia thought such bounty cheaper than the cost of mercenary troops and perhaps even more effective.

Selling land at market prices in the presence of positive external benefits would have been suboptimal. ${ }^{414}$ Therefore, "[r]egardless of

${ }^{409}$ SOSIN, supra note 225 , at 40 . Even with these subsidies, some so extensive that they amounted to a negative price for land (paying settlers to occupy it), colonial governments found it difficult to lure settlers to the remote and dangerous frontier. They turned their attention to disfavored groups with lower opportunity costs. For instance, Georgia transported Jewish and other religious refugees across the ocean and supported them during their first years in order to create a buffer zone on the frontier. See PHinizy Spalding, Oglethorpe In AMERICA 4, 20 (1977) (describing the early colonization of Georgia and the settlers' unusual acceptance of Jews into the community). Georgia even banned importation of slaves at times, in an attempt to create a labor market with wages sufficiently high to attract European settlers to the frontier. See id. at 48-51, 60-61, 72 (explaining attempts "to keep Georgia a refuge for free, white, Protestant Yeoman farmers").

${ }^{410}$ See FORD, supra note 364, at 133 (quoting surveyor's observation that squatters improve land, stimulate the market, and increase state revenue).

4 SosIN, supra note 225, at 25.

${ }^{412}$ ROBINSON, supra note 389, at 32-33 (describing Virginia's "principal basis for title to land in the seventeenth century").

413 ROHRBOUGH, supra note 96, at 61-62.

${ }^{414}$ See supra Part II.E.1.a (arguing that "if sellers can somehow capture the positive 
the need for revenue from land sales, most states offered fairly generous terms to bona fide settlers or to squatters." different for the federal government immediately after the Revolution. It alone bore responsibility for repaying the huge debt incurred to fight the war, and hence felt great pressure to raise revenue to meet its obligations. Thus, in the early years of the Republic, the federal government offered few subsidies to purchasers of frontier lands.

This state of affairs, with the attendant sacrifice of all the positive external effects of greater frontier settlement, did not last long. In 1791, a land commissioner in Indiana recommended gifting land to French family heads even if they had no legal claim, arguing that they would prove useful in defending the region against Indians. ${ }^{416}$ Congress agreed and liberalized the standard for granting land to French inhabitants. ${ }^{417}$

In the same year, Congress began to sell land on credit; it followed with more generous terms in $1800{ }^{418}$ Private credit was apparently hard to come by, at least at the rates the government offered, and hence this was just another form of subsidy.

Under the Act of 1800 the land system became a real factor in the westward movement, and it was the five-year credit period which rendered the act effective. Without the credit little land could be sold for two dollars an acre, but with it a man could pay fifty cents an acre and the balance within five years. ${ }^{419}$

Congress also began to reconsider its treatment of squatters who made improvements on land without color of title, even those who trespassed on tribal lands before the United States, per M'Intosh, had extinguished Indian title. Squatters argued early and often that, at a minimum, they should have preemption-a right of first refusal to purchase, at a price determined by statute, the parcel of land that they had improved. As the war debt became less pressing, Congress began to listen.

external effects created by buyers, then competition will drive the price they charge down in order to internalize the benefits").

${ }^{415}$ Sosin, supra note 225, at 152.

${ }^{416}$ See Report Regarding Land Claimants in the Northwestern Terrilory (Dec. 23, 1790), reprinted in AMERICAN STATE PAPERS, supra note 81, I PUBLIC LANDS 9-10 (1832) (providing an account of the many methods of land disposal used by the various colonies).

${ }^{417}$ See Act of Mar. 3, 1791, ch. 27, 1 Stat. 221 (1791).

${ }^{418}$ See Act of May 10, 1800, ch. 55, 2 Stat. 73 (1800) (establishing four land offices, enjoining the surveyor general to transmit "general plats of the lands hereby directed to be sold" to those offices, and establishing the system by which the lands in question were to be divided).

${ }^{419}$ TREAT, supra note 88 , at 378-79. 
The growth of the sentiment in favor of preemption, therefore, was parallel to the changing conception of the ultimate object of land legislation. So long as revenue was the end to be sought, preemption was undeniably bad. But if the furtherance of settlement was to be the desire of Congress, then preemption was but a step toward the ultimate goal-the granting of homesteads to settlers. So during the half century of land legislation the squatter developed from a trespasser . . . to a public benefactor, a man whose bravery and whose sacrifices had opened great areas to peaceful settlement and who merited well of the nation.

What made a settler a "public benefactor" were the positive external effects his settlement had on neighbors and the rest of the nation. Selling frontier land at market prices inefficiently bypassed this public benefit. "Gradually [Congress] began to adopt the point of view of the pioneers, until by 1820 it had become the custom to grant preemption for a limited period in every region where, for special reasons, the land sales were delayed." ${ }^{421}$ One of the earliest and most important preemption acts was passed in $\mathbf{1 8 1 3}$ for squatters in Illinois; it served as "a prototype for later special preemption laws." of 1812 delayed government surveys and sales, yet the region was otherwise ripe for a deluge of settlers. To attract them despite administrative delays, and perhaps to help weaken the Indian resistance responsible for the delays, the government unleashed squatters to help reduce the value of the land to the tribes.

Preemption seems inconsistent with compact settlement since settlers have incentives to seek out valuable tracts, such as riverfront tracts, regardless of the location of other settlers. Douglas Allen, however, has noted that the preemption acts effectively prevented a return to the southern system of indiscriminate surveys. "The most notable feature [of the preemption acts] was that squatters only had preemptive rights on surveyed land. ${ }^{\text {"23 }}$ By limiting preemption to surveyed land, the government could solve the settlers' coordination problem and channel them to areas where they could best serve the process of efficiently expropriating Indian lands.

${ }^{420} I d$. at 386.

421 Id. at 383 .

422 ROHRBOUGH, supra note 96 , at 201. Many of the Illinois squatters who benefited from this act undoubtedly resided on lands claimed by the United Companies.

${ }^{423}$ Allen, supra note 17, at 19 (emphasis added). Allen notes that the government did recognize squatters on unsurveyed lands at times. He argues that this was done when hostile Indians made surveys impossible, as in Illinois around the time of the War of 1812. See id. at 20-21 ("With no reliable survey, homesteading in very hostile areas could not be carried out, and preemption may have been a viable alternative to military action."). 
When the United States went one step further and gave away land to improving occupiers, it similarly limited such gifts to the most distant frontier regions where Indians presented a real threat. In 1788, for instance, the Confederation donated 400 acres to every head of a household in Illinois and Indiana-a region over which hostile tribes exercised significant control. ${ }^{424}$ In 1802 , Congress gave away land in Mississippi, Alabama, Louisiana, and Arkansas, which were states on a contested border. ${ }^{425}$ Giveaways in Missouri and Michigan also occurred before the government had cleared these areas of hostile tribes. ${ }^{426}$ In addition, the government channeled settlers to Florida as part of its efforts to pacify the Seminole and other Florida tribes that zealously resisted American incursions.

The Armed Occupation Act of 1842 is the most obvious case of homesteading to induce settlement in the face of Indian problems. Spain had tried several times to place settlements in Florida, but failed for the most part because of the hostile Indians. The act of 1842 gave 160 acres to any man capable of bearing arms who was willing to move south of Gainesville and improve the land for five years. The policy was a success. Of the 200,000 acres allotted, 1,048 permits for 167,680 acres were taken up within two years. ${ }^{427}$

These limited programs were precursors to the most massive land "giveaway" in history: the Homestead Act of 1862 and successor legislation. ${ }^{428}$ The Homestead Acts vested title to anywhere from eighty to 640 acres to those who actually occupied and improved the land. The government did not offer choice tracts to homesteaders. Instead, it opened up only less desirable lands that were further from settlement. Moreover, the government usually limited homesteading to a few areas. "By instigating homesteading, the U.S. government restricted the choices of settlers by providing an incentive to rush one area., ${ }^{\$ 29}$

In the absence of positive external effects, homesteading (giveaways requiring occupation and improvement) creates a wasteful race

${ }^{424}$ See Act of Mar. 3, 1791, ch. 27, 1 Stat. 221 (giving 400 acres to persons "who in the year one thousand seven hundred and eighty-three, were heads of families at Vincennes or in the Illinois country, on the Mississippi").

${ }^{425}$ See Act of Mar. 3, 1803, ch. 27, 2 Stat. 229 (disposing of land in the Mississippi Territory).

${ }^{426}$ See Act of Mar. 3, 1807, ch. 34, 2 Stat. 437 (regulating grants of land in Michigan); Act of Mar. 27, 1804, ch. 61, 2 Stat. 303 (regulating grants of land in Missouri).

427 Allen, supra note 17, at 12-13.

428 See Homestead Act of 1862, ch. 75, 12 Stat. 392 (vesting title to certain land in those people who established that "they ha[d] resided upon or cultivated the same for [a] term of five years").

${ }^{429}$ Allen, supra note 17 , at 5 . 
for land: in order to establish title, settlers make investments in improvements before the market dictates that such expenditures are warranted. $^{430}$ Allen has persuasively argued, however, that enforcing property rights against the Indians was the positive external effect that justified preemption, homesteading, and other subsidies.

U.S. public land policies of the nineteenth century were appropriate in light of the costs of enforcing property rights. Due to the Indian's simultaneous claim on public lands and the costs imposed by this dispute over property rights, the land policies were efforts to "hire" settlers to reduce the costs of enforcement. The state may have a comparative advantage in enforcing property rights through violence; however, when disputes occur, the state will use a least-cost strategy to secure ownership. In this light, homesteading is a substitute for direct military force and acts to mitigate the costs of violence. ${ }^{431}$

Preemption and homesteading established a large population on a given piece of the frontier. Settlers presented the Indians with a large local militia that made the odds of a victorious attack so low that, realizing their weakness, the tribes sold out cheaply. ${ }^{432}$

However opposed the common law tradition might be to squatters, these settlers played an important role in expropriating Indian lands at minimal cost. ${ }^{43}$ Even during colonial times, the usefulness of squatters in helping to eliminate Indian land claims was too powerful to ignore. Massachusetts, while eliminating Indian tribes from the western part of the state, found ousting squatters difficult, inter alia, "because of the usefulness of the squatters in this area as a buffer." The British government defended actual settlers against holders of later-issued warrants for lands in New Hampshire grants because "[i]t

${ }^{430}$ See Terry L. Anderson \& Peter J. Hill, The Race for Property Rights, 33 J.L. \& ECON. 177, 191 (1990) (noting that "speculators... would hold [land] out of production ... with no apparent settlement activity, while squatters and homesteaders would engage in premature development of the land," and that "[i]t was the speculators who took socially efficient action by not doing anything on the land").

431 Allen, supra note 17 , at 2 . Allen seems to hint at the equally important effect of spreading disease and thinning game: "[t]he sudden arrival of tens of thousands of people into a given territory destroyed much of the Indian way of life." Id. at 5-6.

${ }^{432}$ For an incredibly detailed account of the incessant pressure that early settlers placed on the tribes along the Ohio River from 1768 until the national army dispersed remaining resistance in the Battle of Fallen Timbers in 1794, see AILAN W. ECKERT, THAT DARK AND BLOODY RIVER, GHRONICLES OF THE OHIO RIVER VALLEY (1995).

${ }^{435}$ Note that in relatively crowded England, squatting served no socially useful purpose. The common law of trespass is presumably efficient under a well-developed property regime, since it forces all interested parties to negotiate with owners to use land, resulting in allocation to the highest value user.

${ }^{434}$ KAWASHIMA, supra note 33, at 68. 
was felt that the difficulties of early settlement on lands exposed to the incursions of the savages and French made it imperative in justice and equity that the original proprietors should be quieted in their possessions." 435

After the Revolutionary War, state and federal governments often showed the same predisposition in favor of squatters. Tennessee's original Bill of Rights, for instance, created a right of preemption based on the dangers weathered, and services rendered, by the earliest settlers. ${ }^{436}$ Local federal officials warned their superiors in Washington that the perceived injustice of ousting squatters was so strong that soldiers simply would not obey orders to that effect.

At this time it is my opinion, justified by the statements of many, that five militia men of this Territory would not march against the intruders on public lands.... Much feeling has been excited on this subject, as those who may be found on public lands are the persons who have borne the storm of the Indian War, being on the frontier.

As discussed in the following section, the government made infrequent and largely ineffective attempts to remove squatters, especially those on Indian lands. ${ }^{439}$ Roback contrasts this failure to enforce the law with the zealous enforcement of the M'Intosh rule against private purchases from the Indians: "The government indirectly subsidized white intrusions onto Indian lands by enforcing the prohibition on land sales more effectively than they enforced the prohibition on squatting." "\$39

Not only did the government refuse to remove squatters from Indian land, but it also invariably protected them wherever they hap-

${ }^{435}$ FORD, supra note 364, at 128.

${ }^{436}$ REMINI, supra note 207, at 78 ("The Bill of Rights ... stated that the people who had pioneered this country ... were entitled to the right of preemption and occupancy, [and that] because these settlers had lived in the region without benefit of land and exposed to pillage, starvation, and massacre, it was felt that preemption was richly deserved.").

${ }^{437}$ ROHRBOUGH, supra note 96, at 61-62 (quoting Letter from St. Louis Land Register McNair to General Land Office Commissioner Tiffin) (footnote omitted). While this and the preceding quotes speak of doing justice ex post by granting title to squatters, the more important effect of legal rules is the incentives they create for future behavior.

${ }^{438}$ See infra Part II.E.2 (discussing negative externalities of lawless settlers, speculators, and traders).

${ }^{439}$ Roback, supra note 190 , at 20 . She goes on to note that this may have been true in part because the cost of preventing squatting was quite high, while the cost of enforcing the M'Intosh rule was low. See supra notes 190-92 and accompanying text (noting how "the rule of $M$ 'Intosh solved a collective action problem and permitted the nation to avoid expensive bidding wars for Indian lands"). 
pened to settle. There is a nagging question here: why protect squatters on Indian lands? As discussed at length in the next section, such squatters provoked innumerable acts of retribution from Indians protecting their land, and these sometimes lethal retaliations often fell on legal settlers, travelers, and others not guilty of any provocation. ${ }^{440}$ The point here is that the seemingly obvious way to deal with squatters on Indian lands would have been to leave them at the mercy of the Indians.

The United States may have rejected such a hard line due to concerns about its reputation. In order to attract settlers to drive the engine of efficient expropriation, be they squatters or legal buyers, the nation needed to establish a strong reputation as a protector of those on the frontier. Although officials in a world of perfect information could have treated illegal squatters differently than legal buyers, in an environment of slow communication over great distances, from an ever-evolving frontier, it may have been impossible to pursue such a nuanced policy. If the United States wished to attract occupants to its millions of western acres, it first and foremost needed to reassure potential settlers that the government would always, and to the utmost of its ability, protect them from Indian violence-even when they provoked it.

\section{Negative Externalities of Lawless Settlers, Speculators, and Traders}

Unfortunately, egregious conduct by frontiersmen was frequent. The most problematic practice was squatting on Indian lands, coupled with acts of violence against tribe members. "The greatest menace to the stability of the frontier was often the aggressive, undisciplined settler himself. He regarded the Indian as an animal to be exterminated ...."411 This was a longstanding problem; in the 1670 s, the governor of colonial Virginia worried that frontiersmen "might well provoke an Amerindian war in order to secure land and slaves, thus drawing the whole colony into the human and fiscal consequences. ${ }^{\text {,412 }}$

By provoking hostilities that bled over and affected neighbors and those further from the frontier, frontiersmen whose activities created positive external benefits also created negative external costs. When

${ }^{440}$ See infra Part II.E.2 (describing frequent conflicts between squatters and natives).

441 Sosin, supra note 225 , at 82.

442 STEELE, supra note 204, at 53; see also ABERNETHY, supra note 67, at 107 ("Tidewater Virginians in general had little interest in Indian wars. They knew the cost to them would much outweigh any immediate benefits."). 
settlers provoked Indians, the negative external effects of Indian retaliation were far-reaching, endangering Europeans for miles in every direction. Since frontier squatting often enabled settlers to obtain valuable land, it may have been rational from an individual settler's point of view. However, Indian retaliation hurt others. Therefore, in the social calculus, squatting on Indian lands and instigating bloodshed often did more harm than good. ${ }^{443}$

Costs imposed on society by lawless squatters infuriated both government officials and citizens removed from the frontier. According to one British general, "[a]ll the settlers on the frontier were not worth what a campaign against the Indians would cost. ${ }^{\text {444 }}$ Thomas Jefferson declared:

[T] he U.S. [will] find an Indian war too serious a thing, to risk incurring one merely to gratify a few intruders with settlements which are to cost the other inhabitants of the U.S. a thousand times their value in taxes for carrying on the war they produce. I am satisfied it will ever be preferred to send [ing] armed forces and mak [ing] war against the intruders as being more just \& less expensive.

There was a "general Eastern conviction that the frontier was a terrible place inhabited by terrible people whose main business in life was stirring up Indian wars for which Easterners had to pay. ${ }^{346}$ One official argued that "he who preserves Peace with Indians thereby serves the Indians [,] but it is equally true that by that act he in a much greater degree serves his Fellow Citizens."

The federal government enacted a series of Trade and Intercourse Acts to rein in frontiersmen engaging in provocative behavior. ${ }^{448}$ In addition to codifying and nationalizing the rule against pri-

443 See Anderson \& McChesney, supra note 16, at 50 (describing adherence to treaties as a version of the prisoners' dilemma and noting that "[e]ven if the total benefits from a treaty exceed its total costs for both sides, any particular individual may find it in his interest to violate the treaty terms").

${ }^{444}$ WHITE, supra note 62 , at 362 (footnote omitted).

${ }^{415}$ PRUCHA, supra note 6, at 139 (quoting Letter from Thomas Jefferson to David Campbell (Mar. 27, 1792)).

446 ABERNETHY, supra note 67, at 73. As discussed in Part II.E.1.b, Easterners could not refuse to help in fights provoked by squatting and violence if they hoped to maintain the protective reputation necessary to attract settlers to the nation's extensive frontier lands.

${ }^{447}$ Letter from Governor William Blount to Alexander Kelley and Littlepage Sims (Dec. 1, 1795), reprinted in 4 TERRITORIAL PAPERS, supra note 31, at 408, 410 (1936).

${ }^{448}$ Congress enacted the first Trade and Intercourse Act in 1790, see Trade and Intercourse Act of 1790, ch. 33, 1 Stat. 137, and amended the law frequently through the mid-1800s. See generally PRUCHA, supra note 205, at 100-04 (describing the U.S. gov- 
vate purchases of Indian lands, these acts regulated a number of sensitive areas of conflict, including crime between Indians and Americans, trade (particularly in liquor and fur), and removal of squatters from Indian lands. ${ }^{449}$

Astute frontiersmen realized the government's concern and promised to avoid creating negative external effects that would impose costs on the rest of the nation. In petitioning the federal government for land grants, for instance, plaintiff William McIntosh and others emphasized that they were intent on "preserving and securing the Friendly Intercourse and Harmony which at present happily subsists between them and those Indian Tribes" and carefully limited their requests to "places within the limits of the Indian cessions."

The government took measures aimed at restraining the more severe negative external effects created by lawless squatters. In the words of Merriwether Lewis, " $[t]$ he first principle of governing the Indians is to govern the whites." ${ }^{\text {"51 }}$ Many colonial treaties paid damages to survivors of Indians wrongfully killed. These provisions were "designed to forestall escalating violence between individuals, which might result in war. ${ }^{452}$ Preventing a violent backlash due to squatting was one of the primary motivations for the Proclamation of 1763 and similar laws precursing the M'Intosh decision. ${ }^{153}$

Chief Justice Marshall adverted to such policies in M'Intosh, noting efforts made so that the tribes' "friendship should be secured by quieting their alarms for their property. This was to be effected by restraining the encroachments of the whites. ${ }^{954}$ Pelatiah Webster, otherwise sympathetic to law-abiding frontiersmen, had little patience with those squatting on Indian lands and provoking conflict: "For it is un[r] easonable that the public tranquillity [sic] [s] hould be endan-

ernment's Indian policy as expressed in the Trade and Intercourse Acts).

${ }_{449}$ See, e.g., Trade and Intercourse Act of 1790, supra note 448 (requiring all citizens who trade with Indians to carry a federal license and codifying treatment of citizens who commit crimes on Indian lands).

${ }^{450}$ Petition to Congress by Inhabilants of Knox, St. Clair, and Randolph Counties [Indiana Territory] (Oct. 22, 1803), reprinted in 7 TERRITORIAL PAPERS, supra note 31, at 125, 127 (1939).

${ }^{451}$ PRUCHA, supra note 261, at 75 (quoting 7 ORIGINAL JOURNALS OF THE LEWIS AND CLARK EXPEDITION, 1804-1806, at 378, $387-88$ (Reuben Gold Thwaites ed., Antiquarian Press Ltd. 1959) (1904-05).

${ }_{152}$ LARRY C. SKOGEN, INDIAN DEPREDATION ClAAMS, 1796-1920, at 19 (1996).

453 The desire to ensure good relations with the Indians motivated a 1779 Virginia ban on settlement north of the Ohio River. See GATES, supra note 64, at 39 (explaining the Virginia Legislature's dual concerns of protecting the rights of squatters and maintaining good relations with the Indians).

${ }^{454}$ Johnson v. M'Intosh, 21 U.S. (8 Wheat.) 543, 597 (1823). 
gered for the [s]ake of the convenience of a few people, who, without the lea[s]t pretence of right, have fixed them[s]elves down on lands not their own."

The government made sporadic efforts to remove squatters forcibly from Indian land in order to minimize retaliatory attacks. ${ }^{46}$ William Murray, the driving force behind the Illinois and Wabash land Companies, may have participated in such an effort while serving in the King's army at Pittsburgh in $1766 .^{457}$ Removal, however, was expensive and ineffective. Neither the colonies nor the United States was willing to maintain enough troops to monitor a frontier hundreds of miles long. ${ }^{458}$ In the absence of a permanent police force, settlers returned a few days after the troops left. If their crops were destroyed and their homes demolished, they simply replanted and rebuilt. ${ }^{459}$

Potentially effective alternatives existed. Andrew Jackson, for instance, proposed that troops seize the squatters' cattle, horses, and other valuable animals. Because animals were the predominant form of personal wealth, such a policy might well have deterred squatters. The War Department, however, would not adopt such a harsh policy. ${ }^{460}$ As discussed in the previous Part, the government seemed to

455 WEBSTER, supra note 297 , at 495.

${ }^{456}$ In 1745 , Pennsylvania ejected settlers, destroyed their improvements, and even bought land for some "in order to quiet the Indians," but "[i]n defiance of this, men persisted in occupying the ground as boldly as they had always done." FORD, supra note 364, at 115. Pennsylvania and Virginia took similar measures in the 1760s. See VOLWILER, supra note 312, at 218-19 (detailing Pennsylvania's repeated attempts to oust squatters from Fort Pitt); Jack M. Sosin, Brilain and the Ohio Valley 1760-1775: The Search for Allernatives in a Revolutionary Era, in CONTEST FOR EMPIRE, supra note 287, at 61, 63-64 (discussing failed efforts by the governors of Pennsylvania and Virginia to remove squatters). General Harmar removed Ohio Valley squatters in 1785; some returned even after the army destroyed their improvements three times. The general told George Washington the effort was hopeless. Despite this abysmal record, the United States repeatedly tried to remove squatters from Cherokee lands in 1809 . See PRUCHA, supra note 6, at 159-60 (describing removal of squatters in response to Chickasaws' threat to burn their houses and squatters' subsequent resettlement, necessitating further action).

${ }^{457}$ See Marks, supra note 50, at 191 (describing orders Murray received to remove homesteaders at Red Stone Creek).

${ }^{458}$ See PRUCHA, supra note 6, at 165 ("A serious weakness in the protection of the Indian Country was the peacetime shortage of troops to enforce the removal of intruders.").

${ }^{459}$ See id. at 164 (noting that destruction of settlers' improvements and removal of cattle failed to prevent squatters from returning several days later).

${ }^{460}$ See Letter from George Graham, Acting Secretary of War, to Major General Andrew Jackson (Aug. 14, 1817), reprinted in 18 TERRITORIAL PAPERS, supra note 31, at 135-36 (1952) (asserting that the federal government had no jurisdiction to seize stock belonging to the squatters). 
have been concerned with preserving its reputation as a reliable guardian. After all, the nation could not hope to attract wave after wave of land purchasers without a reputation for protecting all frontier settlers. This also explains why, despite the great cost of Indian wars, colonists in less exposed regions had little choice but to finish the conflagrations begun by their frontier cousins.

Instead of punishing rogue settlers, the government borrowed a colonial practice of paying damages to aggrieved Indians in order to limit the external effects of lawless settlers. This approach made economic sense and maintained the government's reputation for protecting its citizens. As Prucha noted:

[The United States] frequently resorted to compensating the families of murdered Indians by payment of a fixed sum of money or goods.... A sum of one to two hundred dollars for each Indian murdered by whites was suggested by the secretary of war in 1803, and this amount was regularly given.

... By providing machinery for recovery of losses by peaceful means, it eliminated any justification for private retaliation and was largely successful in removing this friction....

Paying damages was an ex post remedy, made necessary by the nation's difficulty controlling trespasses on Indian land and the inevitable violence that followed.

Even though the United States had tried to bring some order into the western advance by organizing repeated cessions and creating boundary lines which for the time being were supposed to be inviolate, the government was never able to stem the illegal advance. Settlers crossed the boundary line to obtain choice lands, and the government never mustered sufficient military force to prevent the intrusions. ${ }^{462}$

Roback notes:

$[\mathrm{H}]$ ow little sovereignty the 'Sovereign' actually had over his subjects. The English colonists were themselves sovereign individuals.... The English Americans made choices subject to the constraints placed on them by their own rulers and by the Indians. In many cases, the laws were so costly to enforce that they amounted to only a minimal constraint on the behavior of individual settlers. ${ }^{463}$

${ }^{461}$ PRUCHA, supra note 261, at 106-07. The government also compensated whites for thefts by Indians, to discourage 'self-help' private retaliation that might have engendered retaliatory Indian violence.

${ }^{462}$ HORSMAN, supra note 90, at 160.

${ }^{463}$ Roback, supra note 190, at 13-14. 
Mocking George Washington's laments about the difficulty of controlling frontiersmen, Limerick archly noted that "[r]ather than the government controlling the people, the people-or at least those on the far fringes of settlement-had the power to control the government, which is what, after all, democracy is supposed to mean. ${ }^{464}$

Democracy, however, is a bit more complicated. As discussed above, the nation was dealing with a collective action problem: while it was in an individual settler's interest to trespass on Indian lands and perhaps commit acts of violence, every American would benefit if officials could restrain settlers. ${ }^{465}$ This would allow the nation to rely on the more orderly and less expensive tools of disease, game-thinning, and negotiating advantages to combat Indians, rather than the expensive tool of violence.

In addition, American democracy was capable of solving, at least in part, this collective action problem. It is easy to overstate the powerlessness of the United States to control activity on the frontier. Moreover, the positive externalities created by squatters diluted the government's desire to control them.

The federal government was sincerely interested in preventing settlement on Indian lands only up to a point .... The basic policy of the United States intended that white settlement should advance and the Indians withdraw. Its interest was primarily that this process should be as free of disorder and injustice as possible.... It supported Indian claims as far as it could out of justice and humanity to the Indians and above all as far as it was necessary to keep a semblance of peace and to maintain Indian good will so that continuing cessions of land could be evoked from the tribes. ${ }^{466}$

Summing up the effects of the Trade \& Intercourse Acts, Prucha finds that "if the goal was an orderly advance, it was nevertheless advance of the frontier." (for example, granting title only to those on lands purchased by the nation) and the stick (for example, occasionally removing settlers from Indian land, at least temporarily) was able to mitigate some of the squatters' negative external effects that most threatened the public interest.

The relative effectiveness of American regulation of frontiersmen

${ }^{464}$ LIMERICK, supra note 345, at 192.

${ }^{465}$ See supra text accompanying note 443 . (describing the prisoner's dilemma frontier settlers faced).

${ }_{466}$ PRUCHA, supra note 6, at 186-87 (emphasis added).

${ }^{467}$ Id. at 3. 
contrasts sharply with the tribes' complete inability to police their members, especially young warriors bent on punishing the trespasses and murders committed by settlers. ${ }^{463}$ Roback argues that the tribes, long unsuccessful in regulating citizens in a forest environment, did not really try to control members by fiat (majority or otherwise), but relied instead on unanimous consent. ${ }^{49}$ Roback's theory again highlights the Indians' significant bureaucratic disadvantage. The repercussions for the tribes of young warriors' aggression were much more severe than for the Americans, yet the Indians could not police their own members at all. In contrast, although the United States could not control the forested, sparsely-populated frontier as well as it could control life in Boston or Philadelphia, its extensive bureaucracy could limit activities imposing costs on the rest of the nation.

The history of the M'Intosh rule as applied against private purchases shows that European governments, based on a developed bureaucratic legal system, could effectively regulate at least some socially undesirable behavior effectively. Land speculators, like squatters, often fomented Indian hostilities. "An avaricious disposition in some of our people to acquire large tracts of land and often by unfair means, appears to be the principle source of difficulties with the Indians.",770 South Carolina's colonial legislature cited Indian policy as the motivation for passing legislation banning private purchases:

[T] he practice of purchasing lands from the Indians may prove of very dangerous consequence to the peace and safety of this Province, such purchases being generally obtained from Indians by unfair representations, fraud and circumvention, or by making them gifts or presents of little value, by which practices, great resentments and animosities have been created amongst the Indians towards the inhabitants of this Province. $^{47 t}$

When Great Britain took over all Indian affairs in the Proclamation of 1763, it echoed these concerns about speculators' purchases from the tribes: "[G]reat frauds and abuses have been committed in the purchasing lands of the Indians, to the great prejudice of our in-

${ }^{469}$ See SKOGEN, supra note 452 , at 20 ("One of the seemingly omnipresent features of Indian-white councils has been the repeated admission by Indian leaders that they could not control their young men.").

${ }^{469}$ See Roback, supra note 190, at 14-16 (examining political organization of the Iroquois at both the village and tribal levels).

${ }^{270}$ HORSMAN, supra note 90, at 40 (quoting 33 JOURNALS OF THE CONTINENTAL CONGRESS, 1774-1789, at 454, 457 (Roscoe R. Hill ed., 1936)).

4713 The STATUTES AT LARGE OF SOUTH CAROLINA, supra note 46, at 525, 525. 
terest, and to the great dissatisfaction of the said Indians." ${ }^{472}$ When William Murray purchased the Illinois Company's lands in 1773, British officials "feared that settlements which were rumored to be made in the spring by emigrants from the East would irritate the Indians" and disrupt the peace. ${ }^{473}$ These concerns led to a proclamation in 1774 reaffirming the policy against private purchases of Indian lands. ${ }^{47}$ Other large prerevolutionary land speculation schemes raised the same concerns. ${ }^{475}$ The New York Constitution of 1777 justified its ban on private purchases on the "great importance of this state, that peace and amity with the Indians within the same, be at all times supported and maintained; and that the frauds too often practised towards the Indians, in contracts made for their lands, had, in divers[e] instances, been productive of dangerous discontents and animosities." ${ }^{476}$

The same divergence between individual and societal costs that drove squatter activity also drove speculators to buy land despite probable adverse consequences to others.

Land speculators were unconcerned that their actions aroused the tribes and could lead to another bloody Indian war.... Since the lands between the mountains and the Ohio were said to be so extremely fertile, "people will run all risques [sic] whether from Governments or from Indians" to settle there "without the least plea of Right.,"77

As Roback observes, "a fraudulent transaction with the Indians could have substantial spillover effects on other colonists if the Indi-

${ }^{472}$ GATES, supra note 64, at 34 (citation omitted).

${ }^{473}$ Marks, supra note 50, at 202 (summarizing a letter from General Haldimand to Dartmouth, Secretary of State (Nov. 3, 1773)); see also JACK M. SOSIN, WHITEHAIL \& THE WIIDERNESS: THE MIDDLE WEST IN BRITISH COLONIAL POLICY, 1760-1775, at 233 (1961).

${ }^{474}$ On March 10, 1774, General Haldimand issued a proclamation prohibiting the private purchase of land from the Indians. See SosIN, supra note 473, at 233 (describing the aftermath of Murray's land purchases).

${ }^{475}$ In explaining the delay in approving the Vandalia scheme (founded on an Indian deed to a large tract of land in Ohio, West Virginia, and Indiana) officials declared that " $[t]$ he government was also much concerned over the unlicensed emigrations into the interior parts of America. It was feared that this movement westward would likely lead to an Indian war, which would prove detrimental to the older colonies and expensive to the crown." LEWI, supra note 65, at 126 (citing extracts from PA. GHRONICIE, June 7, 1773).

${ }^{476}$ N.Y. CONST. of 1777 , art. 37 ("[N]o purchases or contracts for the sale of lands, made with, or of the said Indians, shall be binding on them, or deemed valid, unless made under the authority and with the consent of the legislature.").

${ }^{477}$ SOSIN, supra note 473 , at 122-23 (quoting Letter from Virginia Lieutenant Governor Fauquier to Shelburne, Head of British Board of Trade (Dec. 18, 1766)). 
ans chose to make reprisals more or less at random. ${ }^{478}$ Speculators were much less likely than even squatters to suffer at the hands of Indians who felt cheated or betrayed by their leaders. How likely was it that a merchant member of the United Illinois and Wabash Companies, sitting in a Philadelphia counting house, would suffer at the hands of angry young warriors?

The long line of statutes, proclamations, and court decisions barring private purchases, culminating in M'Intosh, eventually curbed such purchases. There were few, if any, attempts by private groups to purchase Indian lands after the Revolution. This policy both reduced Europeans' actions that provoked Indians to violence, and helped maintain a united front in the purchase of Indian lands. ${ }^{479}$ The Indian tribes, on the other hand, lacked the governmental structure to regulate their members' activities. Their closest equivalents to speculators were perhaps the tribal chiefs who sold them land, claiming to represent entire tribes. Members found it difficult to regulate chiefs who, acting as disloyal agents, took bribes in return for selling tribal lands at fire-sale prices. ${ }^{480}$

\section{Positive Externalities of Trade}

In addition to small-scale squatters and large-scale land speculators, Europeans trading in personal property defrauded the Indians and provoked violent reprisals against others.

Fraud and illegal practices on the part of traders stirred up Indian indignation and anger and thus led to frequent retaliations against the white community. In an attempt to prevent abuses, multifarious legislation regulating the conditions of the trade was enacted.... Because the Indian trade had such close bearing on the public welfare, the colonial governments insisted on strict measures of control. ${ }^{181}$

478 Roback, supra note 190, at 12.

479 See supra Part II.B (describing the governing of European-Indian relations and the creation of a united front among European sovereigns).

${ }^{480}$ See supra Part II.B.2.c.

481 PRUCFA, supra note 261, at 18-19. Europeans feared negative external effects of trading arms and liquor with the Indians. Guns made the Indians much more formidable military foes; drunkenness often resulted in random acts of violence. "At times the Massachusetts government, like those in other colonies, prohibited the sale of certain articles to the natives to ensure colonial security and peace.... Conspicuous among such commodities were firearms and alcohol." KAWASHIMA, supra note 33, at 79. The United States enacted similar provisions in the Trade and Intercourse Acts. See PRUCHA, supra note 261, at 19 (describing restrictions on sales of arms and rum to Indians). 
These problems in part motivated the Trade and Intercourse Acts. Fair trade, however, had significant positive externalities. Tribes dependent upon European settlers for a host of necessities (such as guns for tribes that had lost the art of making and using bows, or metal pots and pans for tribes that had lost the art of making pottery) were much less likely to resist European pressure for land. This explains, for instance, why Massachusetts subsidized the Indian trade long after it had become unprofitable: "The Indians were no longer valuable customers, and truck trading cost the colony large sums of money, although not nearly so much as was expended in Indian wars." ${ }^{\text {482 }}$ United States officials took a similar view and advocated trade as a way "to conciliate the affections of a distressed and unhappy people, and as it might prevent the expense of a war with them .... It was clear as a sunbeam, one representative remarked, that the establishment of a trade must be the foundation of amity." 483

President Jefferson defended federally financed trading houses, despite the losses they generated, because trade was "the cheapest \& most effectual instrument we can use for preserving the friendship of the Indians." A84 A decade later, an official counseled the Senate against worrying about financial problems in the Indian trade "factories" run by the federal government. The justification for the system, he said, "must be found in the influence which it gives the Government over the Indian tribes within our limits .... The most obvious effect of that influence is the preservation of peace with them, and among themselves." 485

\section{F. Putting the Pieces Together: The Algorithm of Efficient Expropriation}

By a repeated process of drawing on natural allies and providing

These laws, however, did not work. Indians obtained arms and liquor from settlers willing to risk breaking the law to earn high profits, or from agents of other nations competing for the Indians' trade and military assistance. See KAWASHIMA, supra note 33 , at 82 (noting that "[a]s long as the colonists wanted fur from them ... the Indians had no difficulty in securing liquor and firearms, with or without legal permission"); Anderson \& McChesney, supra note 16, at 60 (noting that "Indians usually were able to obtain new weapons ... almost as soon as they were available to whites"). The high costs of enforcing even a limited trade embargo meant that this collective action problem was unsolvable.

${ }^{482}$ KAWASHIMA, supra note 33, at 90-91 (internal quotations and citation omitted).

189 PRUCHA, supra note 261, at 116 (quotations and citation omitted).

484 Letter from President Jefferson to Secretary of War Dearborn (Aug. 12, 1802), reprinted in 7 TERRITORIAL PAPERS, supra note 31, at 68 (1939).

${ }_{485}$ PRUCHA, supra note 261, at 127 (quotations and citation omitted). 
them with legal rules to encourage socially useful acts (those with positive external effects) and to discourage socially harmful acts (those with negative external effects), the Europeans managed to expropriate Indian lands very cheaply.

The process, broken down into components of a repeated "loop," looks almost like a computer program:

Step (1): exploiting its more united front, its military superiority, its negotiating advantages, its superior ability to rein in troublemakers, and the trade dependency of the tribes, the United States buys Indian borderlands for pennies on the dollar;

Step (2): the nation then moves settlements into the lands purchased from the Indians, and spurs migration with subsidized land transfers;

Step (3): these settlers kill Indians by spreading diseases and thin game by clearing land and hunting-both making land less valuable to the Indians;

Step (4): go to Step (1) and repeat the process.

\section{G. Analogizing Efficient Conquest to Eminent Domain}

This Article posits that, more than anything else, cost minimization explains the laws and policies employed by the United States to expropriate Indian lands. This expropriation was a gargantuan project, so it is not surprising that the United States employed a wide variety of means to achieve this end. Before concluding, it is interesting and enlightening to consider how the United States would have achieved the same ends if its citizens owned the coveted acreage.

Assume that, instead of Indians, a relatively small group of mountain men owned "the west" and wished to maintain their preagricultural way of life in the face of encroaching civilization. There is no question that the United States could, and likely would, have employed the power of eminent domain to take frontier lands, paying the constitutionally required just compensation. In computing this just compensation, moreover, the courts would not weigh any sentimental (subjective) value that the frontier population attached to their way of life. ${ }^{486}$ They would instead pay the value of the land in its

${ }^{486}$ See 3 Nichols on EMINENT DOMAIN \$ 8.07 (Julius L. Sackman ed., rev. 3d ed. 1999) (discussing the just compensation to which an owner is entitled in terms of economic loss sustained by the owner). But $c f$. Jack L. Knetsch \& Thomas E. Borcherding, Expropriation of Private Property and the Basis for Compensation, 29 U. TORONTO L.J. 237 
highest and best use, excluding the increment in value due to the governmentally supervised project of bringing the land under cultivation and intense settlement. ${ }^{487}$ The frontiersmen would no doubt find such compensation incomplete, yet to award them more would amount to forcing society to share the gains from the land's highervalue use with the frontiersman. Governments have the power of eminent domain precisely in order to avoid such windfalls to owners of assets of significant public value. ${ }^{488}$

Now substitute the Indians for the frontiersmen. In the eyes of the European colonizers, the Indians were underutilizing a continent. By converting the economy from hunting and gathering to agriculture and industry, the United States and its predecessors knew that they could create much more wealth-as they defined the term. ${ }^{489}$ Thus, the same thinking that justifies eminent domain may also have made Americans comfortable with all the devices employed to obtain Indian lands cheaply. They saw no reason to share the gains, due to introducing agriculture and a more technologically advanced society, with the relatively few existing owners unable to put the land to such higher-value uses.

There is no doubt that, from the Americans' perspective, expropriating land and selling it to settlers was a very profitable enterprise. The United States usually paid less than two cents an acre for land east of the Mississippi. ${ }^{490}$ This fell far below the value of the land to the na-

(1979) (noting the possible inefficiency of failing to pay owners for their subjective (above-market) valuation of their property).

${ }^{487}$ When considering just compensation where property is taken by eminent domain,

[t] he general rule forbids consideration of the effect of the proposed project upon the value of the property taken. If, however, the present adaptability of such property for the projected use is a determinative factor in creating a special demand for such property..., it does have a real and substantial effect upon its market value....

3 NICHOLS ON EMINENT DOMAIN, supra note $486, \S 8.07$.

${ }^{488}$ See Eric Kades, Avoiding Takings "Accidents": A Tort Perspective on Takings Law, 28 U. RICH. L. REv. 1235, 1254 (1994) (discussing how the government's power of eminenet domain stops a land owner from holding out for the additional land value created by the planned government project).

${ }^{489}$ See supra Part I.A (summarizing colonists' assertions that agricultural societies had rights to land superior to those of hunter-gatherer groups). Thomas Flanagan interprets the colonists' argument as a form of eminent domain, as long as transferring the land from Indians to Europeans was Pareto efficient. See Thomas Flanagan, The Agricultural Argument and Original Appropriation: Indian Lands and Political Philosophy, 22 CAN. J. POL. SCI. 589, 596-99 (1989).

${ }^{490}$ See PRUCHA, supra note 205, at 122-25 (citing instances when land was purchased for less than two cents per acre); 7 TERRIORIAL PAPERS, supra note 31, at 256- 
tion and its land-hungry settlers. Lewis Cass advised the Secretary of War in 1817 not to quibble too much about the details of land cessions from the Indians, since " $[u]$ nder any circumstances, [the consideration we pay] will fall infinitely short of the pecuniary and political value of the country obtained." ${ }^{\text {"91 }}$

All the time that "the United States had been refusing to pay the Indians more than two cents an acre for even the best land... the government charged its own western settlers two dollars an acre., ${ }^{, 92}$ While the record is spotty, there is strong evidence that administrative and transaction costs consumed only a small portion of this $\$ 1.98$ spread.

Expenses incurred by the national government till the War of 1812 for surveying, officials' salaries, and boards of commissioners [in Indiana] were about $\$ 90,000$. This amount was approximately equal to the sales during the first five months at the Vincennes land office alone. In fact, sales at either of the two Indiana offices for five years beginning in 1812 were greater than all governmental expenditures made for preparing and offering lands from 1789 to the middle of the [War of 1812].

Recasting expropriation as an analog of eminent domain reinforces one of the rationales for the M'Intosh decision: preventing speculators from reaping part of the gains from expropriation that came about in large part because of the combined power of all Americans, organized by their government. Just as the M'Intosh decision

57, 301-03 (1939) (providing letters indicating the same); Letter from Secretary of War Dearborn to Charles Jouett (1805), reprinted in AMERICAN STATE PAPERS, supra note 81, 1 INDIAN AFFAIRS 702-03 (1832) (stating that " $t$ the price usually given for Indian cessions ... has not exceeded one cent per acre"); Smith, supra note 37, at 230 (recounting how between two and three million acres of land were sold for less than two cents per acre).

${ }^{491}$ Letter from Governor Cass to Acting Secretary of War Graham (Apr. 17, 1817), reprinled in AMERICAN STATE PAPERS, supra note 81, 2 INDIAN AFFAIRS 136, 136.

${ }_{492}$ HORSMAN, supra note 90, at 130-31 (discussing the American purchase of Creeks lands around 1805). While the United States did not always obtain the statutory reservation price of two dollars an acre, for many choice tracts it obtained considerably more. On average, two dollars an acre is a lower bound on the price the United States received for acres sold to settlers. See TrHomas DONALDSON, TrEE PUBLIC DOMAIN: ITS HISTORY, WITH STATISTICs 203 tbl., 520-21 fold-out tbl., 522-23 fold-out tbl. (1884) (providing statistics on Indian land sales that indicate prices of at least two dollars per acre); GATES, supra note 64, at 132 tbl., 133 tbl. (providing data regarding collections and average prices on sold lands).

${ }^{493}$ Bayard, supra note 220, at 266 (citing 8 TERRITORIAL PAPERS, supra note 31, at 362 (1939)); see also ADAM SEYBERT, STATISTICAL ANNALS 367-68 (Ben Franklin Press 1969) (1818) (providing summary statements regarding sales of land from 1812 to 1817); Expense of Surveying and Selling the Public Lands, and of Ascertaining Titles to Private Claims (Feb. 26, 1813), reprinted in AMERICAN STATE PAPERS, supra note 81, 2 PUBLIC LANDS 739. 
denied speculators the value derived from the efforts of others in a society-wide project, in eminent domain law, landowners receive no portion of the higher value that will result from the government's planned use. ${ }^{494}$

The nation did not invoke eminent domain against the Indians because it could not: they did not recognize the power of the United States unilaterally to oust them and decide the fair value of their land. This subsection argues that all the techniques used to expropriate Indian lands, taken together, were an alternative process to effectively condemn Indian lands in exchange for compensation deemed fair by the United States. The Indians, in the end, were treated no differently than landowners who refuse to leave their property despite the promise or actual payment of just compensation; they were forcibly removed if necessary and payment was still made.

Ultimately, as their ability to resist dissipated, payments to Indians for their land came to look almost exactly like just compensation. While later judicial decisions permitted the government to take land without paying compensation, ${ }^{495}$ but by statute or executive decision, the United States continued to pay for expropriated Indian lands. ${ }^{496}$

${ }^{494}$ See supra notes $486-88$ and accompanying text (providing sources that support and explain this principle of eminent domain law).

495 See Lone Wolf v. Hitchcock, 187 U.S. 553 (1903) (holding that the United States may unilaterally abrogate treaties with tribes, and thus take away property rights guaranteed to the tribes under treaty); Tee-Hit-Ton Indians v. United States, 348 U.S. 965 (1955) (holding that tribes had no constitutional right to just compensation for expropriation of their title of occupancy). As noted, Tee-Hit-Ton, along with Lone Wolf, seem inconsistent with $M$ 'Inlosh, which defended Indian title against outright seizure except in the case of a just (defensive) war. If, as this Article argues, the basis for the holding in M'Intosh is custom, there is no reason that later cases cannot modify the rule to account for changed circumstances. Where a weaker nation prior to 1823 sacrificed nothing by conceding that it was legally required to pay for what it could not take cheaply, a more developed, powerful nation (especially after the Civil War) could seize land more cheaply and found no value in the portion of the M'Intosh rule that forbade outright seizure. Moreover, despite the rule enunciated in Lone Wolf, the United States continued to pay for Indian land in almost every case (even after wars of conquest). See supra notes 3-7 and accompanying text (describing instances where the U.S. government purchased land, even after Lone Wolf). The United States did so for the same reason it always had before: fighting involves deadweight loss and negotiated settlements offer gains from trade for both sides. See supra Part II.C (discussing the advantages of negotiated settlement over fighting).

${ }_{496}$ "Starting with the Rosebud Act in February 1904, individual statutes opened reservations to taking at congressionally set prices, rather than prices negotiated with the Indian owners." Fred S. McChesney, Government as Definer of Property Rights: Indian Lands, Elhnic Externalities, and Bureauctatic Budgels, 19 J. LEGAL STUD. 297, 313 n.57 (1990) (citing FREDERICK E. HOXIE, A FINAL PROMISE: THE CAMPAIGN TO ASSIMILATE INDIANS, 1880-1920, at 157 (1984)). While determining just compensation is tradi- 
Expropriation long resembled eminent domain in substance; formal similarities followed.

\section{CONCLUSION}

The breadth and complexity of the legal rules used to simulate condemnation seem daunting, yet expropriating an entire continent was, in effect, a business enterprise of massive proportions. Adam Smith marveled at the division of labor in an 18th-century pin factory. ${ }^{497}$ It is unsurprising that the much larger task of taking over an entire continent required an even greater division of labor.

The government coordinated this division of labor. With its customary rule against private purchases of Indian land, reaffirmed in M'Intosh, the state prevented competitive bidding for Indian lands. It drew on a special cadre of career Indian negotiators to buy land cheaply. The government further passed laws to channel the flow of settlers and to regulate their antisocial acts.

In all of these laws, as in Adam Smith's pin factory, the bottom line was the bottom line: acquiring Indian lands at least cost. In this complex enterprise, the means of minimizing cost were not simple. Threats against a formidable foe, while of some use, were often not credible, and so the United States pursued all the negotiating tricks discussed in Part II.B.2 of this Article. Moreover, the nation, whether intentionally or not, benefited from the biological and dietary differences between Indians and settlers, which weakened Indian resistance by spreading disease and thinning game.

The historical record provides strong support for the positive thesis that the desire for cheap land shaped America's Indian policy. That is not to say that it is impossible to make a normative case one way or the other. It is clear, however, that both the benevolent and malevolent schools must craft more sophisticated arguments. Charges of intentional genocide are simply inconsistent with most legal rules governing Indian relations. Conversely, attempts to whitewash everything from the M'Intosh monopsony, to fraud and threats, to seemingly intentional reliance on game-thinning, cannot paint over these dark facts.

tionally a judicial function beyond the legislative power, congressionally determined prices for Indian land are much more akin to a taking than to the negotiated purchases typical in the M'Intosh era.

497 See ADAM SMTTH, AN INQUIRY INTO THE NATURE \& CAUSES OF THE WEALTH OF NATIONS 5 (Edwin Cannan ed., 1937) ("[T]en persons [working in a pin factory], therefore, could make among them upwards of forty-eight thousand pins in a day."). 
Whatever the ultimate normative conclusion, the entire process of expropriating America is a stunning example of Hirschleifer's muscular economics-the "dark side" of efficiency. History is replete with the more obvious forms of expropriation: war and plunder. This Article has shown the wide variety of subtler, yet potent, and certainly cheaper means by which the United States obtained Indian lands "tranquilly, legally, philanthropically, without shedding blood, and without violating a single great principle of morality in the eyes of the world." 